\title{
AFIP-6 Mark II Irradiation Summary Report
}

D. M. Perez

J. W. Nielsen

G. S. Chang

D. M. Wachs

G. A. Roth

N. E. Woolstenhulme

September 2012

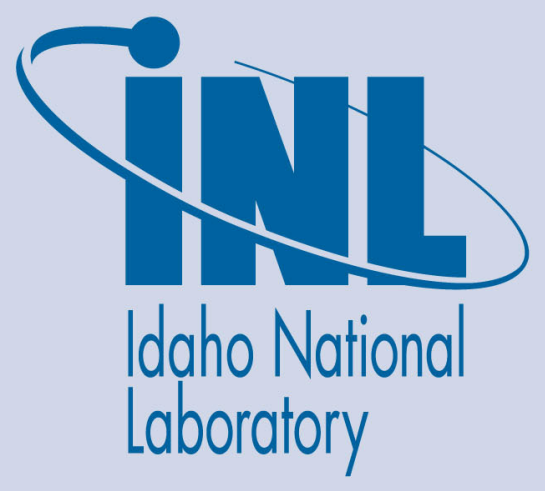

The INL is a U.S. Department of Energy National Laboratory operated by Battelle Energy Alliance 
INL/EXT-12-26305

\title{
AFIP-6 Mark II Irradiation Summary Report
}

\author{
D. M. Perez \\ J.W. Nielsen \\ G. S. Chang \\ D. M. Wachs \\ G. A. Roth
}

N. E. Woolstenhulme

September 2012

\section{Idaho National Laboratory \\ Idaho Falls, Idaho 83415}

http://www.inl.gov

\author{
Prepared for the \\ U.S. Department of Energy \\ Office of National Nuclear Security Administration \\ Under DOE Idaho Operations Office \\ Contract DE-AC07-05ID14517
}




\section{DISCLAIMER}

This information was prepared as an account of work sponsored by an agency of the U.S. Government. Neither the U.S. Government nor any agency thereof, nor any of their employees, makes any warranty, expressed or implied, or assumes any legal liability or responsibility for the accuracy, completeness, or usefulness, of any information, apparatus, product, or process disclosed, or represents that its use would not infringe privately owned rights. References herein to any specific commercial product, process, or service by trade name, trade mark, manufacturer, or otherwise, does not necessarily constitute or imply its endorsement, recommendation, or favoring by the U.S. Government or any agency thereof. The views and opinions of authors expressed herein do not necessarily state or reflect those of the U.S. Government or any agency thereof. 


\title{
AFIP-6 Mark II Irradiation Summary Report
}

\author{
INL/EXT-12-26305
}

September 2012

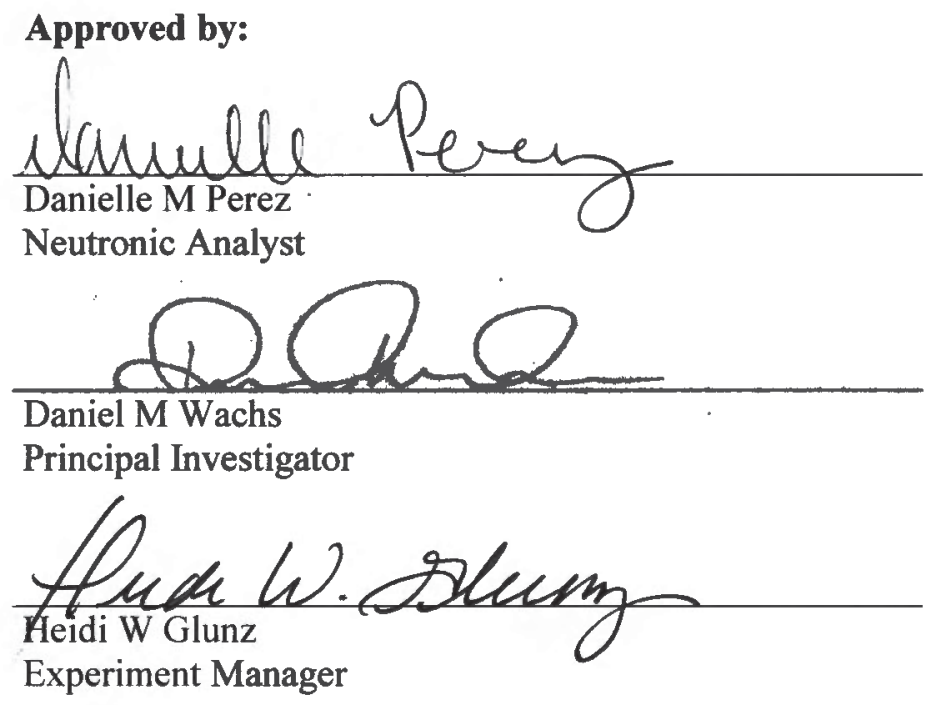




\section{SUMMARY}

Due to the incompletion of the Advanced Test Reactor (ATR) Full size plate In center flux trap Position (AFIP) experiment AFIP-6, a second irradiation (named AFIP-6 Mark II) of identical plates was performed. AFIP-6 Mark II was designed to evaluate high-power large-scale performance of monolithic uranium-molybdenum (U-Mo) fuels ${ }^{1}$.

The following report summarizes the life of the AFIP-6 MKII experiment through end of irradiation, including a brief description of the safety analysis, as-run neutronic analysis results, hydraulic testing results, and thermal analysis results. 


\section{CONTENTS}

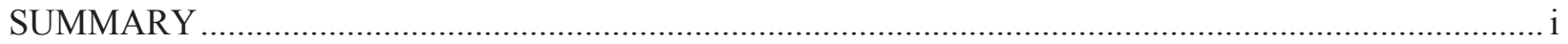

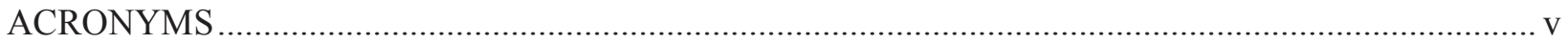

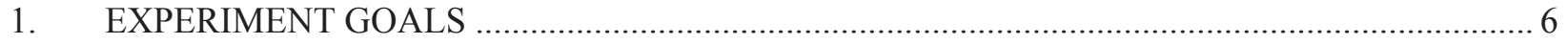

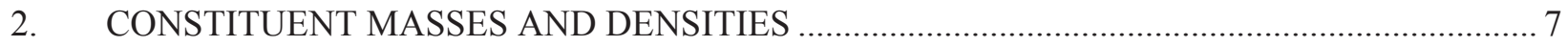

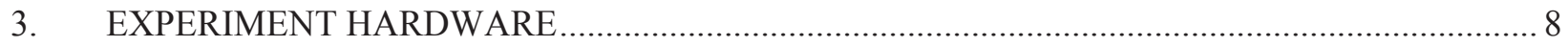

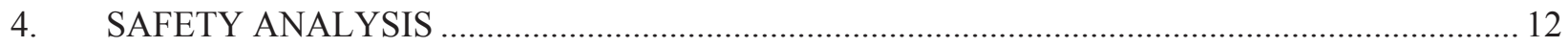

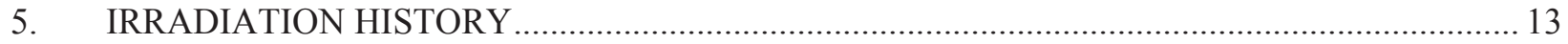

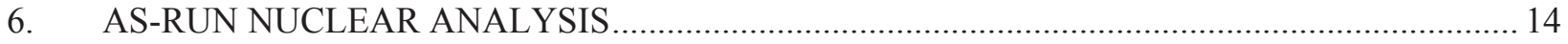

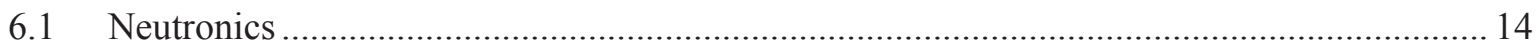

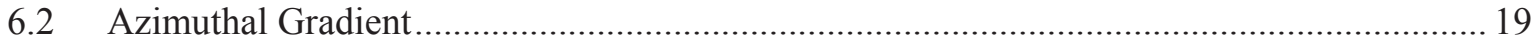

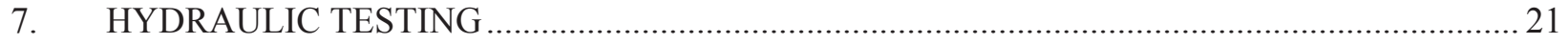

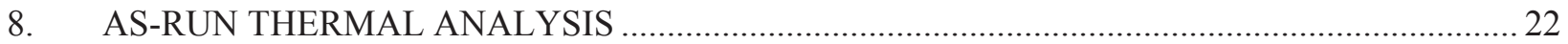

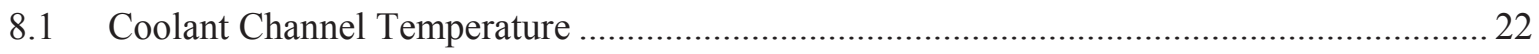

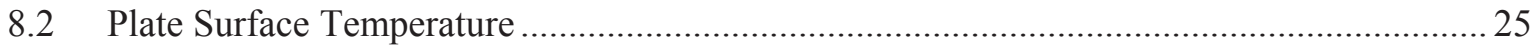

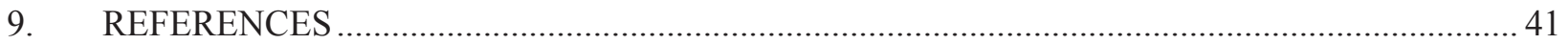

Appendix A: Individual Plate Power and Fission Density Plots........................................................... 42 


\section{FIGURES}

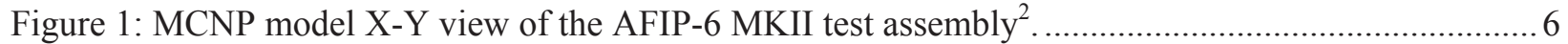

Figure 2: AFIP-6 MKII Test Train Assembly Details. ............................................................................... 9

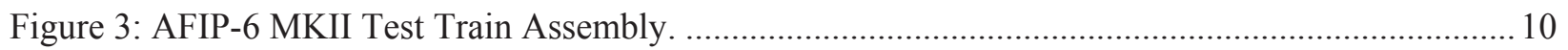

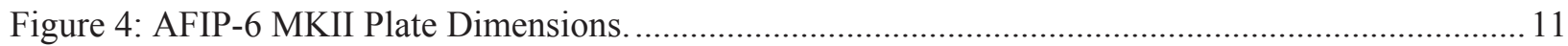

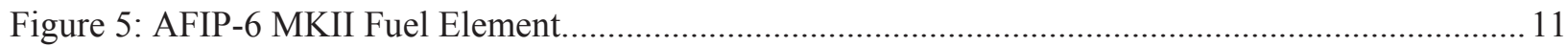

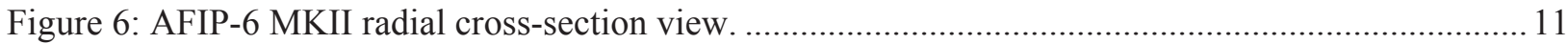

Figure 7: Hourly constrained lobe power history for Cycle 151A...................................................... 13

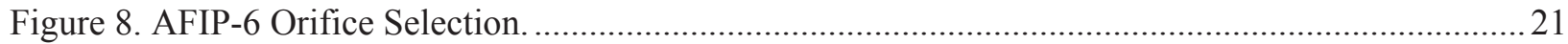

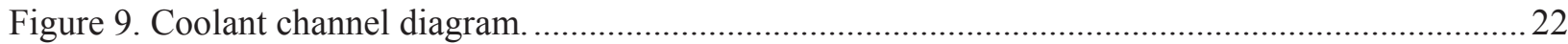

Figure 10: Coolant channel temperatures as a function of location along the AFIP-6 MKII test

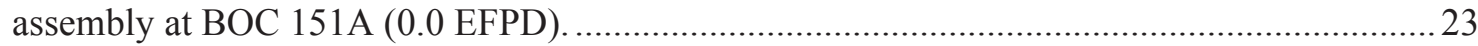

Figure 11: Coolant channel temperatures as a function of location along the AFIP-6 MKII test

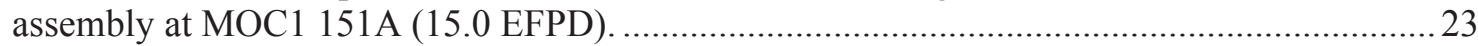

Figure 12: Coolant channel temperatures as a function of location along the AFIP-6 MKII test

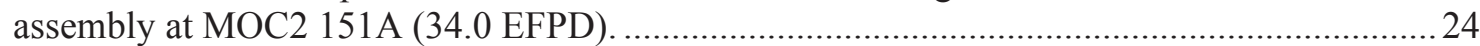

Figure 13: Coolant channel temperatures as a function of location along the AFIP-6 MKII test assembly at EOC 151A (56.1 EFPD). 


\section{TABLES}

Table 1: Experiment matrix for AFIP-6 MKII with as-built enrichments. ................................................. 7

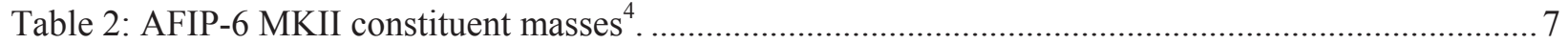

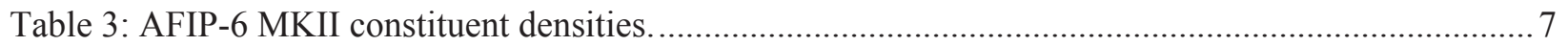

Table 4. AFIP-6 MKII Irradiation Hardware Drawing List...................................................................... 8

Table 5: Summary table of the safety analyses done for the AFIP-6 MKII experiment............................ 12

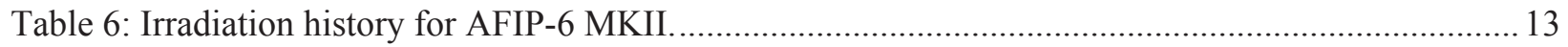

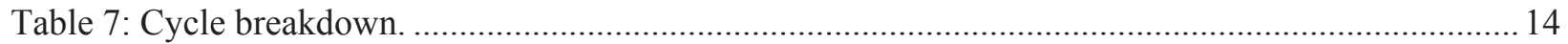

Table 8: Cycle 151A, MCNP-Calculated HGRs and Neutron Flux for AFIP-6 MKII, Plate 6II-1,

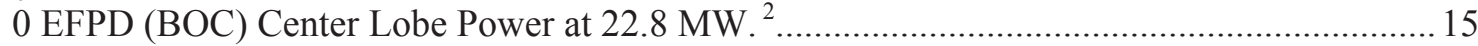

Table 9: Cycle 151A, MCNP-Calculated HGRs, Neutron Flux, Depletion and Fission Density for AFIP-6 MKII, Plate 6II-1, 15 EFPD (MOC1) Center Lobe Power at 21.7 MW. ${ }^{2}$..................... 16

Table 10: Cycle 151A, MCNP-Calculated HGRs, Neutron Flux, Depletion and Fission Density for AFIP-6 MKII, Plate 6II-1, 34 EFPD (MOC2) Center Lobe Power at 22.5 MW. ${ }^{2}$

Table 11: Cycle 151A, MCNP-Calculated HGRs, Neutron Flux, Depletion and Fission Density for AFIP-6 MKII, Plate 6II-1, 56.1 EFPD (EOC) Center Lobe Power at 23.9 MW. ${ }^{2}$.............. 18

Table 12. Azimuthal L2AR for the AFIP-6 MKII Plate 6II-1 at BOC 151A. .......................................... 19

Table 13. AFIP irradiation vehicle flow conditions for each orifice configuration ${ }^{5}$...............................2

Table 14. Plate surface temperatures (Celsius) on the North side of plate 6II-1 in plate position A

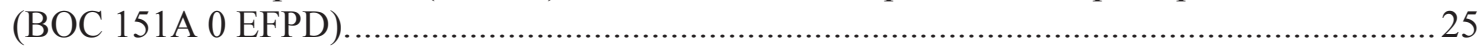

Table 15. Plate surface temperatures (Celsius) on the South side of plate 6II-1 in plate position A

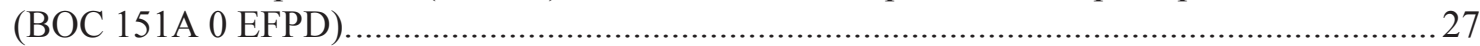

Table 16. Plate surface temperatures (Celsius) on the North side of plate 6II-1 in plate position A (MOC1 151A 15 EFPD).

Table 17. Plate surface temperatures (Celsius) on the South side of plate 6II-1 in plate position A (MOC1 151A 15 EFPD).

Table 18. Plate surface temperatures (Celsius) on the North side of plate 6II-1 in plate position A (MOC2 151A 34 EFPD).

Table 19. Plate surface temperatures (Celsius) on the South side of plate 6II-1 in plate position A (MOC2 151A 34 EFPD).

Table 20. Plate surface temperatures (Celsius) on the North side of plate 6II-1 in plate position A (EOC 151A 56.1 EFPD).

Table 21. Plate surface temperatures (Celsius) on the South side of plate 6II-1 in plate position A (EOC 151A 56.1 EFPD). 


\section{ACRONYMS}

$\begin{array}{ll}\text { Al } & \text { Aluminum } \\ \text { ATR } & \text { Advanced Test Reactor } \\ \text { AFIP } & \text { ATR Full-size plate In center flux trap Position } \\ \text { CFT } & \text { Center Flux Trap } \\ \text { DAS } & \text { Data Acquisition System } \\ \text { EFPD } & \text { Effective Full Power Days } \\ \text { GTRI } & \text { Global Threat Reduction Initiative } \\ \text { FD } & \text { Fuel Development } \\ \text { HIP } & \text { Hot Isostatic Pressing } \\ \text { MCNP } & \text { Monte Carlo N-Particle } \\ \text { Mo } & \text { Molybdenum } \\ \text { RERTR } & \text { Reduced Enrichment Research and Test Reactor } \\ \text { U } & \text { Uranium } \\ \text { U-Mo } & \text { Uranium-Molybdenum } \\ \text { Zr } & \text { Zirconium }\end{array}$




\section{AFIP-6 Mark II Irradiation Summary Report \\ 1. EXPERIMENT GOALS}

In support of the Global Threat Reduction Initiative (GTRI) Fuel Development (FD) program (historically known as Reduced Enrichment for Research and Test Reactors [RERTR]), the Advanced Test Reactor (ATR) Full size plate In center flux trap Position (AFIP) experiment AFIP-6 Mark II (referred to as AFIP6 MKII throughout this report) was designed to evaluate high-power large-scale performance of monolithic uranium-molybdenum (U-Mo) fuels ${ }^{1}$.

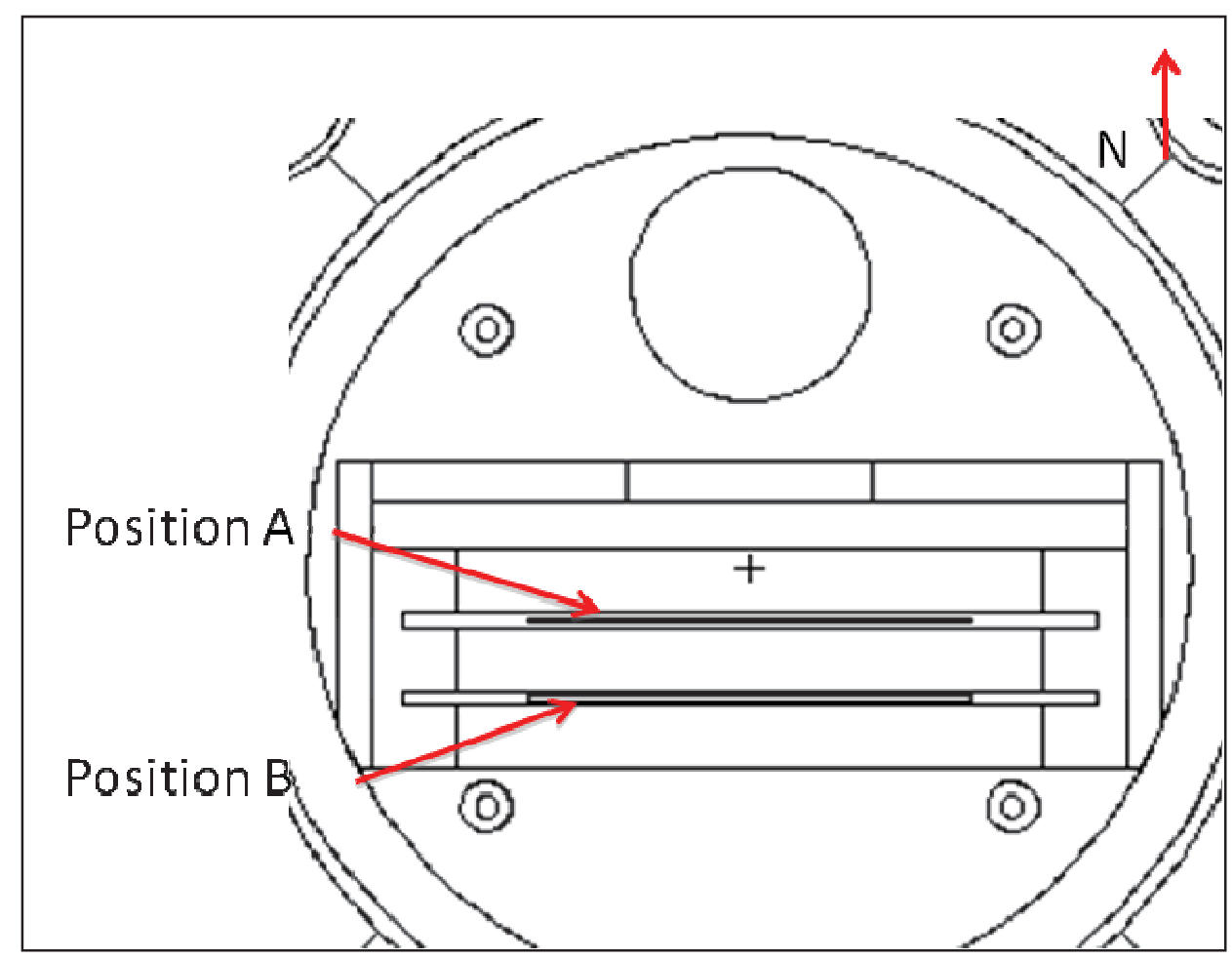

Figure 1: MCNP model X-Y view of the AFIP-6 MKII test assembly².

The AFIP-6 MKII experiment was irradiated in the ATR Center Flux Trap (CFT) position. The test assembly was designed to hold 2 full length fuel plates. Each plate is approximately 45 in. in length, $2.235 \mathrm{in}$. in width and $0.050 \mathrm{in}$. in thickness. The fuel zone was nominally $22.50 \mathrm{in}$. in length, $1.375 \mathrm{in}$. in width and 0.013 in. in thickness. A diffusion barrier of $\sim 0.001$ in. thick zirconium was bonded to the top and bottom surface of the fuel foil.

The AFIP-6 MKII experiment was originally designed to irradiate two plates, one plate was to be irradiated for two cycles and the other plate was to be irradiated for one cycle (such that the last cycle contained both plates). Due to structural challenges with a non-fueled component of the assembly, the AFIP-6 MKII experiment was pulled from the reactor resulting in the irradiation of only one plate for one cycle $^{3}$. The original designed experiment matrix is shown in Table 1. 
Table 1: Experiment matrix for AFIP-6 MKII with as-built enrichments.

\begin{tabular}{|c|c|}
\hline \multicolumn{2}{|c|}{$\begin{array}{c}\text { AFIP-6 MKII Experiment } \\
\text { Matrix }\end{array}$} \\
\hline $\begin{array}{c}\text { Plate } \\
\text { Position A }\end{array}$ & $\begin{array}{c}\text { U-10 Mo } \\
\text { 6II-1 } \\
\text { Plate }\end{array}$ \\
$\begin{array}{c}\text { U-10 Mo } \\
\text { Position B }\end{array}$ & $\begin{array}{c}40.01 \% \text { enrich. } \\
\text { 6II-2 }\end{array}$ \\
\hline
\end{tabular}

\section{CONSTITUENT MASSES AND DENSITIES}

The constituent masses and densities for the 2 plates were obtained from the as-built data package plate $^{4}$ summary sheets. Table 2 summarizes the constituent masses for the plates and Table 3 summarizes the constituent densities for the plates.

Table 2: AFIP-6 MKII constituent masses ${ }^{4}$.

\begin{tabular}{|c|c|c|c|c|c|c|}
\hline $\begin{array}{c}\text { Fuel Plate } \\
\text { Location }\end{array}$ & $\begin{array}{c}\text { Fuel Plate } \\
\text { ID }\end{array}$ & $\begin{array}{c}\text { Total-U } \\
(\mathrm{g})\end{array}$ & $\begin{array}{c}\mathrm{U}-238 \\
(\mathrm{~g})\end{array}$ & $\begin{array}{c}\mathrm{U}-235 \\
(\mathrm{~g})\end{array}$ & $\begin{array}{c}\text { Mo } \\
(\mathrm{g})\end{array}$ & $\begin{array}{c}\mathrm{Zr} \\
(\mathrm{g})\end{array}$ \\
\hline $\mathrm{A}$ & $6 \mathrm{II}-1$ & 100.96 & 60.93 & 40.38 & 11.22 & 6.62 \\
\hline $\mathrm{B}$ & $6 \mathrm{II}-2$ & 102.33 & 60.81 & 40.94 & 11.17 & 5.66 \\
\hline
\end{tabular}

Table 3: AFIP-6 MKII constituent densities.

\begin{tabular}{|c|c|c|c|c|c|c||c|c|}
\hline \multirow{2}{*}{$\begin{array}{c}\text { Fuel Plate } \\
\text { Location }\end{array}$} & $\begin{array}{c}\text { Fuel } \\
\text { Plate ID }\end{array}$ & $\begin{array}{c}\text { Volume } \\
(\mathrm{cc})\end{array}$ & $\begin{array}{c}\text { Total-U } \\
(\mathrm{g} / \mathrm{cc})\end{array}$ & $\begin{array}{c}\mathrm{U}-238 \\
(\mathrm{~g} / \mathrm{cc})\end{array}$ & $\begin{array}{c}\mathrm{U}-235 \\
(\mathrm{~g} / \mathrm{cc})\end{array}$ & $\begin{array}{c}\text { Mo } \\
(\mathrm{g} / \mathrm{cc})\end{array}$ & $\begin{array}{c}\text { Volume } \\
(\mathrm{cc})\end{array}$ & $\begin{array}{c}\mathrm{Zr} \\
(\mathrm{g} / \mathrm{cc})\end{array}$ \\
\hline A & $6 \mathrm{II}-1$ & 6.59 & 15.32 & 9.24 & 6.13 & 1.70 & 1.01 & 6.53 \\
\hline B & $6 \mathrm{II}-2$ & 6.59 & 15.53 & 9.23 & 6.21 & 1.70 & 1.01 & 5.58 \\
\hline
\end{tabular}




\section{EXPERIMENT HARDWARE}

The experiment hardware list for AFIP-6 MKII is shown in Table 4. The assembly retriever used for AFIP-1, $-2,-3,-4$ and -6 was also used for AFIP-6 MKII a new holder was designed to accommodate the new orifice design.

Table 4. AFIP-6 MKII Irradiation Hardware Drawing List.

\begin{tabular}{c|c}
\hline Drawing Number & Drawing Title \\
\hline 635792, Rev 3 & ATR Full Size Plate in Center Flux Trap Position (AFIP) Plate Holder \\
Tube Assembly and Details
\end{tabular}

The AFIP-6 MKII test train assembly as shown in Figure 2 shows the main components of the test assembly, which includes the fuel plate assembly. Figure 3 shows the test train assembly with the retriever attached to the top. The retriever is used to get the test train assembly out of the reactor. Figure 4 has the specific fuel plate dimensions and nominal fuel foil dimensions. Figure 5 depicts the fuel element and Figure 6 is a radial cross section of the test train assembly and shows the locations of all the components. 

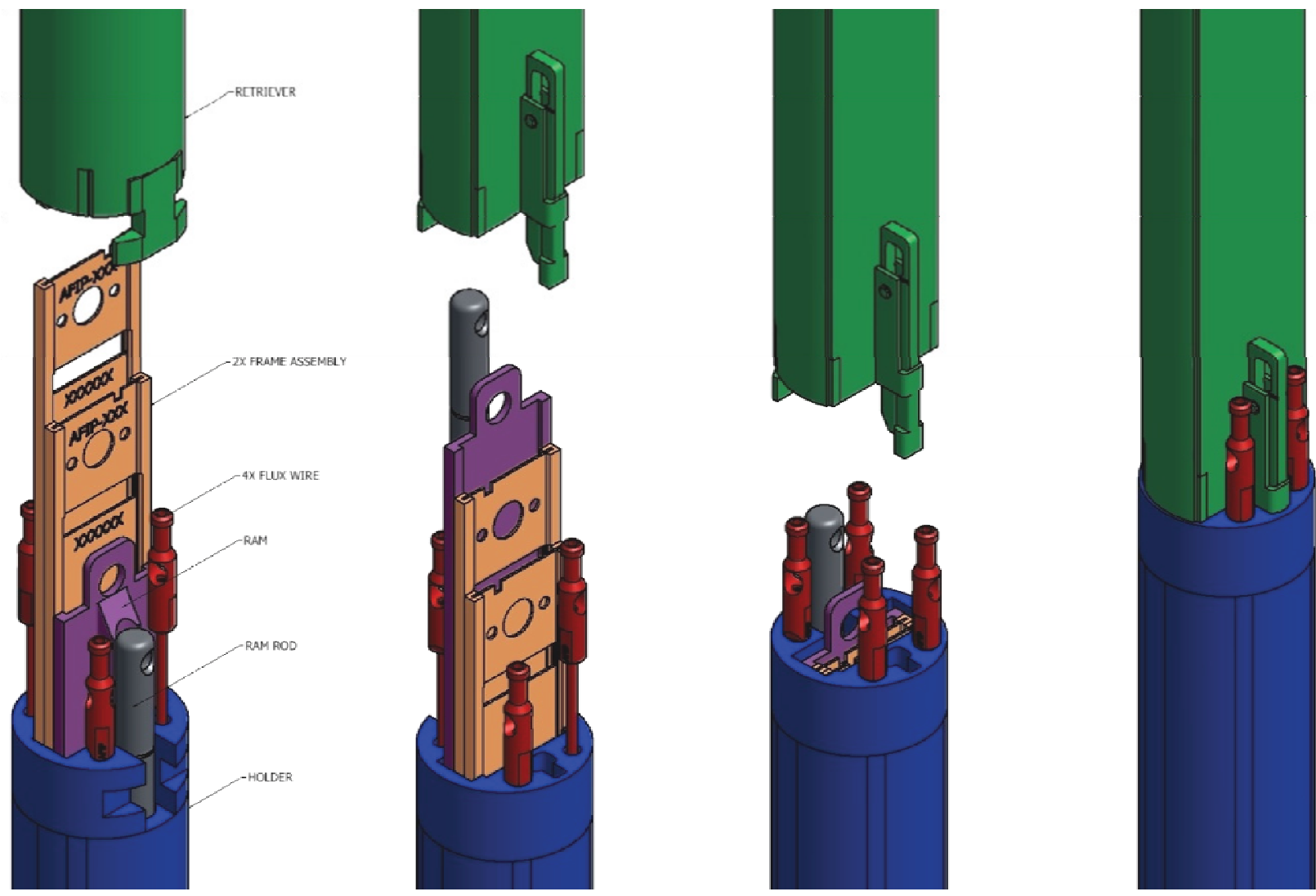

Figure 2: AFIP-6 MKII Test Train Assembly Details. 


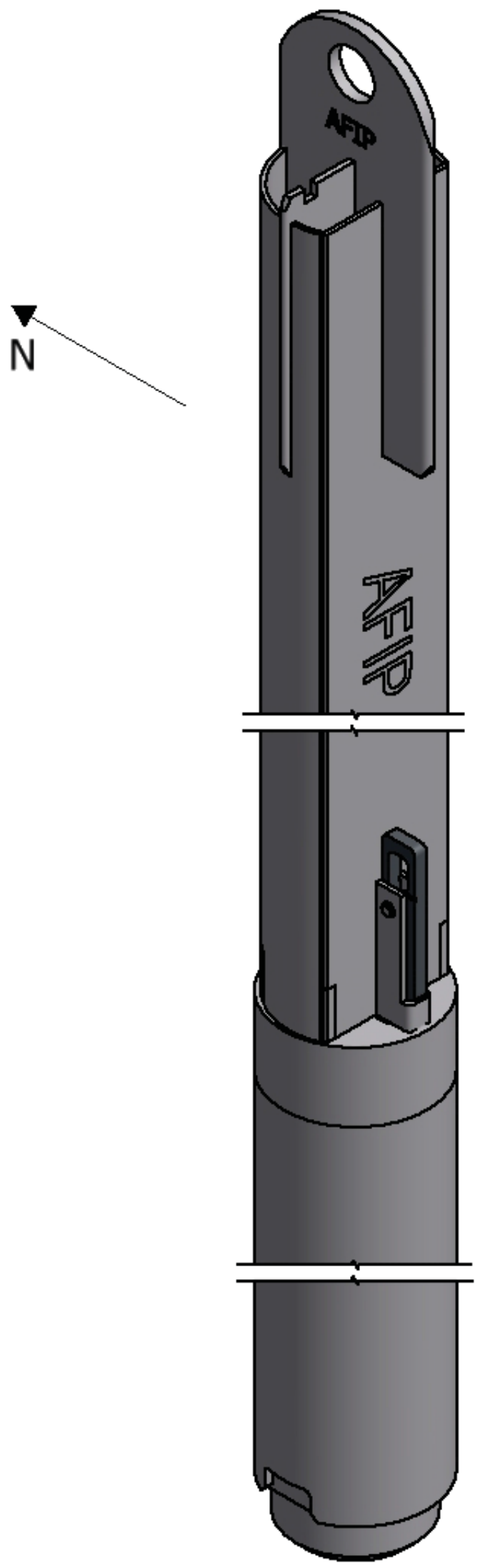

Figure 3: AFIP-6 MKII Test Train Assembly. 


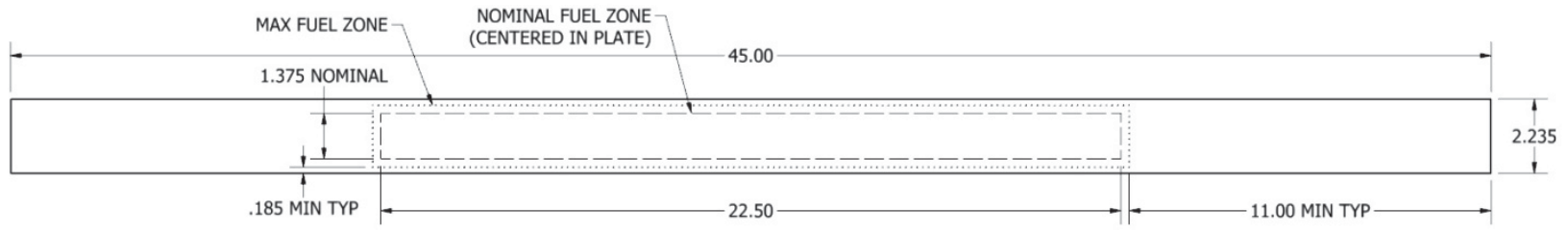

Figure 4: AFIP-6 MKII Plate Dimensions.

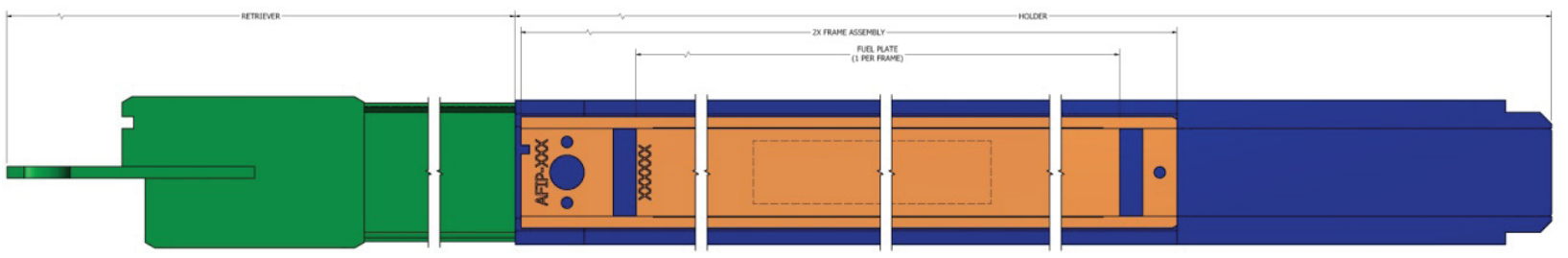

Figure 5: AFIP-6 MKII Fuel Element.

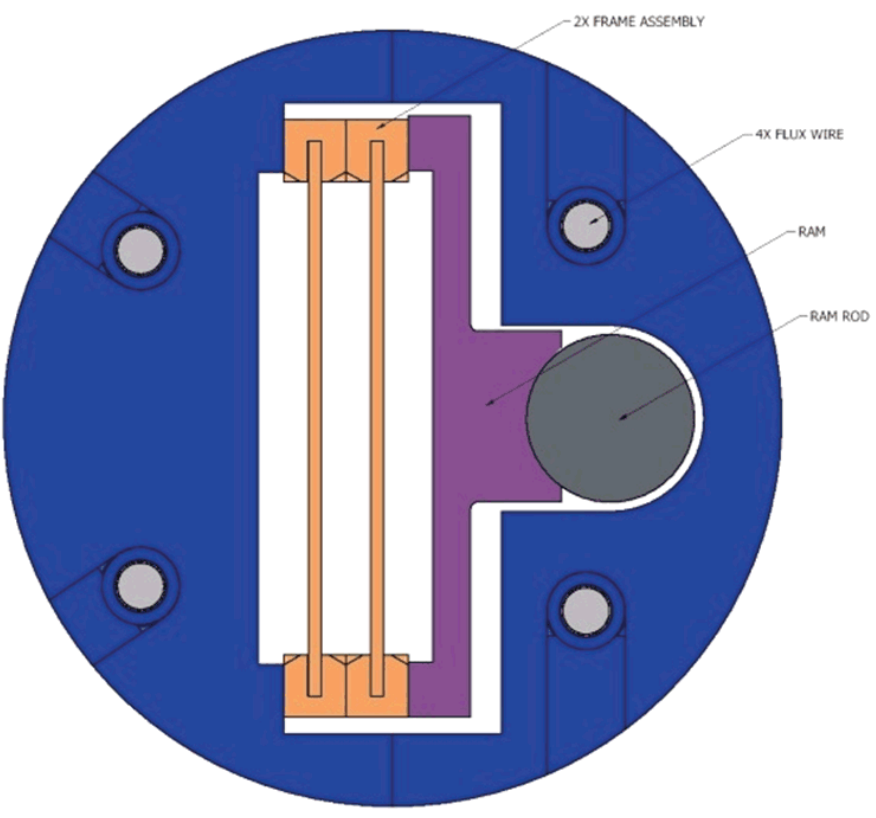

Figure 6: AFIP-6 MKII radial cross-section view. 


\section{SAFETY ANALYSIS}

The safety analysis that was performed on the AFIP-6 MKII experiment includes thermal/hydraulic analysis, physics analysis, and structural analysis. Table 5 summarizes the safety analyses performed on the AFIP-6 MKII experiment.

Table 5: Summary table of the safety analyses done for the AFIP-6 MKII experiment.

\begin{tabular}{c|l}
\multicolumn{1}{c}{ ECAR Number } & \multicolumn{1}{c}{ Description } \\
\hline ECAR-1577 & $\begin{array}{l}\text { ATR Physics Analysis of the AFIP-6 MKII Experiment in the } \\
\text { Center Flux Trap }\end{array}$ \\
\hline ECAR-1568 & AFIP-6 MKII Test Train Structural Evaluations in ATR \\
\hline ECAR-1641 & AFIP-6 MKII Thermal Analysis \\
\hline ECAR-121 & Total Flow Evaluations for AFIP and Backups \\
\hline ECAR-981 & AFIP Half-Inch Backup Thermal Analysis \\
\hline
\end{tabular}




\section{IRRADIATION HISTORY}

The AFIP-6 MKII test assembly was irradiated during cycle151A in the ATR Center Flux Trap (CFT). Cycle 151A ran for 56.1 effective full power days (EFPDs) with an average center lobe power of 22.0 MW (total core average power of $101.7 \mathrm{MW}$ ). There was 1 mid-cycle scram with duration 3 days from $12 / 25 / 2011-12 / 28 / 2011$. This information is summarized in Table 6.

Table 6: Irradiation history for AFIP-6 MKII.

\begin{tabular}{|c|c|c|c|c|c|c|c|}
\hline $\begin{array}{c}\text { ATR } \\
\text { CYCLE }\end{array}$ & $\begin{array}{l}\text { AFIP } \\
\text { Test ID }\end{array}$ & $\begin{array}{c}\text { Dates } \\
\text { Irradiated }\end{array}$ & $\begin{array}{l}\text { Cycle } \\
\text { EFPDs }\end{array}$ & $\begin{array}{c}\text { Mid-Cycle } \\
\text { Scram } \\
\text { Decay } \\
\text { Days }\end{array}$ & $\begin{array}{c}\text { Post-Cycle } \\
\text { Decay } \\
\text { Days }\end{array}$ & $\begin{array}{c}\text { Center } \\
\text { Flux } \\
\text { Trap } \\
\text { Power } \\
\text { (MW) }\end{array}$ & $\begin{array}{l}\text { Total } \\
\text { Core } \\
\text { Power } \\
(\mathrm{MW}) \\
\end{array}$ \\
\hline $151 \mathrm{~A}$ & $\begin{array}{c}\text { AFIP-6 } \\
\text { MKII }\end{array}$ & $\begin{array}{c}12 / 14 / 2011- \\
02 / 11 / 2012\end{array}$ & 56.1 & 3 & 19 & 22.0 & 101.7 \\
\hline
\end{tabular}

The hourly power history for cycle 151A is obtained as an ATR Surveillance Report from the ATR Data Acquisition System (DAS). The plot of each lobe power on an hourly basis is shown in Figure 7.

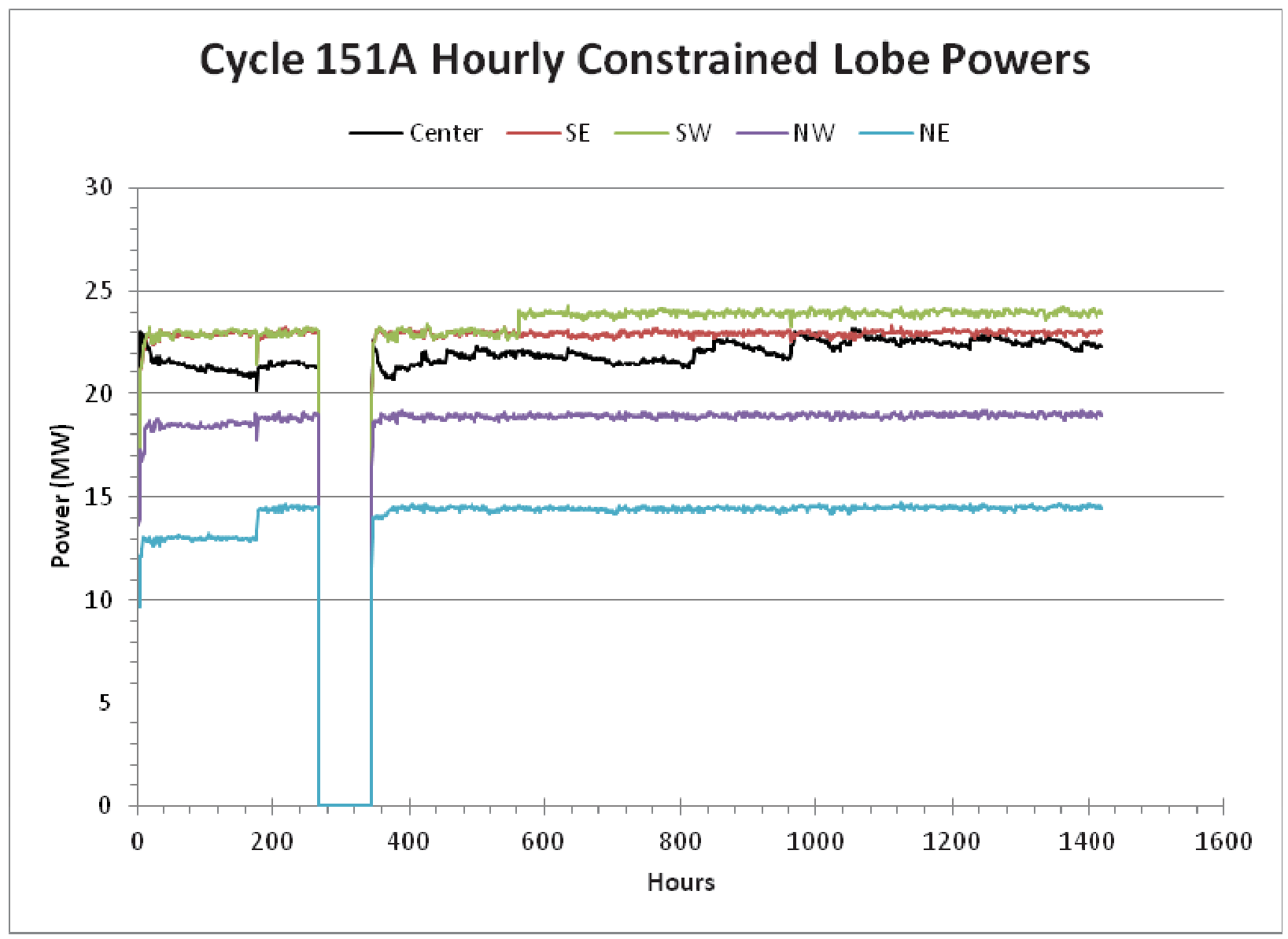

Figure 7: Hourly constrained lobe power history for Cycle 151A. 


\section{AS-RUN NUCLEAR ANALYSIS}

\subsection{Neutronics}

The as-run calculations were performed using the irradiation history in Table 6, the Monte Carlo N-Particle (MCNP) code, ORIGEN2.2 and $\mathrm{MCWO}^{2}$. The calculated as-run fission heat rates, fission densities, and as-run U-235 burnup results for the fueled plates reported have an uncertainty band $(1 \sigma)$ of $2.5 \%{ }^{2}$. The time intervals used to calculate the average plate power and burnup is shown in Table 7.

\begin{tabular}{cc}
\multicolumn{2}{c}{ Table 7: Cycle breakdown. } \\
\hline $\begin{array}{c}\text { Time } \\
\text { Interval }\end{array}$ & $\begin{array}{c}151 \mathrm{~A} \\
\text { (days) }\end{array}$ \\
\hline BOC & 0.0 \\
MOC 1 & 15.0 \\
MOC 2 & 19.0 \\
EOC & 22.1 \\
\hline Total EFPDs & 56.1 \\
\hline \hline Cumulative & 56.1 \\
\hline
\end{tabular}

The MCNP-calculated plate power and burnup for the time intervals for each cycle are shown in Table 8 through Table 11 . The plots of the fission power density and fission density as a function of the ATR Cycle time interval are in Appendix A. 
Table 8: Cycle 151A, MCNP-Calculated HGRs and Neutron Flux for AFIP-6 MKII, Plate 6II-1, 0 EFPD (BOC) Center Lobe Power at 22.8 MW. ${ }^{2}$

\begin{tabular}{|c|c|c|c|c|}
\hline Node & $\begin{array}{l}\text { Distance from } \\
\text { Centerline } \\
\text { (in.) }\end{array}$ & $\begin{array}{c}\text { Fission Power } \\
\text { Density } \\
\text { (W/cc) }\end{array}$ & $\begin{array}{c}\text { Surface } \\
\text { Heat Flux } \\
\left(\mathrm{W} / \mathrm{cm}^{2}\right) \\
\end{array}$ & $\begin{array}{c}\text { Neutron } \\
\text { Flux } \\
\left(\mathrm{n} / \mathrm{cm}^{2} \mathrm{sec}\right) \\
\end{array}$ \\
\hline 1 & 11 & 29760.15 & 491.34 & $9.59 \mathrm{E}+14$ \\
\hline 2 & 10.5 & 28295.36 & 467.16 & $9.84 \mathrm{E}+14$ \\
\hline 3 & 10 & 28736.31 & 474.44 & $1.00 \mathrm{E}+15$ \\
\hline 4 & 9.5 & 29046.13 & 479.55 & $1.01 \mathrm{E}+15$ \\
\hline 5 & 9 & 29723.63 & 490.74 & $1.04 \mathrm{E}+15$ \\
\hline 6 & 8.5 & 30380.47 & 501.58 & $1.05 \mathrm{E}+15$ \\
\hline 7 & 8 & 30636.54 & 505.81 & $1.06 \mathrm{E}+15$ \\
\hline 8 & 7.5 & 31289.00 & 516.58 & $1.09 \mathrm{E}+15$ \\
\hline 9 & 7 & 31612.15 & 521.92 & $1.09 \mathrm{E}+15$ \\
\hline 10 & 6.5 & 31813.56 & 525.24 & $1.10 \mathrm{E}+15$ \\
\hline 11 & 6 & 32087.32 & 529.76 & $1.12 \mathrm{E}+15$ \\
\hline 13 & 5.5 & 32407.15 & 535.04 & $1.13 \mathrm{E}+15$ \\
\hline 14 & 5 & 32448.26 & 535.72 & $1.13 \mathrm{E}+15$ \\
\hline 15 & 4.5 & 32567.71 & 537.69 & $1.13 \mathrm{E}+15$ \\
\hline 16 & 4 & 33024.34 & 545.23 & $1.14 \mathrm{E}+15$ \\
\hline 17 & 3.5 & 33024.80 & 545.24 & $1.15 \mathrm{E}+15$ \\
\hline 18 & 3 & 33482.58 & 552.80 & $1.16 \mathrm{E}+15$ \\
\hline 19 & 2.5 & 33344.99 & 550.53 & $1.16 \mathrm{E}+15$ \\
\hline 20 & 2 & 33904.99 & 559.77 & $1.17 \mathrm{E}+15$ \\
\hline 21 & 1.5 & 34385.51 & 567.70 & $1.17 \mathrm{E}+15$ \\
\hline 22 & 1 & 33815.99 & 558.30 & $1.18 \mathrm{E}+15$ \\
\hline 23 & 0.5 & 34134.99 & 563.57 & $1.17 \mathrm{E}+15$ \\
\hline 24 & 0 & 34639.55 & 571.90 & $1.17 \mathrm{E}+15$ \\
\hline 25 & -0.5 & 34120.44 & 563.33 & $1.18 \mathrm{E}+15$ \\
\hline 26 & -1 & 33798.31 & 558.01 & $1.17 \mathrm{E}+15$ \\
\hline 27 & -1.5 & 34231.91 & 565.17 & $1.18 \mathrm{E}+15$ \\
\hline 28 & -2 & 34396.07 & 567.88 & $1.18 \mathrm{E}+15$ \\
\hline 29 & -2.5 & 34146.63 & 563.76 & $1.17 \mathrm{E}+15$ \\
\hline 30 & -3 & 33997.65 & 561.30 & $1.17 \mathrm{E}+15$ \\
\hline 31 & -3.5 & 34167.07 & 564.10 & $1.18 \mathrm{E}+15$ \\
\hline 32 & -4 & 34117.54 & 563.28 & $1.17 \mathrm{E}+15$ \\
\hline 33 & -4.5 & 33628.44 & 555.21 & $1.16 \mathrm{E}+15$ \\
\hline 34 & -5 & 33138.04 & 547.11 & $1.16 \mathrm{E}+15$ \\
\hline 35 & -5.5 & 33487.86 & 552.88 & $1.15 \mathrm{E}+15$ \\
\hline 36 & -6 & 32776.77 & 541.14 & $1.14 \mathrm{E}+15$ \\
\hline 37 & -6.5 & 33280.65 & 549.46 & $1.14 \mathrm{E}+15$ \\
\hline 38 & -7 & 32834.64 & 542.10 & $1.13 \mathrm{E}+15$ \\
\hline 39 & -7.5 & 32509.59 & 536.73 & $1.11 \mathrm{E}+15$ \\
\hline 40 & -8 & 32120.95 & 530.32 & $1.11 \mathrm{E}+15$ \\
\hline 41 & -8.5 & 31768.83 & 524.50 & $1.09 \mathrm{E}+15$ \\
\hline 42 & -9 & 32030.59 & 528.83 & $1.08 \mathrm{E}+15$ \\
\hline 43 & -9.5 & 30717.98 & 507.15 & $1.07 \mathrm{E}+15$ \\
\hline 44 & -10 & 30332.55 & 500.79 & $1.05 \mathrm{E}+15$ \\
\hline 45 & -10.5 & 30263.80 & 499.66 & $1.03 \mathrm{E}+15$ \\
\hline
\end{tabular}


Table 9: Cycle 151A, MCNP-Calculated HGRs, Neutron Flux, Depletion and Fission Density for AFIP-6 MKII, Plate 6II-1, 15 EFPD (MOC1) Center Lobe Power at 21.7 MW. ${ }^{2}$

\begin{tabular}{|c|c|c|c|c|c|c|}
\hline Node & $\begin{array}{l}\text { Distance from } \\
\text { Centerline } \\
\text { (in.) }\end{array}$ & $\begin{array}{c}\text { Fission Power } \\
\text { Density } \\
(W / c c)\end{array}$ & $\begin{array}{l}\text { Surface } \\
\text { Heat Flux } \\
\left(\mathrm{W} / \mathrm{cm}^{2}\right)\end{array}$ & $\begin{array}{c}\text { Neutron } \\
\text { Flux } \\
\left(\mathbf{n} / \mathrm{cm}^{2} \mathrm{sec}\right)\end{array}$ & $\begin{array}{c}\text { Fission } \\
\text { Density } \\
\text { (fissions/ce) }\end{array}$ & $\begin{array}{c}\text { U-235 } \\
\text { Burnup } \\
(\%)\end{array}$ \\
\hline 1 & 11 & 21159.51 & 349.34 & $8.40 \mathrm{E}+14$ & $1.23 \mathrm{E}+21$ & $8.88 \%$ \\
\hline 2 & 10.5 & 19799.87 & 326.90 & $8.51 \mathrm{E}+14$ & $1.17 \mathrm{E}+21$ & $8.44 \%$ \\
\hline 3 & 10 & 20119.01 & 332.16 & $8.68 \mathrm{E}+14$ & $1.19 \mathrm{E}+21$ & $8.63 \%$ \\
\hline 4 & 9.5 & 20531.57 & 338.98 & $8.83 \mathrm{E}+14$ & $1.20 \mathrm{E}+21$ & $8.70 \%$ \\
\hline 5 & 9 & 20193.86 & 333.40 & $8.87 \mathrm{E}+14$ & $1.23 \mathrm{E}+21$ & $8.88 \%$ \\
\hline 6 & 8.5 & 20453.00 & 337.68 & $8.97 \mathrm{E}+14$ & $1.26 \mathrm{E}+21$ & $9.07 \%$ \\
\hline 7 & 8 & 20616.53 & 340.38 & $9.13 \mathrm{E}+14$ & $1.27 \mathrm{E}+21$ & $9.14 \%$ \\
\hline 8 & 7.5 & 20953.06 & 345.94 & $9.22 \mathrm{E}+14$ & $1.29 \mathrm{E}+21$ & $9.33 \%$ \\
\hline 9 & 7 & 21271.48 & 351.19 & $9.22 \mathrm{E}+14$ & $1.31 \mathrm{E}+21$ & $9.45 \%$ \\
\hline 10 & 6.5 & 21114.30 & 348.60 & $9.30 \mathrm{E}+14$ & $1.31 \mathrm{E}+21$ & $9.51 \%$ \\
\hline 11 & 6 & 21347.74 & 352.45 & $9.33 \mathrm{E}+14$ & $1.33 \mathrm{E}+21$ & $9.58 \%$ \\
\hline 13 & 5.5 & 21354.76 & 352.57 & $9.40 \mathrm{E}+14$ & $1.34 \mathrm{E}+21$ & $9.64 \%$ \\
\hline 14 & 5 & 21750.43 & 359.10 & $9.58 \mathrm{E}+14$ & $1.34 \mathrm{E}+21$ & $9.70 \%$ \\
\hline 15 & 4.5 & 21554.46 & 355.86 & $9.42 \mathrm{E}+14$ & $1.35 \mathrm{E}+21$ & $9.70 \%$ \\
\hline 16 & 4 & 21732.56 & 358.80 & $9.53 \mathrm{E}+14$ & $1.36 \mathrm{E}+21$ & $9.83 \%$ \\
\hline 17 & 3.5 & 22164.51 & 365.94 & $9.67 \mathrm{E}+14$ & $1.36 \mathrm{E}+21$ & $9.83 \%$ \\
\hline 18 & 3 & 21935.30 & 362.15 & $9.61 \mathrm{E}+14$ & $1.38 \mathrm{E}+21$ & $9.96 \%$ \\
\hline 19 & 2.5 & 21962.67 & 362.60 & $9.70 \mathrm{E}+14$ & $1.38 \mathrm{E}+21$ & $9.89 \%$ \\
\hline 20 & 2 & 22267.04 & 367.63 & $9.78 \mathrm{E}+14$ & $1.40 \mathrm{E}+21$ & $10.08 \%$ \\
\hline 21 & 1.5 & 21991.35 & 363.08 & $9.63 \mathrm{E}+14$ & $1.42 \mathrm{E}+21$ & $10.21 \%$ \\
\hline 22 & 1 & 22200.73 & 366.53 & $9.76 \mathrm{E}+14$ & $1.40 \mathrm{E}+21$ & $10.08 \%$ \\
\hline 23 & 0.5 & 21937.46 & 362.19 & $9.71 \mathrm{E}+14$ & $1.41 \mathrm{E}+21$ & $10.14 \%$ \\
\hline 24 & 0 & 22012.28 & 363.42 & $9.65 \mathrm{E}+14$ & $1.43 \mathrm{E}+21$ & $10.27 \%$ \\
\hline 25 & -0.5 & 22009.23 & 363.37 & $9.79 \mathrm{E}+14$ & $1.41 \mathrm{E}+21$ & $10.14 \%$ \\
\hline 26 & -1 & 22021.14 & 363.57 & $9.77 \mathrm{E}+14$ & $1.40 \mathrm{E}+21$ & $10.02 \%$ \\
\hline 27 & -1.5 & 21880.17 & 361.24 & $9.76 \mathrm{E}+14$ & $1.41 \mathrm{E}+21$ & $10.14 \%$ \\
\hline 28 & -2 & 22433.17 & 370.37 & $9.79 \mathrm{E}+14$ & $1.42 \mathrm{E}+21$ & $10.21 \%$ \\
\hline 29 & -2.5 & 22074.61 & 364.45 & $9.61 \mathrm{E}+14$ & $1.41 \mathrm{E}+21$ & $10.14 \%$ \\
\hline 30 & -3 & 22262.93 & 367.56 & $9.70 \mathrm{E}+14$ & $1.41 \mathrm{E}+21$ & $10.08 \%$ \\
\hline 31 & -3.5 & 22189.44 & 366.35 & $9.71 \mathrm{E}+14$ & $1.41 \mathrm{E}+21$ & $10.14 \%$ \\
\hline 32 & -4 & 22402.36 & 369.86 & $9.74 \mathrm{E}+14$ & $1.41 \mathrm{E}+21$ & $10.14 \%$ \\
\hline 33 & -4.5 & 21890.66 & 361.41 & $9.64 \mathrm{E}+14$ & $1.39 \mathrm{E}+21$ & $9.96 \%$ \\
\hline 34 & -5 & 21891.43 & 361.43 & $9.62 \mathrm{E}+14$ & $1.37 \mathrm{E}+21$ & $9.89 \%$ \\
\hline 35 & -5.5 & 21663.97 & 357.67 & $9.52 \mathrm{E}+14$ & $1.38 \mathrm{E}+21$ & $9.96 \%$ \\
\hline 36 & -6 & 21910.82 & 361.75 & $9.55 \mathrm{E}+14$ & $1.35 \mathrm{E}+21$ & $9.77 \%$ \\
\hline 37 & -6.5 & 21839.81 & 360.58 & $9.47 \mathrm{E}+14$ & $1.38 \mathrm{E}+21$ & $9.89 \%$ \\
\hline 38 & -7 & 21553.84 & 355.85 & $9.44 \mathrm{E}+14$ & $1.36 \mathrm{E}+21$ & $9.77 \%$ \\
\hline 39 & -7.5 & 21195.11 & 349.93 & $9.34 \mathrm{E}+14$ & $1.34 \mathrm{E}+21$ & $9.70 \%$ \\
\hline 40 & -8 & 21321.53 & 352.02 & $9.29 \mathrm{E}+14$ & $1.33 \mathrm{E}+21$ & $9.58 \%$ \\
\hline 41 & -8.5 & 21245.98 & 350.77 & $9.21 \mathrm{E}+14$ & $1.31 \mathrm{E}+21$ & $9.51 \%$ \\
\hline 42 & -9 & 21304.29 & 351.73 & $9.21 \mathrm{E}+14$ & $1.32 \mathrm{E}+21$ & $9.51 \%$ \\
\hline 43 & -9.5 & 20849.74 & 344.23 & $9.02 \mathrm{E}+14$ & $1.27 \mathrm{E}+21$ & $9.20 \%$ \\
\hline 44 & -10 & 21054.61 & 347.61 & $8.97 \mathrm{E}+14$ & $1.25 \mathrm{E}+21$ & $9.07 \%$ \\
\hline 45 & -10.5 & 20979.90 & 346.38 & $8.86 \mathrm{E}+14$ & $1.25 \mathrm{E}+21$ & $9.01 \%$ \\
\hline
\end{tabular}


Table 10: Cycle 151A, MCNP-Calculated HGRs, Neutron Flux, Depletion and Fission Density for AFIP-6 MKII, Plate 6II-1, 34 EFPD (MOC2) Center Lobe Power at 22.5 MW. ${ }^{2}$

\begin{tabular}{|c|c|c|c|c|c|c|}
\hline Node & $\begin{array}{l}\text { Distance from } \\
\text { Centerline } \\
\text { (in.) }\end{array}$ & $\begin{array}{c}\text { Fission Power } \\
\text { Density } \\
\text { (W/cc) }\end{array}$ & $\begin{array}{c}\text { Surface } \\
\text { Heat Flux } \\
\left(W / \mathrm{cm}^{2}\right)\end{array}$ & $\begin{array}{c}\text { Neutron } \\
\text { Flux } \\
\left(\mathbf{n} / \mathrm{cm}^{2} \mathrm{sec}\right)\end{array}$ & $\begin{array}{c}\text { Fission } \\
\text { Density } \\
\text { (fissions/ce) }\end{array}$ & $\begin{array}{c}\text { U-235 } \\
\text { Burnup } \\
(\%)\end{array}$ \\
\hline 1 & 11 & 23744.85 & 392.03 & $8.91 \mathrm{E}+14$ & $2.40 \mathrm{E}+21$ & $17.33 \%$ \\
\hline 2 & 10.5 & 22422.25 & 370.19 & $8.98 \mathrm{E}+14$ & $2.26 \mathrm{E}+21$ & $16.38 \%$ \\
\hline 3 & 10 & 22738.26 & 375.41 & $9.12 \mathrm{E}+14$ & $2.30 \mathrm{E}+21$ & $16.64 \%$ \\
\hline 4 & 9.5 & 22879.16 & 377.74 & $9.27 \mathrm{E}+14$ & $2.33 \mathrm{E}+21$ & $16.89 \%$ \\
\hline 5 & 9 & 23138.93 & 382.02 & $9.37 \mathrm{E}+14$ & $2.34 \mathrm{E}+21$ & $16.95 \%$ \\
\hline 6 & 8.5 & 23634.97 & 390.21 & $9.55 \mathrm{E}+14$ & $2.38 \mathrm{E}+21$ & $17.27 \%$ \\
\hline 7 & 8 & 23647.91 & 390.43 & $9.73 \mathrm{E}+14$ & $2.40 \mathrm{E}+21$ & $17.39 \%$ \\
\hline 8 & 7.5 & 23609.92 & 389.80 & $9.75 \mathrm{E}+14$ & $2.45 \mathrm{E}+21$ & $17.71 \%$ \\
\hline 9 & 7 & 23964.65 & 395.66 & $9.74 \mathrm{E}+14$ & $2.48 \mathrm{E}+21$ & $17.96 \%$ \\
\hline 10 & 6.5 & 24107.11 & 398.01 & $9.84 \mathrm{E}+14$ & $2.48 \mathrm{E}+21$ & $17.90 \%$ \\
\hline 11 & 6 & 24177.32 & 399.17 & $9.94 \mathrm{E}+14$ & $2.50 \mathrm{E}+21$ & $18.08 \%$ \\
\hline 13 & 5.5 & 24455.46 & 403.76 & $9.96 \mathrm{E}+14$ & $2.52 \mathrm{E}+21$ & $18.15 \%$ \\
\hline 14 & 5 & 24354.30 & 402.09 & $1.00 \mathrm{E}+15$ & $2.54 \mathrm{E}+21$ & $18.34 \%$ \\
\hline 15 & 4.5 & 24539.57 & 405.15 & $1.00 \mathrm{E}+15$ & $2.54 \mathrm{E}+21$ & $18.27 \%$ \\
\hline 16 & 4 & 24661.65 & 407.16 & $1.01 \mathrm{E}+15$ & $2.56 \mathrm{E}+21$ & $18.46 \%$ \\
\hline 17 & 3.5 & 24802.30 & 409.49 & $1.02 \mathrm{E}+15$ & $2.59 \mathrm{E}+21$ & $18.65 \%$ \\
\hline 18 & 3 & 24996.93 & 412.70 & $1.01 \mathrm{E}+15$ & $2.59 \mathrm{E}+21$ & $18.65 \%$ \\
\hline 19 & 2.5 & 25019.45 & 413.07 & $1.02 \mathrm{E}+15$ & $2.59 \mathrm{E}+21$ & $18.65 \%$ \\
\hline 20 & 2 & 25345.22 & 418.45 & $1.04 \mathrm{E}+15$ & $2.63 \mathrm{E}+21$ & $18.90 \%$ \\
\hline 21 & 1.5 & 25169.13 & 415.54 & $1.03 \mathrm{E}+15$ & $2.63 \mathrm{E}+21$ & $18.97 \%$ \\
\hline 22 & 1 & 24969.87 & 412.25 & $1.02 \mathrm{E}+15$ & $2.62 \mathrm{E}+21$ & $18.84 \%$ \\
\hline 23 & 0.5 & 25401.95 & 419.39 & $1.03 \mathrm{E}+15$ & $2.62 \mathrm{E}+21$ & $18.84 \%$ \\
\hline 24 & 0 & 25300.50 & 417.71 & $1.03 \mathrm{E}+15$ & $2.65 \mathrm{E}+21$ & $19.03 \%$ \\
\hline 25 & -0.5 & 25206.34 & 416.16 & $1.04 \mathrm{E}+15$ & $2.62 \mathrm{E}+21$ & $18.90 \%$ \\
\hline 26 & -1 & 24924.95 & 411.51 & $1.02 \mathrm{E}+15$ & $2.61 \mathrm{E}+21$ & $18.78 \%$ \\
\hline 27 & -1.5 & 25108.41 & 414.54 & $1.03 \mathrm{E}+15$ & $2.62 \mathrm{E}+21$ & $18.84 \%$ \\
\hline 28 & -2 & 25291.40 & 417.56 & $1.03 \mathrm{E}+15$ & $2.66 \mathrm{E}+21$ & $19.16 \%$ \\
\hline 29 & -2.5 & 25171.07 & 415.57 & $1.02 \mathrm{E}+15$ & $2.63 \mathrm{E}+21$ & $18.90 \%$ \\
\hline 30 & -3 & 24896.27 & 411.04 & $1.02 \mathrm{E}+15$ & $2.63 \mathrm{E}+21$ & $18.97 \%$ \\
\hline 31 & -3.5 & 24690.80 & 407.65 & $1.02 \mathrm{E}+15$ & $2.64 \mathrm{E}+21$ & $18.97 \%$ \\
\hline 32 & -4 & 24691.61 & 407.66 & $1.01 \mathrm{E}+15$ & $2.65 \mathrm{E}+21$ & $19.03 \%$ \\
\hline 33 & -4.5 & 24730.68 & 408.30 & $1.02 \mathrm{E}+15$ & $2.60 \mathrm{E}+21$ & $18.71 \%$ \\
\hline 34 & -5 & 24790.46 & 409.29 & $1.01 \mathrm{E}+15$ & $2.58 \mathrm{E}+21$ & $18.59 \%$ \\
\hline 35 & -5.5 & 24496.48 & 404.44 & $1.01 \mathrm{E}+15$ & $2.58 \mathrm{E}+21$ & $18.59 \%$ \\
\hline 36 & -6 & 24550.03 & 405.32 & $1.00 \mathrm{E}+15$ & $2.56 \mathrm{E}+21$ & $18.46 \%$ \\
\hline 37 & -6.5 & 24661.82 & 407.17 & $1.01 \mathrm{E}+15$ & $2.58 \mathrm{E}+21$ & $18.59 \%$ \\
\hline 38 & -7 & 24546.04 & 405.26 & $9.96 \mathrm{E}+14$ & $2.55 \mathrm{E}+21$ & $18.40 \%$ \\
\hline 39 & -7.5 & 24044.25 & 396.97 & $9.93 \mathrm{E}+14$ & $2.51 \mathrm{E}+21$ & $18.15 \%$ \\
\hline 40 & -8 & 24181.86 & 399.24 & $9.82 \mathrm{E}+14$ & $2.50 \mathrm{E}+21$ & $18.08 \%$ \\
\hline 41 & -8.5 & 23971.85 & 395.78 & $9.76 \mathrm{E}+14$ & $2.49 \mathrm{E}+21$ & $17.96 \%$ \\
\hline 42 & -9 & 23853.55 & 393.82 & $9.75 \mathrm{E}+14$ & $2.50 \mathrm{E}+21$ & $18.02 \%$ \\
\hline 43 & -9.5 & 23973.06 & 395.80 & $9.67 \mathrm{E}+14$ & $2.42 \mathrm{E}+21$ & $17.52 \%$ \\
\hline 44 & -10 & 23981.65 & 395.94 & $9.60 \mathrm{E}+14$ & $2.42 \mathrm{E}+21$ & $17.45 \%$ \\
\hline 45 & -10.5 & 23516.21 & 388.25 & $9.37 \mathrm{E}+14$ & $2.41 \mathrm{E}+21$ & $17.45 \%$ \\
\hline
\end{tabular}


Table 11: Cycle 151A, MCNP-Calculated HGRs, Neutron Flux, Depletion and Fission Density for AFIP-6 MKII, Plate 6II-1, 56.1 EFPD (EOC) Center Lobe Power at 23.9 MW. ${ }^{2}$

\begin{tabular}{|c|c|c|c|c|c|c|}
\hline Node & $\begin{array}{l}\text { Distance from } \\
\text { Centerline } \\
\text { (in.) }\end{array}$ & $\begin{array}{c}\text { Fission Power } \\
\text { Density } \\
\text { (W/cc) }\end{array}$ & $\begin{array}{c}\text { Surface } \\
\text { Heat Flux } \\
\left(W / \mathrm{cm}^{2}\right)\end{array}$ & $\begin{array}{c}\text { Neutron } \\
\text { Flux } \\
\left(\mathbf{n} / \mathrm{cm}^{2} \mathrm{sec}\right)\end{array}$ & $\begin{array}{c}\text { Fission } \\
\text { Density } \\
\text { (fissions/ce) }\end{array}$ & $\begin{array}{c}\text { U-235 } \\
\text { Burnup } \\
(\%)\end{array}$ \\
\hline 1 & 11 & 21120.13 & 348.69 & $8.71 \mathrm{E}+14$ & $3.95 \mathrm{E}+21$ & $28.10 \%$ \\
\hline 2 & 10.5 & 20089.19 & 331.67 & $8.80 \mathrm{E}+14$ & $3.73 \mathrm{E}+21$ & $26.65 \%$ \\
\hline 3 & 10 & 20257.74 & 334.46 & $8.92 \mathrm{E}+14$ & $3.79 \mathrm{E}+21$ & $27.03 \%$ \\
\hline 4 & 9.5 & 20417.17 & 337.09 & $9.05 \mathrm{E}+14$ & $3.83 \mathrm{E}+21$ & $27.35 \%$ \\
\hline 5 & 9 & 20575.07 & 339.69 & $9.14 \mathrm{E}+14$ & $3.86 \mathrm{E}+21$ & $27.54 \%$ \\
\hline 6 & 8.5 & 20886.12 & 344.83 & $9.31 \mathrm{E}+14$ & $3.93 \mathrm{E}+21$ & $28.04 \%$ \\
\hline 7 & 8 & 20971.77 & 346.24 & $9.49 \mathrm{E}+14$ & $3.95 \mathrm{E}+21$ & $28.17 \%$ \\
\hline 8 & 7.5 & 21002.81 & 346.76 & $9.51 \mathrm{E}+14$ & $3.99 \mathrm{E}+21$ & $28.48 \%$ \\
\hline 9 & 7 & 21275.14 & 351.25 & $9.50 \mathrm{E}+14$ & $4.05 \mathrm{E}+21$ & $28.86 \%$ \\
\hline 10 & 6.5 & 21352.66 & 352.53 & $9.57 \mathrm{E}+14$ & $4.06 \mathrm{E}+21$ & $28.86 \%$ \\
\hline 11 & 6 & 21351.21 & 352.51 & $9.67 \mathrm{E}+14$ & $4.09 \mathrm{E}+21$ & $29.11 \%$ \\
\hline 13 & 5.5 & 21563.51 & 356.01 & $9.67 \mathrm{E}+14$ & $4.12 \mathrm{E}+21$ & $29.24 \%$ \\
\hline 14 & 5 & 21526.58 & 355.40 & $9.79 \mathrm{E}+14$ & $4.14 \mathrm{E}+21$ & $29.36 \%$ \\
\hline 15 & 4.5 & 21659.45 & 357.60 & $9.75 \mathrm{E}+14$ & $4.14 \mathrm{E}+21$ & $29.43 \%$ \\
\hline 16 & 4 & 21748.67 & 359.07 & $9.88 \mathrm{E}+14$ & $4.18 \mathrm{E}+21$ & $29.62 \%$ \\
\hline 17 & 3.5 & 21903.17 & 361.62 & $9.92 \mathrm{E}+14$ & $4.21 \mathrm{E}+21$ & $29.87 \%$ \\
\hline 18 & 3 & 21958.46 & 362.53 & $9.85 \mathrm{E}+14$ & $4.23 \mathrm{E}+21$ & $29.99 \%$ \\
\hline 19 & 2.5 & 22011.74 & 363.41 & $9.92 \mathrm{E}+14$ & $4.23 \mathrm{E}+21$ & $29.99 \%$ \\
\hline 20 & 2 & 22247.28 & 367.30 & $1.01 \mathrm{E}+15$ & $4.29 \mathrm{E}+21$ & $30.37 \%$ \\
\hline 21 & 1.5 & 22136.46 & 365.47 & $1.00 \mathrm{E}+15$ & $4.28 \mathrm{E}+21$ & $30.31 \%$ \\
\hline 22 & 1 & 22015.27 & 363.47 & $9.91 \mathrm{E}+14$ & $4.26 \mathrm{E}+21$ & $30.18 \%$ \\
\hline 23 & 0.5 & 22299.65 & 368.17 & $1.00 \mathrm{E}+15$ & $4.28 \mathrm{E}+21$ & $30.31 \%$ \\
\hline 24 & 0 & 22171.71 & 366.05 & $1.00 \mathrm{E}+15$ & $4.30 \mathrm{E}+21$ & $30.43 \%$ \\
\hline 25 & -0.5 & 22111.24 & 365.06 & $1.01 \mathrm{E}+15$ & $4.27 \mathrm{E}+21$ & $30.31 \%$ \\
\hline 26 & -1 & 21942.29 & 362.27 & $9.95 \mathrm{E}+14$ & $4.24 \mathrm{E}+21$ & $30.12 \%$ \\
\hline 27 & -1.5 & 22018.03 & 363.52 & $1.00 \mathrm{E}+15$ & $4.26 \mathrm{E}+21$ & $30.25 \%$ \\
\hline 28 & -2 & 22218.18 & 366.82 & $1.00 \mathrm{E}+15$ & $4.31 \mathrm{E}+21$ & $30.56 \%$ \\
\hline 29 & -2.5 & 22105.81 & 364.97 & $9.92 \mathrm{E}+14$ & $4.28 \mathrm{E}+21$ & $30.31 \%$ \\
\hline 30 & -3 & 21982.25 & 362.93 & $9.96 \mathrm{E}+14$ & $4.26 \mathrm{E}+21$ & $30.18 \%$ \\
\hline 31 & -3.5 & 21898.18 & 361.54 & $9.97 \mathrm{E}+14$ & $4.25 \mathrm{E}+21$ & $30.12 \%$ \\
\hline 32 & -4 & 21790.72 & 359.76 & $9.89 \mathrm{E}+14$ & $4.26 \mathrm{E}+21$ & $30.18 \%$ \\
\hline 33 & -4.5 & 21824.28 & 360.32 & $9.91 \mathrm{E}+14$ & $4.22 \mathrm{E}+21$ & $29.93 \%$ \\
\hline 34 & -5 & 21837.40 & 360.54 & $9.86 \mathrm{E}+14$ & $4.20 \mathrm{E}+21$ & $29.80 \%$ \\
\hline 35 & -5.5 & 21656.22 & 357.54 & $9.82 \mathrm{E}+14$ & $4.18 \mathrm{E}+21$ & $29.62 \%$ \\
\hline 36 & -6 & 21690.03 & 358.10 & $9.76 \mathrm{E}+14$ & $4.17 \mathrm{E}+21$ & $29.62 \%$ \\
\hline 37 & -6.5 & 21833.76 & 360.48 & $9.82 \mathrm{E}+14$ & $4.19 \mathrm{E}+21$ & $29.80 \%$ \\
\hline 38 & -7 & 21672.74 & 357.82 & $9.69 \mathrm{E}+14$ & $4.15 \mathrm{E}+21$ & $29.49 \%$ \\
\hline 39 & -7.5 & 21282.65 & 351.38 & $9.64 \mathrm{E}+14$ & $4.09 \mathrm{E}+21$ & $29.05 \%$ \\
\hline 40 & -8 & 21361.39 & 352.68 & $9.57 \mathrm{E}+14$ & $4.09 \mathrm{E}+21$ & $29.05 \%$ \\
\hline 41 & -8.5 & 21194.91 & 349.93 & $9.54 \mathrm{E}+14$ & $4.05 \mathrm{E}+21$ & $28.86 \%$ \\
\hline 42 & -9 & 21179.77 & 349.68 & $9.50 \mathrm{E}+14$ & $4.06 \mathrm{E}+21$ & $28.86 \%$ \\
\hline 43 & -9.5 & 21196.90 & 349.96 & $9.42 \mathrm{E}+14$ & $3.99 \mathrm{E}+21$ & $28.42 \%$ \\
\hline 44 & -10 & 21231.97 & 350.54 & $9.34 \mathrm{E}+14$ & $3.99 \mathrm{E}+21$ & $28.42 \%$ \\
\hline 45 & -10.5 & 20864.69 & 344.48 & $9.14 \mathrm{E}+14$ & $3.95 \mathrm{E}+21$ & $28.10 \%$ \\
\hline
\end{tabular}




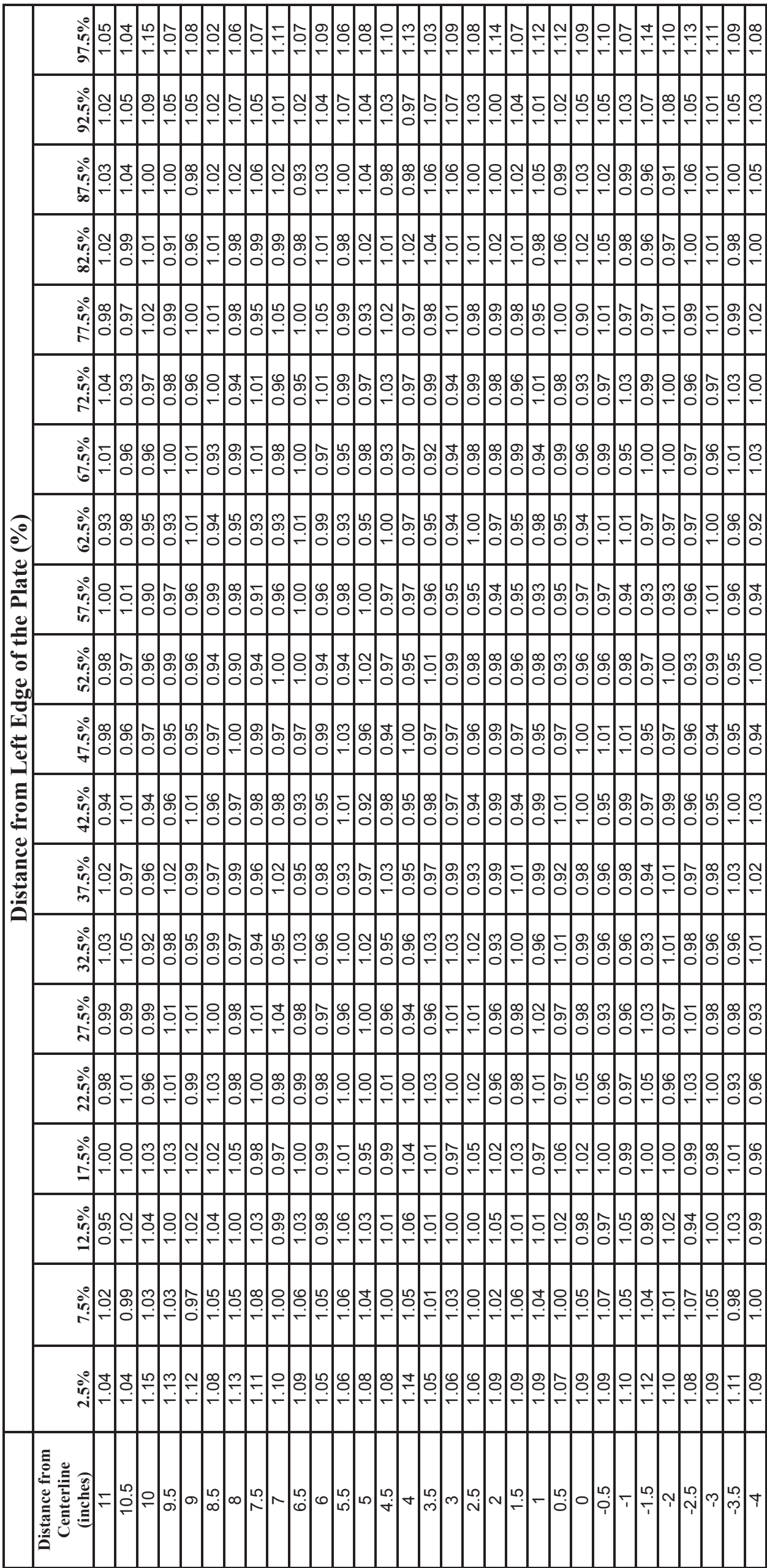




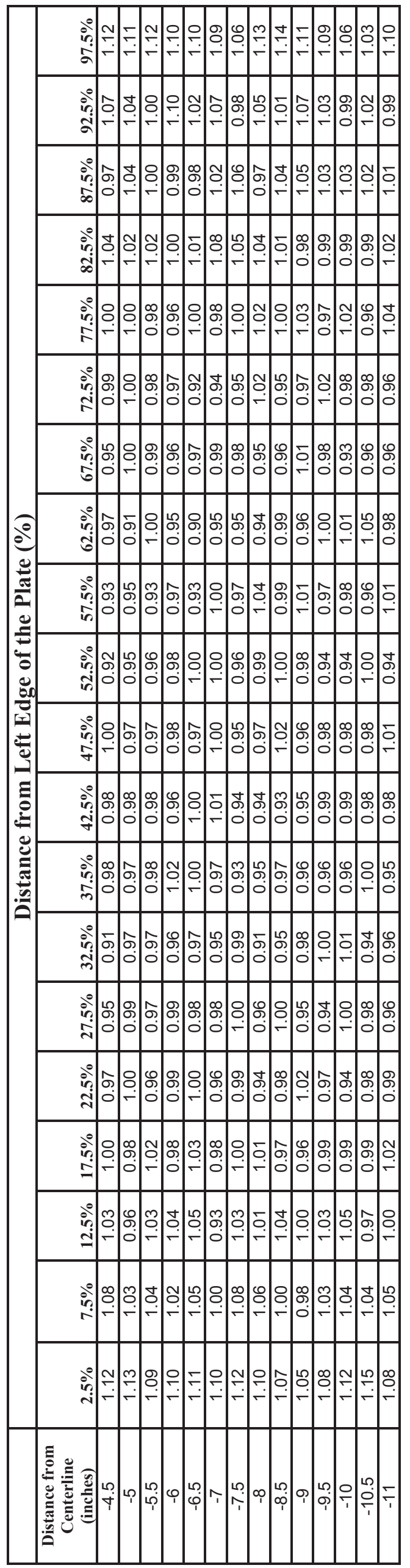




\section{HYDRAULIC TESTING}

Flow tests were performed to characterize the test assembly designed to irradiate full-size plates for the RERTR program in the ATR. The holder assembly design was used for several plate tests that were conducted in the CFT position ${ }^{5}$.

The test apparatus was designed and constructed to simulate the ATR CFT position geometry. The holder was fabricated such that the orifice plate on the bottom of the test train could be screwed on (rather than welded) to allow variation of the orifice diameter. The results of the flow tests were used to generate estimates of the coolant velocity and flow rate and are reported in Table $13^{5}$.

Table 13. AFIP irradiation vehicle flow conditions for each orifice configuration ${ }^{5}$.

\begin{tabular}{|c|c|c|c|c|}
\hline Configuration & $\begin{array}{c}\text { Total Internal } \\
\text { Loss } \\
\text { Coefficient }\end{array}$ & $\begin{array}{c}\text { Total Holder } \\
\text { Internal Flow } \\
(\mathrm{gpm})\end{array}$ & $\begin{array}{c}\text { Channel } \\
\text { Coolant Flow } \\
(\mathrm{gpm})\end{array}$ & $\begin{array}{c}\text { Channel } \\
\text { Coolant } \\
\text { Velocity }(\mathrm{m} / \mathrm{s})\end{array}$ \\
\hline $6 \mathrm{~mm}$ orifice & 0.1709 & 20.8 & 6.6 & 1.7 \\
\hline $7 \mathrm{~mm}$ orifice & 0.1203 & 24.8 & 7.9 & 2.0 \\
\hline $8 \mathrm{~mm}$ orifice & 0.0869 & 29.2 & 9.3 & 2.4 \\
\hline $8.1 \mathrm{~mm}$ orifice & 0.0861 & 29.3 & 9.3 & 2.4 \\
\hline $9 \mathrm{~mm}$ orifice & 0.0680 & 33.0 & 10.5 & 2.7 \\
\hline $10 \mathrm{~mm}$ orifice & 0.0568 & 36.1 & 11.5 & 3.0 \\
\hline Open (no orifice) & 0.00164 & 212.5 & 67.5 & 17.4 \\
\hline
\end{tabular}

Based on the results from the hydraulic testing, and the results from the original AFIP-6 experiment, the orifice was removed to allow a flow rate of $18.2 \mathrm{~m} / \mathrm{s}(59.6 \mathrm{ft} / \mathrm{s})$ through the coolant channels (see Figure 8 below $)^{6}$.
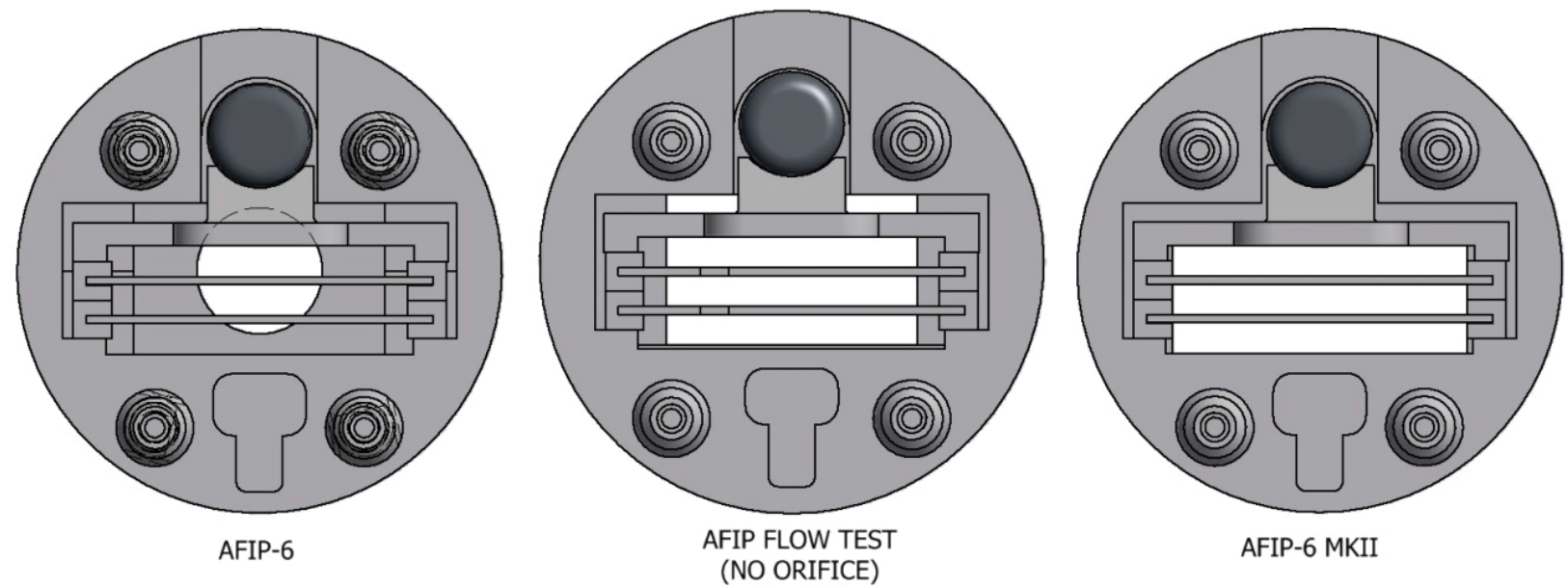

Figure 8. AFIP-6 Orifice Selection. 


\section{AS-RUN THERMAL ANALYSIS}

The thermal as-run analysis was performed using the as-built geometry, MCNP-calculated surface heat flux $\left(\mathrm{W} / \mathrm{cm}^{2}\right)$ and nominal coolant channel flow rate. ABAQUS ${ }^{7}$ was used to calculate the coolant channel temperatures and plate surface temperatures.

The heat transfer correlation used to calculate these temperatures was calculated from the Colburn equation (equation 5-50c from Reference 8):

$$
N u=\frac{h D}{k}=0.023 R e^{0.8} \operatorname{Pr}^{0.3}
$$

Where $\mathrm{Nu}$ is the Nusselt number, $\mathrm{h}$ is the heat transfer coefficient, $\mathrm{D}$ is the hydraulic diameter, $\mathrm{k}$ is the thermal conductivity, Re is the Reynolds number and Pr is the Prandlt number.

\subsection{Coolant Channel Temperature}

The coolant temperature was analyzed at the two flow channels surrounding the plate in position A in the test assembly. For each cycle interval, the coolant temperature was plotted as a function of location along the test assembly with 0.0 in. being at the top of the assembly. These plots are show in Figure 10 through Figure 13.

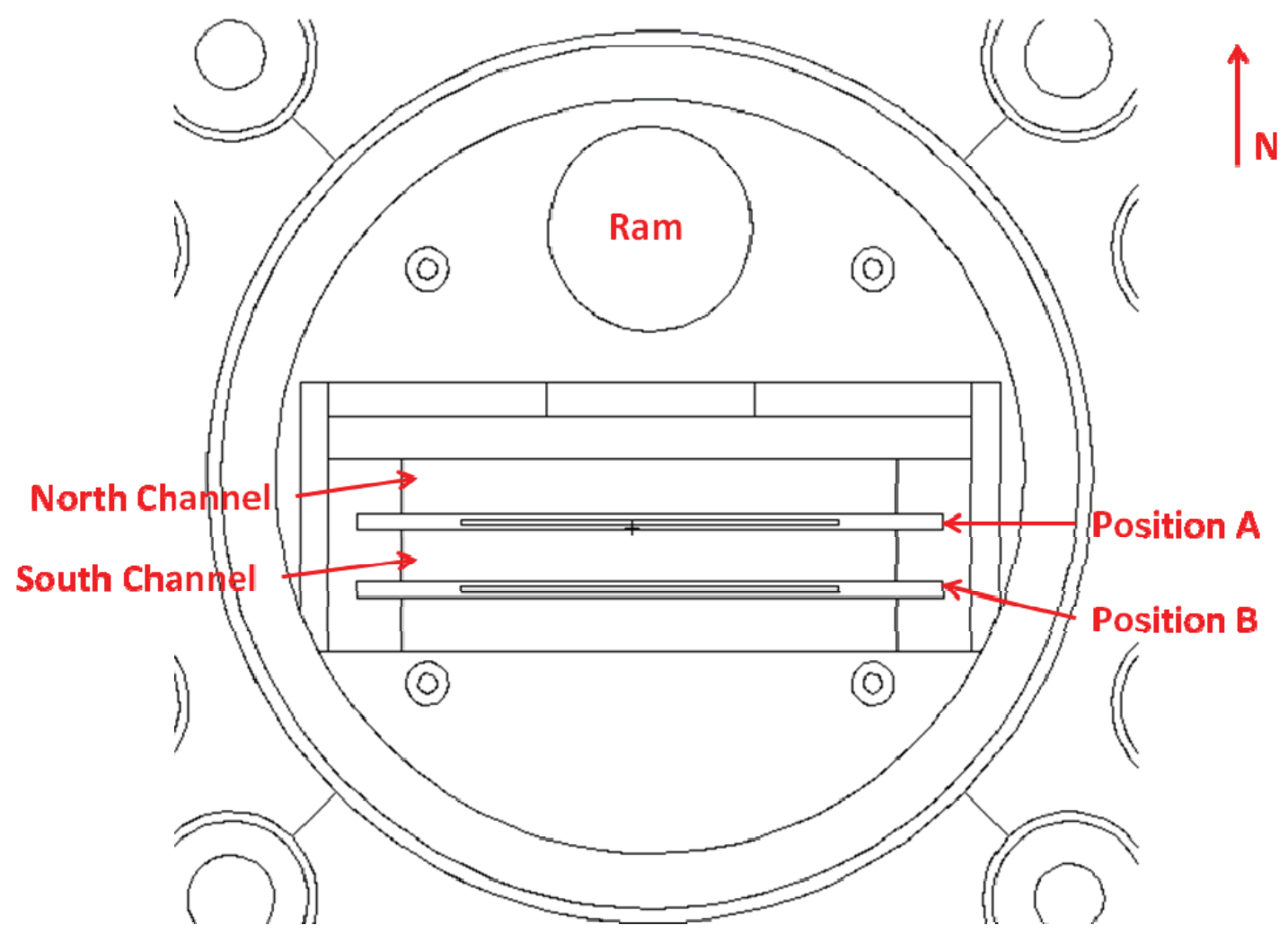

Figure 9. Coolant channel diagram. 


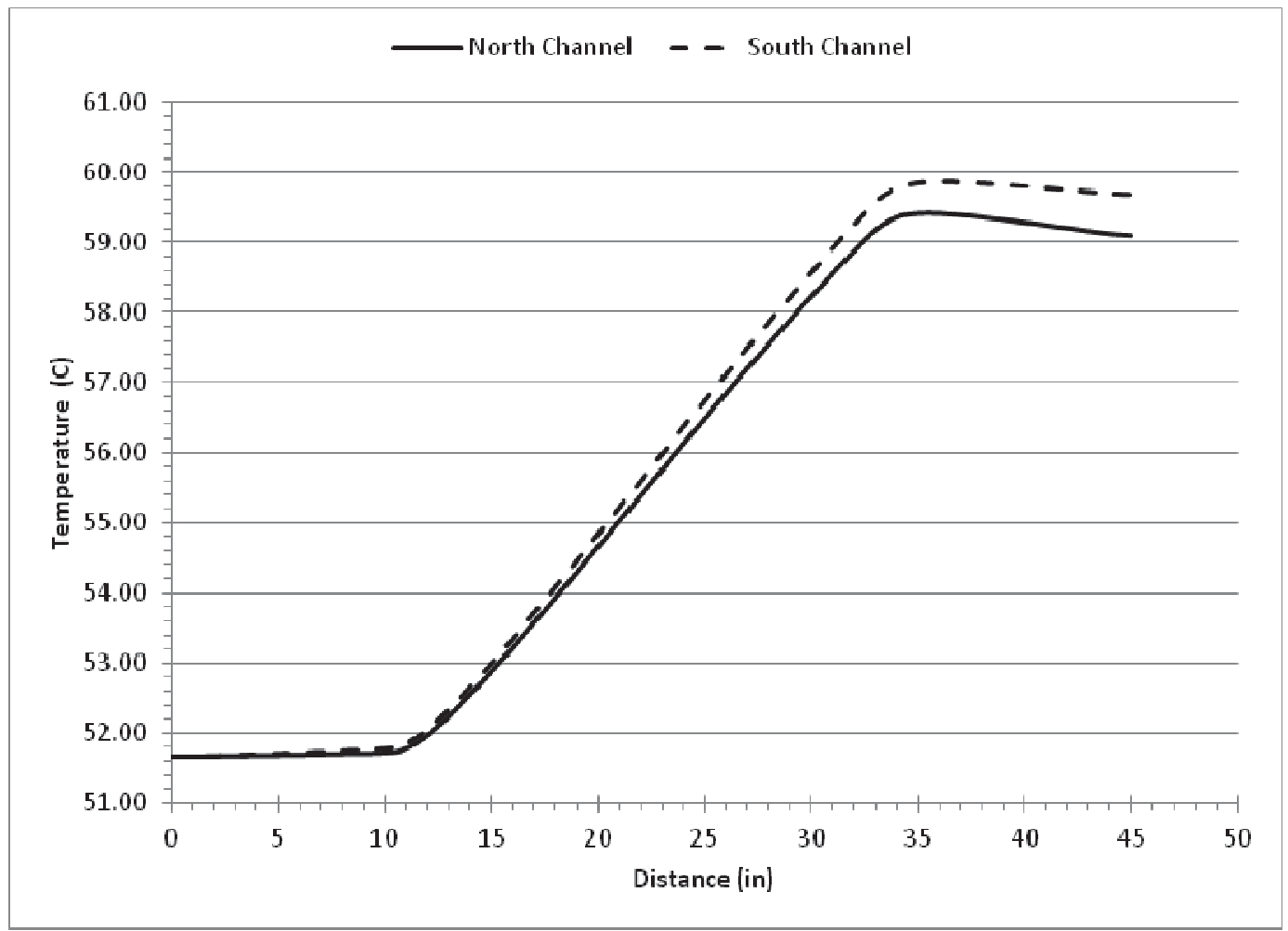

Figure 10: Coolant channel temperatures as a function of location along the AFIP-6 MKII test assembly at BOC 151A (0.0 EFPD).

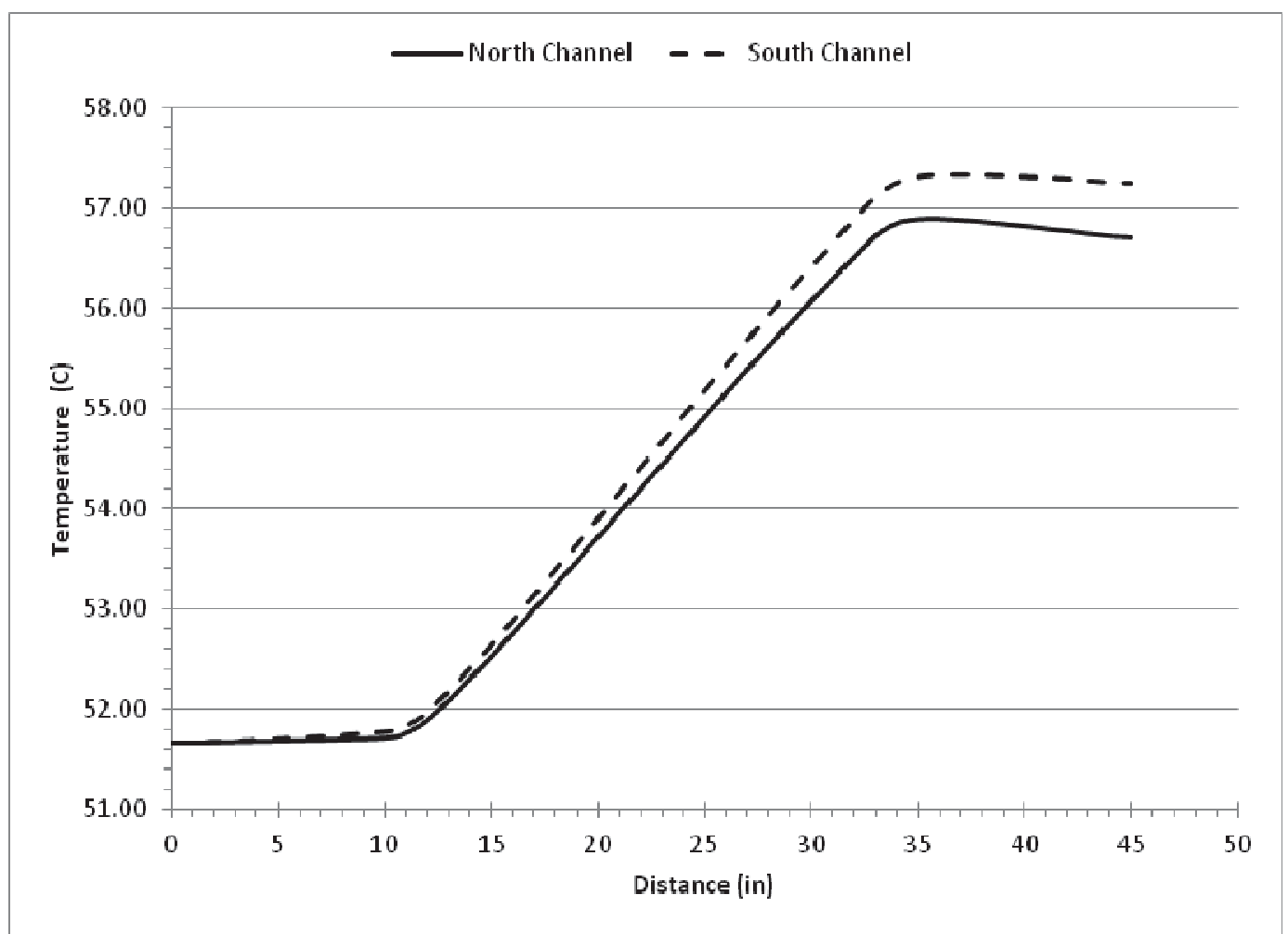

Figure 11: Coolant channel temperatures as a function of location along the AFIP-6 MKII test assembly at MOC1 151A (15.0 EFPD). 


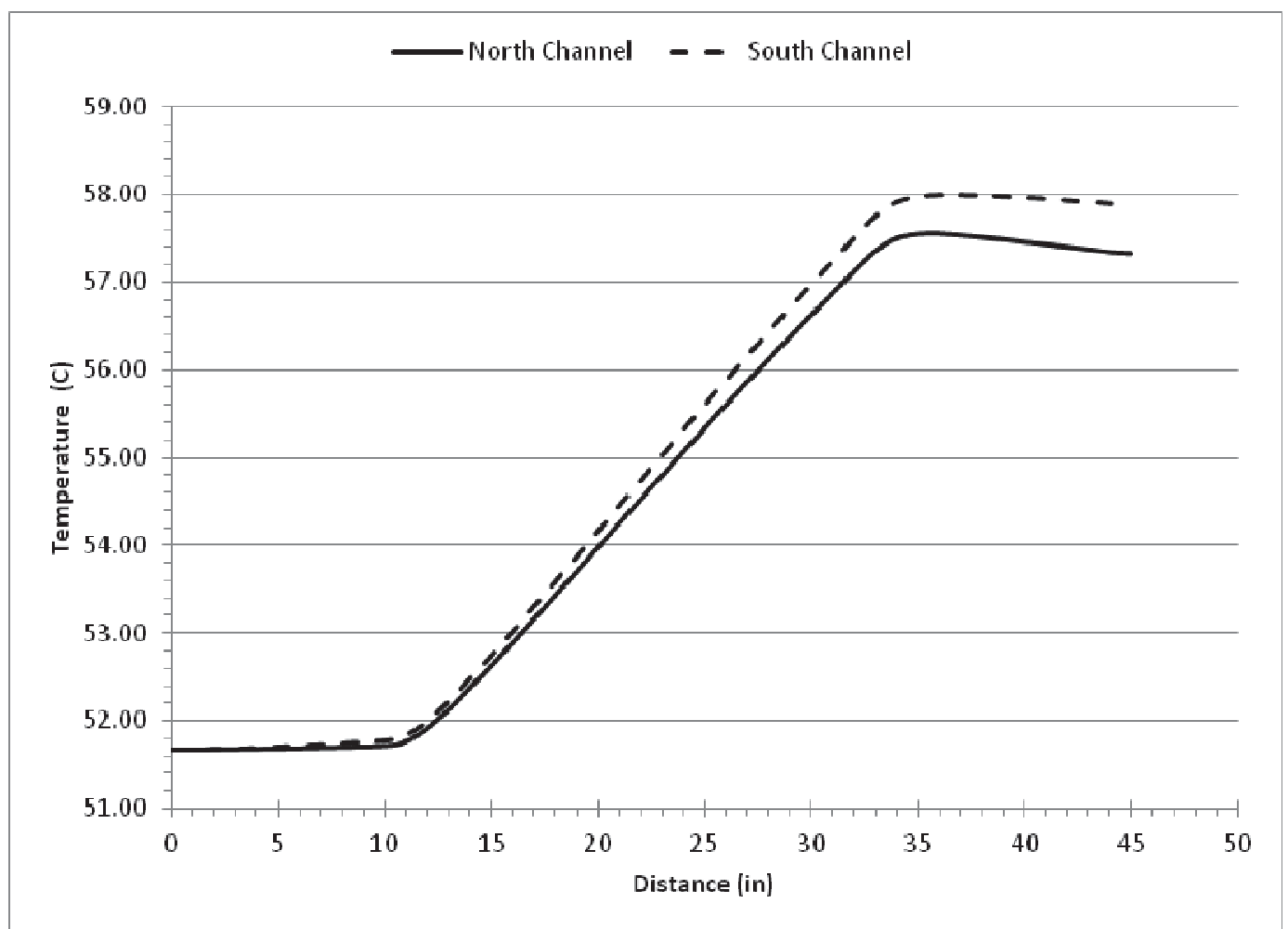

Figure 12: Coolant channel temperatures as a function of location along the AFIP-6 MKII test assembly at MOC2 151A (34.0 EFPD).

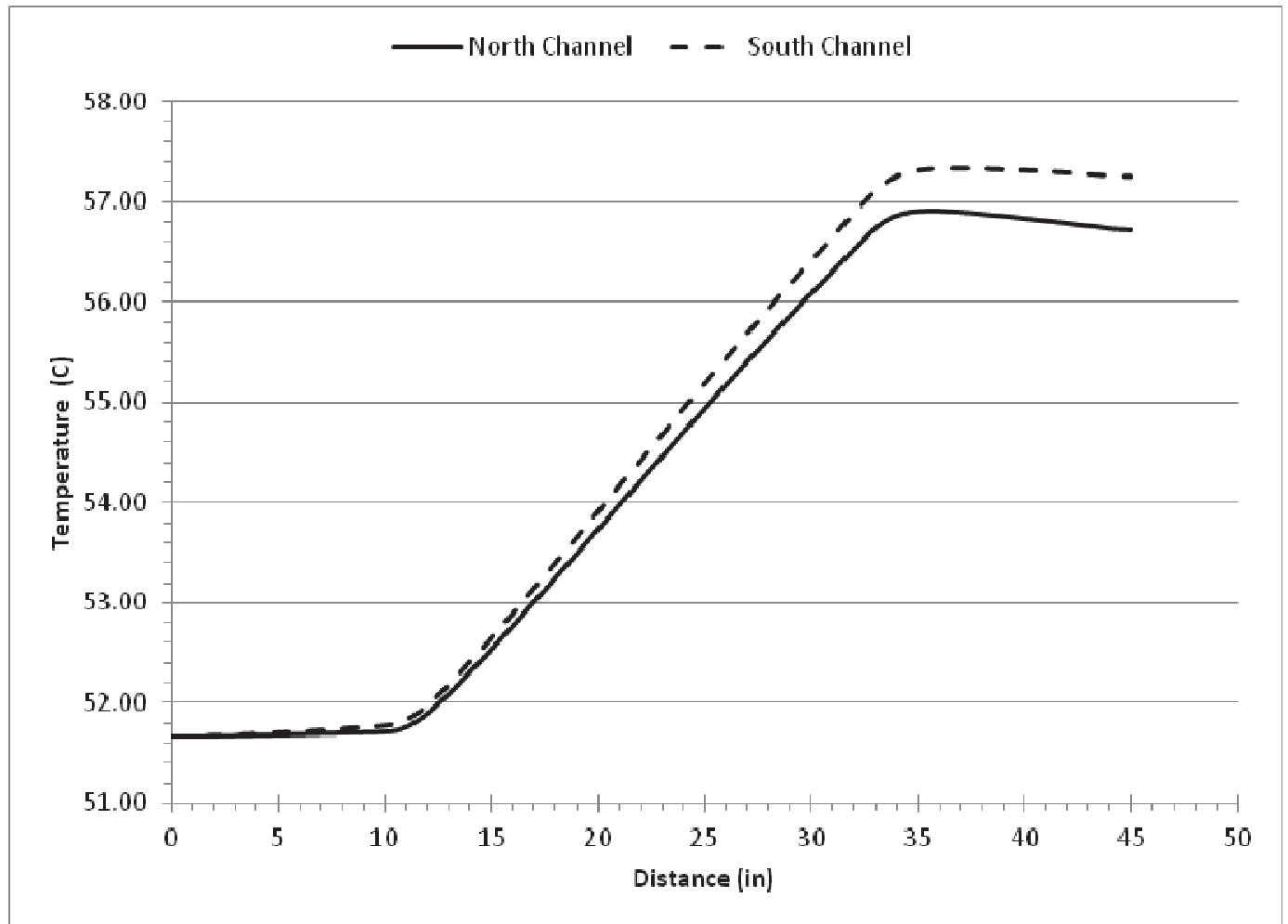

Figure 13: Coolant channel temperatures as a function of location along the AFIP-6 MKII test assembly at EOC 151A (56.1 EFPD). 
I n

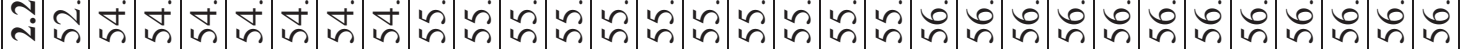

马. ก. m Э.

- ᄀ. J m 0.0 m n -

$\stackrel{\infty}{\mathscr{E}}$

त्ञ

$\frac{\pi}{\frac{\pi}{2}}$

(2)

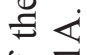

世纺

은

है ठे

$\stackrel{0}{0}$

을

동

3

记

를

호

Ч

응

का

गे

\&

क क

을

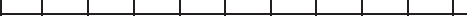

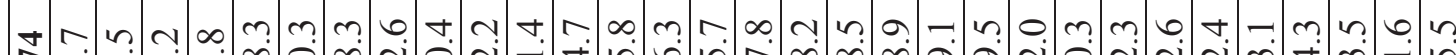

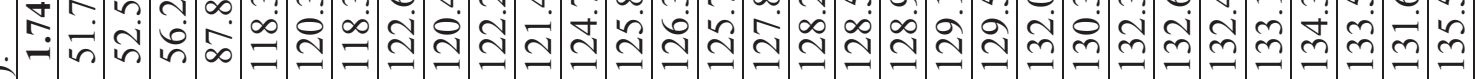
2

Ir r m mo r o a d n m

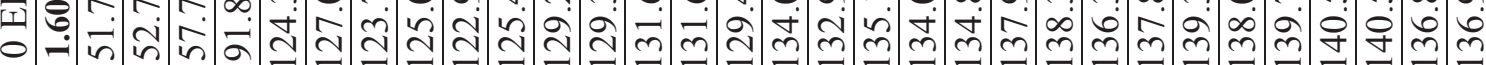
$\varangle$

¿ பூ 里

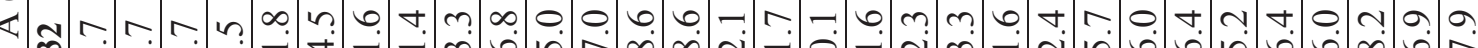

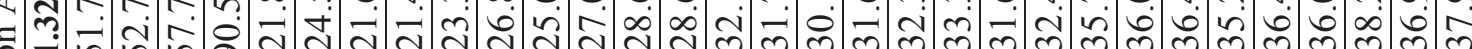

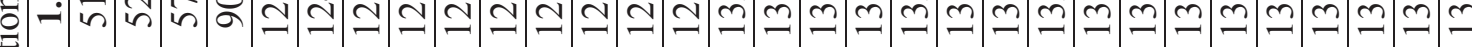

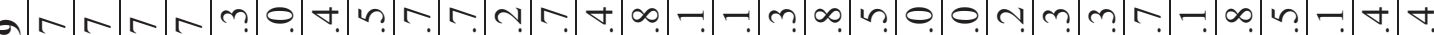

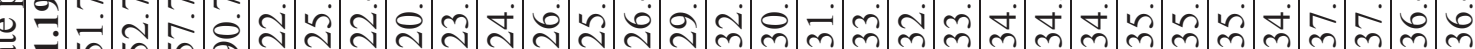
$\frac{\pi}{2}$

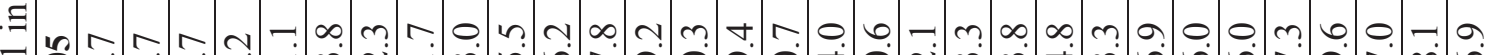
ت઼

$\stackrel{0}{\frac{\pi}{*}}$

完

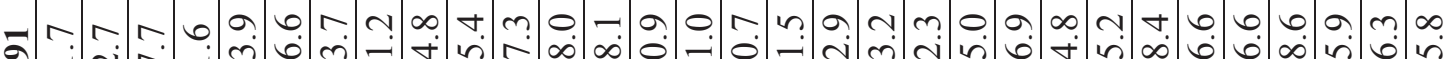

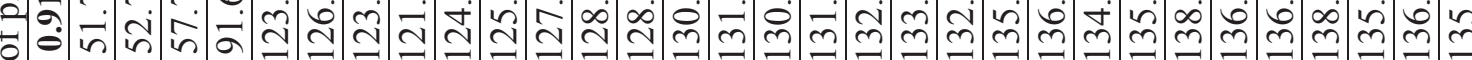
$\frac{0}{2}$

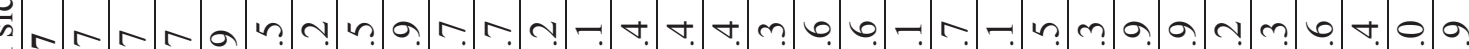
تُ Z

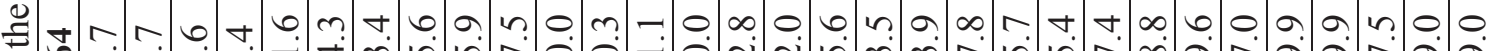

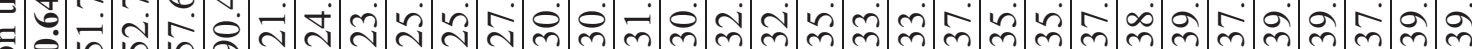
常

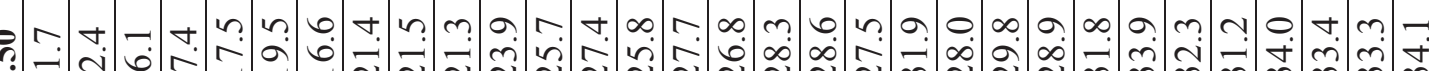

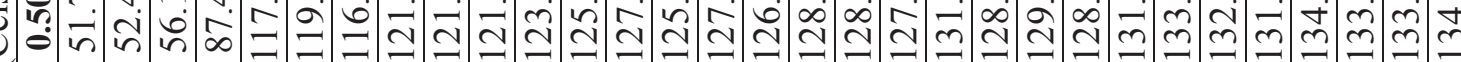

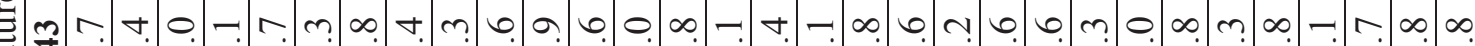
¿ே in in N

I

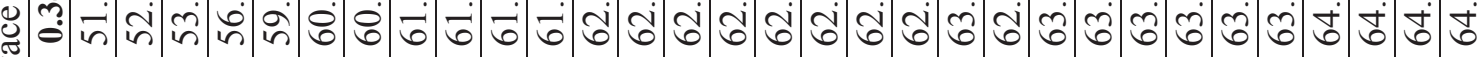

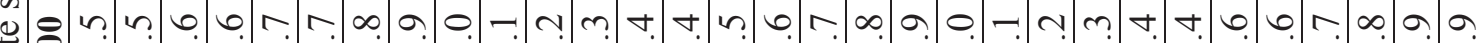
胥 


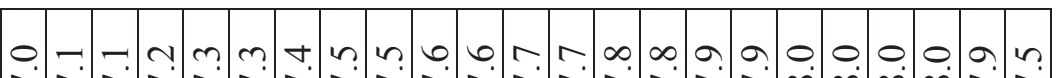

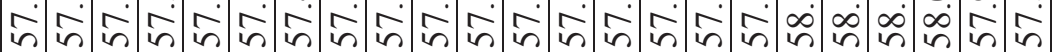

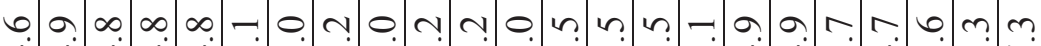

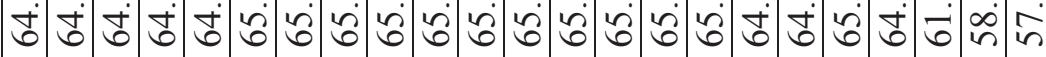

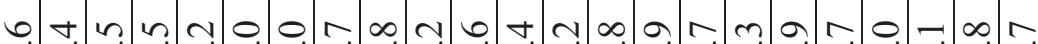
જ̆

ᄀ. c

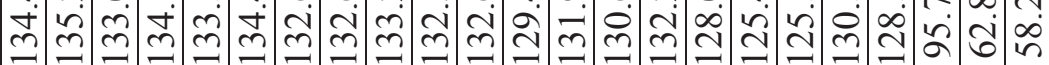

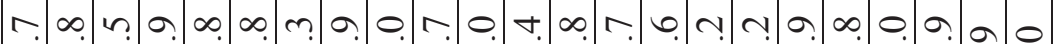

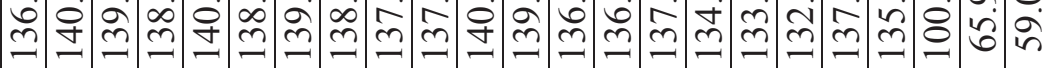

n n m 0 c n $n$ a mं nं $=-1=-1=-1=-1=-1=0$ in

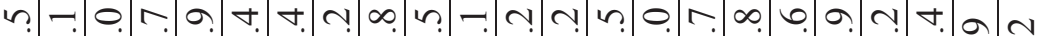

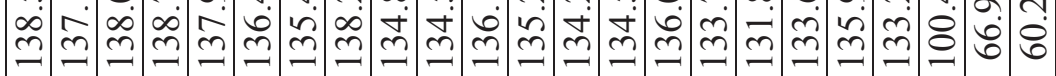

o a o a n a a r.

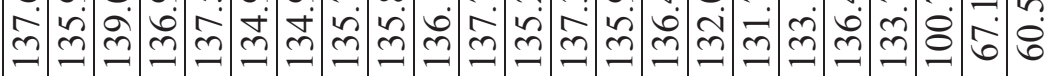

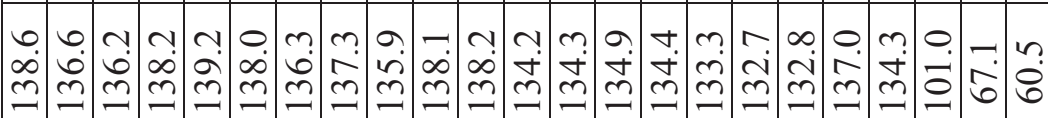

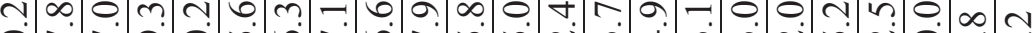

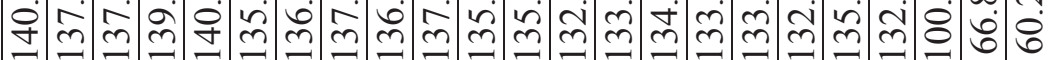

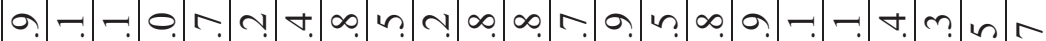

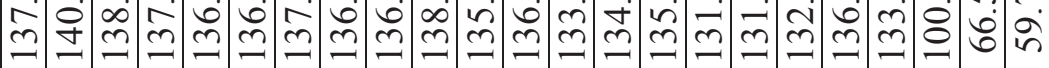
m r c n

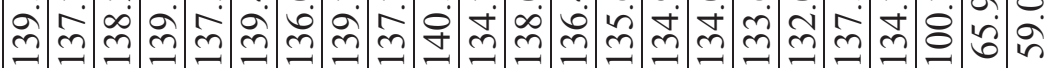

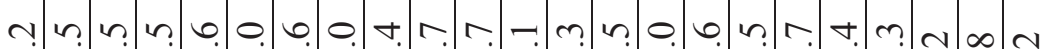

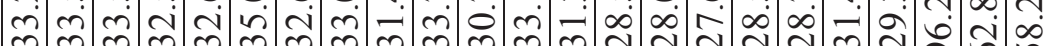

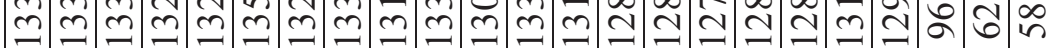

m a á

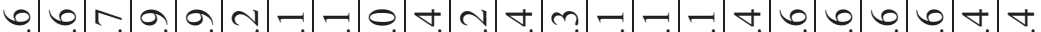

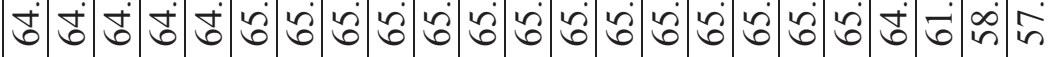

$0 .-\pi)$ m

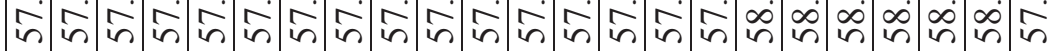
管 


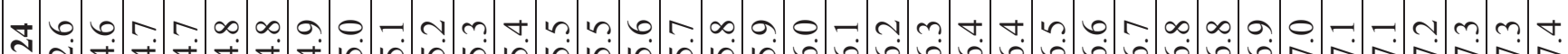
तี ถี่

g.

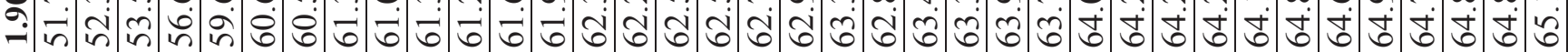

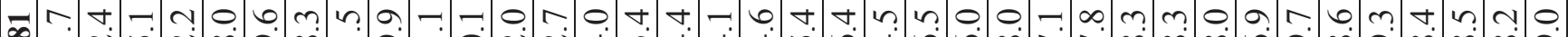

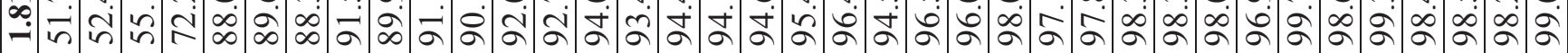

a n n (ิ)

¡ $\dot{\sim}$ ن

,

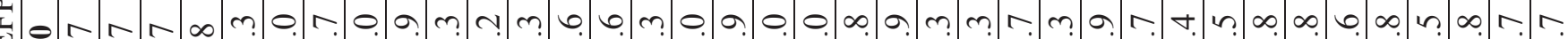

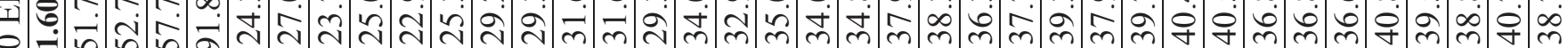

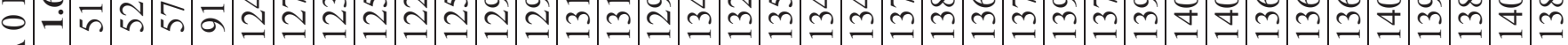

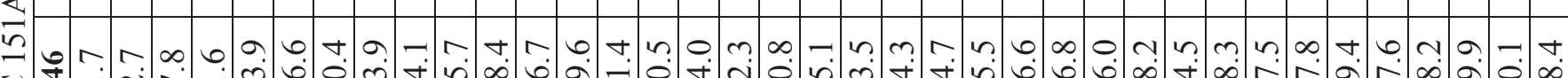
U.

פิ

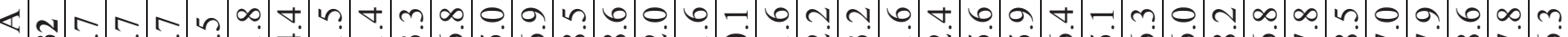
\#

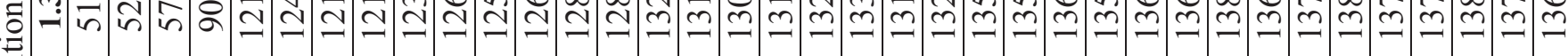

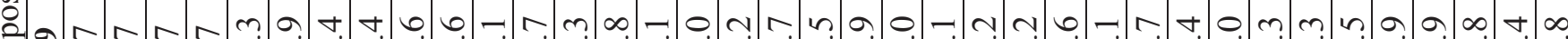

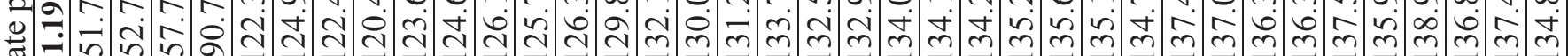

2

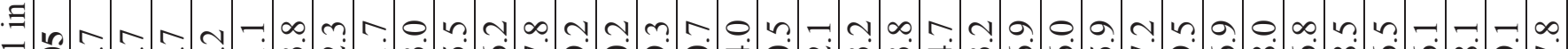

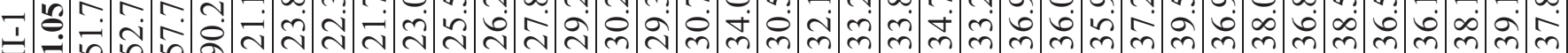

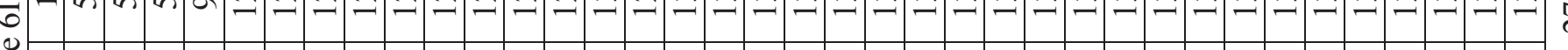

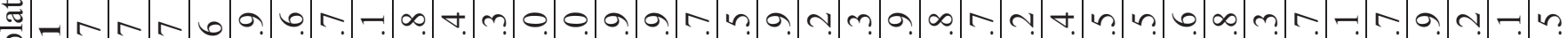

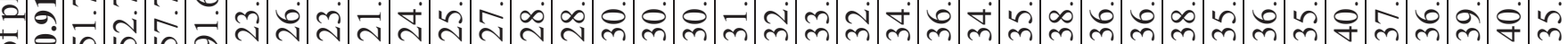

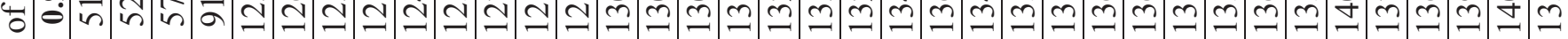

$\frac{0}{2}$

n N r r a n c n

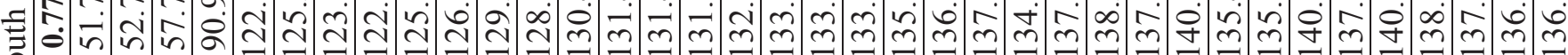
\&

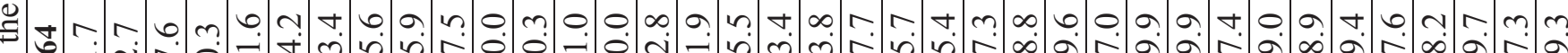
=

(2)

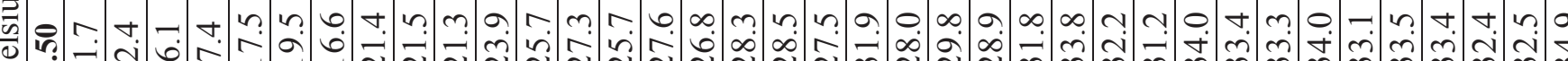
乌்

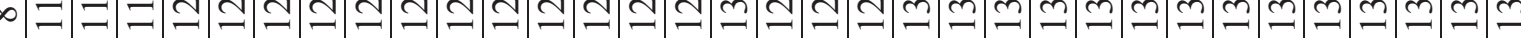

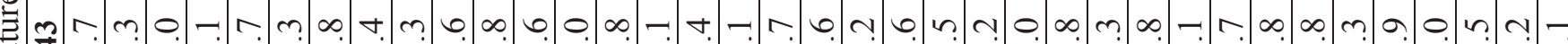

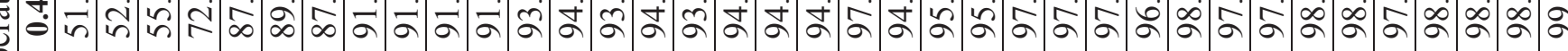

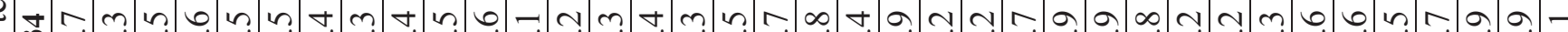

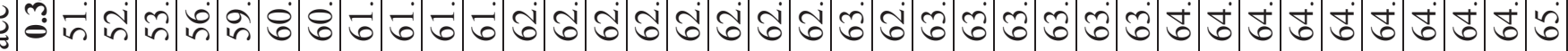

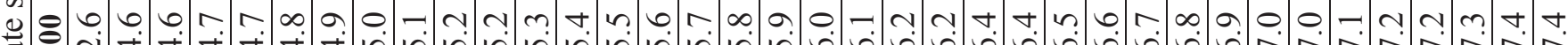
$\frac{\pi}{2} \dot{\theta}$ in ni

-

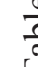




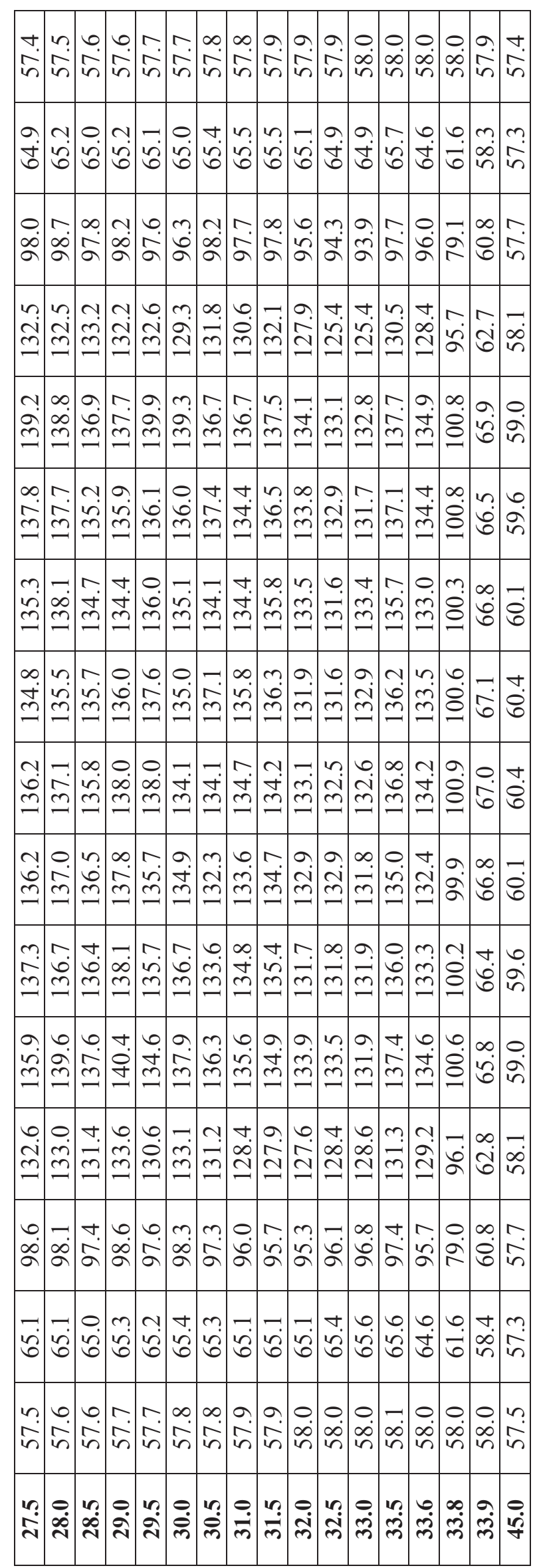




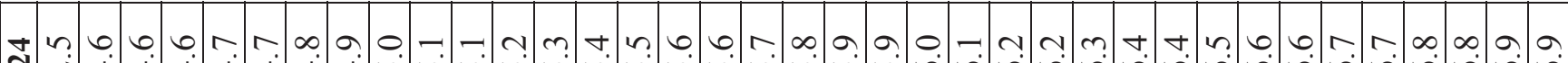

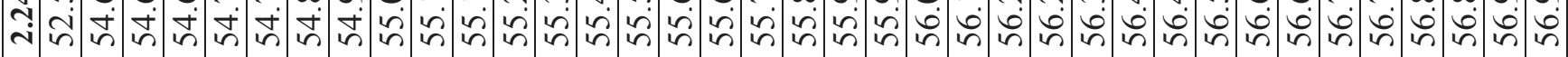

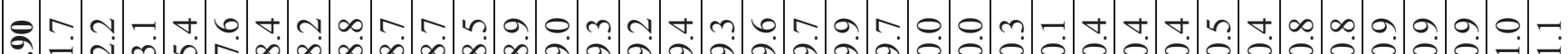

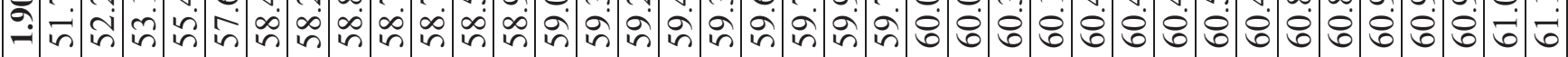

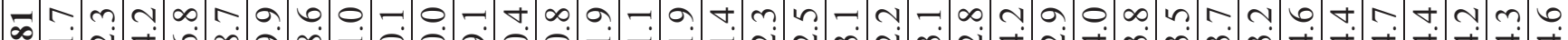

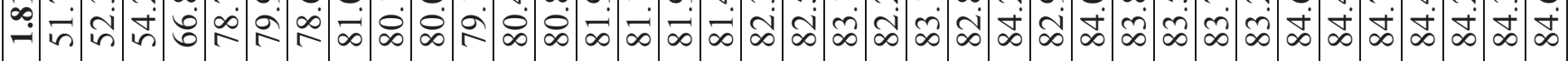

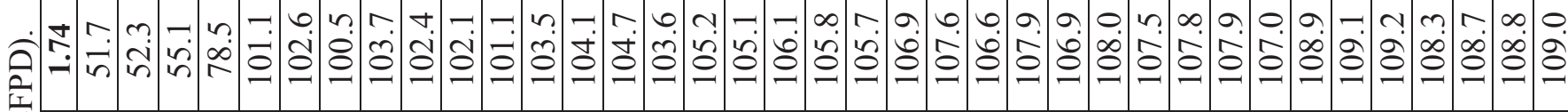

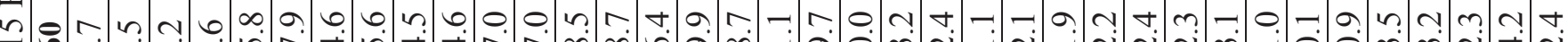
«

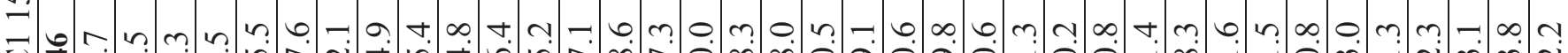
ப)

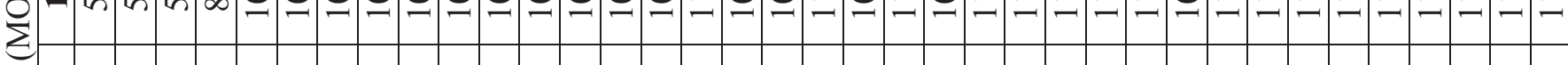

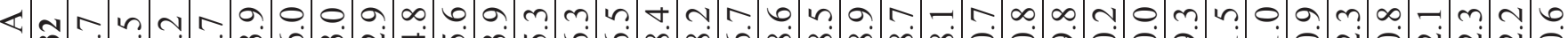
Бี (ำ

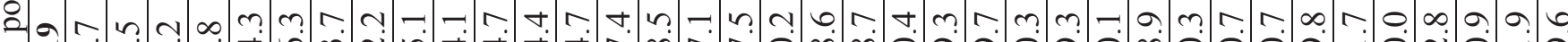

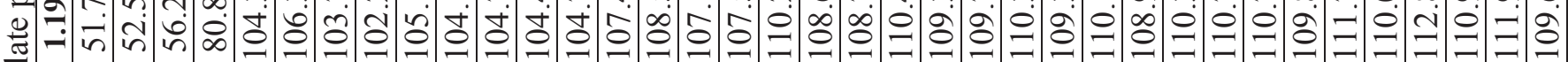

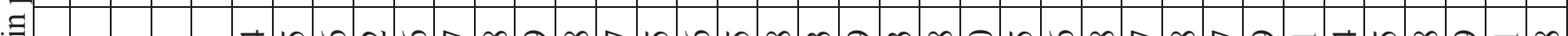

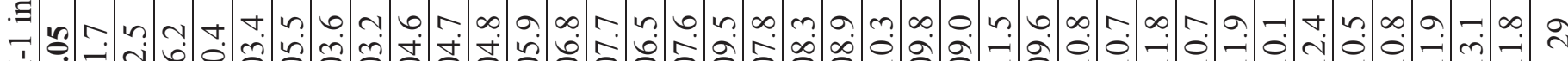
ت̇ 䒿 a r. $n$ n $n$ n

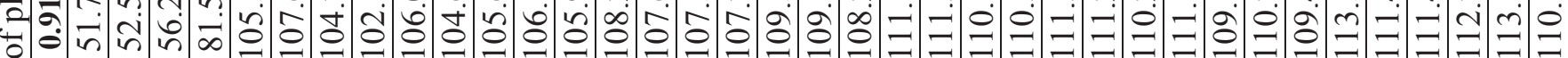
$\frac{\pi}{\pi}$

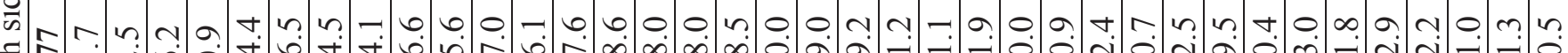

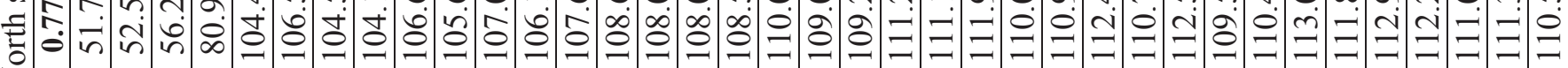
Z

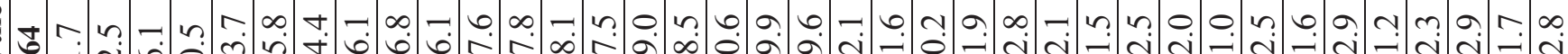
a $\dot{0}$ i ?ִ

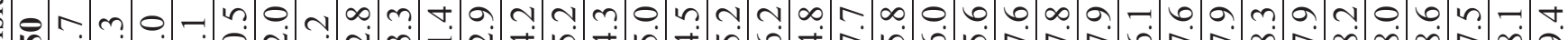
仓 ڤ్

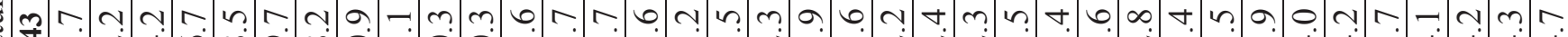
苟 in

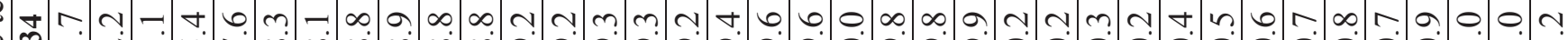

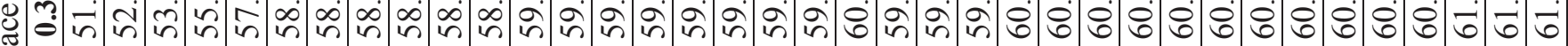
$\exists$

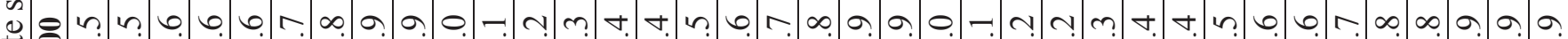
a

$\stackrel{\circ}{\circ}$

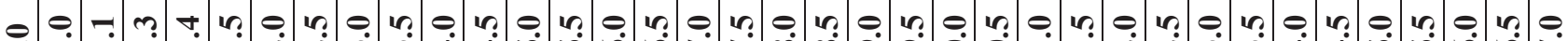

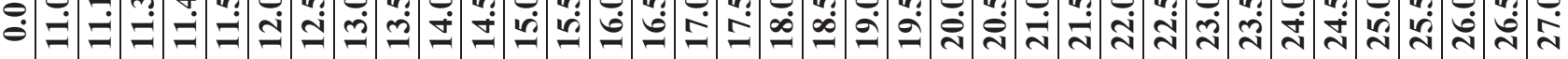




\begin{tabular}{|c|c|c|c|c|c|c|c|c|c|c|c|c|c|c|c|c|}
\hline 0. & o & $\begin{array}{l}0 \\
\text { in }\end{array}$ & $\frac{\pi}{n}$ & $\underset{n}{-}$ & $\frac{N}{n}$ & $\begin{array}{l}2 \\
\frac{1}{n} \\
\vdots\end{array}$ & 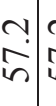 & 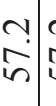 & c & $m$ & $\begin{array}{c}n \\
i n \\
n\end{array}$ & $\begin{array}{l}n \\
\tilde{n}\end{array}$ & $\begin{array}{c}n \\
\tilde{n}\end{array}$ & ?ִ. & ?ִ. & $\mid \begin{array}{l}n \\
6 \\
n \\
n\end{array}$ \\
\hline & $\frac{N}{6}$ & ד. & & $\frac{N}{\square}$ & 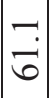 & $\frac{n}{6}$ & $\frac{n}{6}$ & $\begin{array}{l}0 \\
\dot{0}\end{array}$ & $\frac{\nabla}{6}$ & $\frac{m}{6}$ & $\frac{n}{0}$ & $\underset{\infty}{\infty}$ & $\frac{0}{6}$ & $\begin{array}{l}\infty \\
\dot{0} \\
\infty \\
n\end{array}$ & 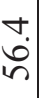 & {$\left[\begin{array}{l}n \\
i n \\
i n\end{array}\right.$} \\
\hline & $\stackrel{m}{\dot{\infty}}$ & $\begin{array}{l}n \\
\dot{\infty} \\
\dot{\infty}\end{array}$ & $\stackrel{m}{ \pm}$ & 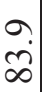 & $\mid \begin{array}{c}\infty \\
i \\
\infty\end{array}$ & {$\left[\begin{array}{l}n \\
\dot{\infty}\end{array}\right.$} & $\begin{array}{l}\dot{J}_{+} \\
\dot{\infty}\end{array}$ & $\begin{array}{l}+ \\
\dot{\infty}\end{array}$ & $\begin{array}{c}m \\
m \\
\infty\end{array}$ & $\begin{array}{l}\infty \\
i \\
\infty\end{array}$ & $\begin{array}{c}n \\
i \\
\infty\end{array}$ & $\begin{array}{l}\sigma \\
\dot{\infty}\end{array}$ & $\begin{array}{l}0 \\
\dot{\infty} \\
\infty\end{array}$ & $\frac{m}{\wedge}$ & $\begin{array}{c}n \\
\infty \\
\infty \\
n\end{array}$ & {$\left[\begin{array}{l}0 \\
n \\
i n\end{array}\right]$} \\
\hline $\begin{array}{l}+ \\
\infty \\
0 \\
0\end{array}$ & $\begin{array}{c}\checkmark \\
\text { S. } \\
0\end{array}$ & 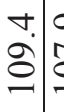 & $\frac{a}{\tilde{0}}$ & $\begin{array}{c}N \underset{1}{0} \\
\infty \\
0\end{array}$ & $\left|\begin{array}{l}0 \\
\qquad \\
0 \\
0\end{array}\right|$ & $\left(\begin{array}{c}- \\
\infty \\
0 \\
0\end{array}\right.$ & $\begin{array}{l}0 \\
\dot{0} \\
0\end{array}$ & $\begin{array}{c}+ \\
\dot{0} \\
\infty \\
\stackrel{1}{0}\end{array}$ & $\begin{array}{l}n \\
: \\
:\end{array}$ & $\begin{array}{l}+ \\
\stackrel{v}{0} \\
\varrho\end{array}$ & \begin{tabular}{l}
$n$ \\
$\stackrel{n}{0}$ \\
\hdashline
\end{tabular} & $\begin{array}{l}+ \\
\dot{\infty} \\
\stackrel{0}{0}\end{array}$ & $\begin{array}{l}\infty \\
\dot{0} \\
0\end{array}$ & $\begin{array}{c}m \\
\infty \\
\infty\end{array}$ & 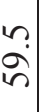 & 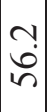 \\
\hline & 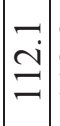 & $\stackrel{\overbrace{}}{\beth}:$ & 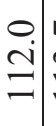 & $\stackrel{\vec{g}}{\vec{\beth}}$ & $\begin{array}{l}\stackrel{a}{a} \\
\Xi\end{array}$ & $\begin{array}{l}\Omega \\
\Xi\end{array}$ & $\begin{array}{c}\simeq \\
\beth \\
\beth\end{array}$ & $\begin{array}{l}0 \\
\stackrel{0}{=} \\
=\end{array}$ & $\underline{0}$ & $\stackrel{?}{=}$ & 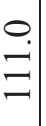 & $\begin{array}{l}\sigma \\
\tilde{\Xi}\end{array}$ & $\exists$ & $\begin{array}{l}\text { aे. } \\
\infty\end{array}$ & $\frac{7}{6}$ & $\mid \begin{array}{l}\infty \\
\dot{0} \\
n \\
n\end{array}$ \\
\hline & ت. & $\exists$ & $\begin{array}{c}\infty \\
\stackrel{0}{0} \\
=\end{array}$ & $\begin{array}{l}\varrho \\
\vdots \\
= \\
=\end{array}$ & $\mid \begin{array}{c}0 \\
\dot{0} \\
=\end{array}$ & $\stackrel{ナ}{\stackrel{\Xi}{\Xi}}$ & $\begin{array}{l}0 \\
0 \\
= \\
=\end{array}$ & $\Xi$ & \begin{tabular}{l}
$\infty$ \\
\hdashline \\
\hdashline \\
$=$
\end{tabular} & $\exists$ & \begin{tabular}{c}
$\mathfrak{N}$ \\
\hdashline \\
$=$ \\
$=$
\end{tabular} & $\begin{array}{l}\sim \\
\stackrel{m}{=}\end{array}$ & $\begin{array}{l}+ \\
\Xi \\
\Xi\end{array}$ & $\begin{array}{l}a \\
\vdots \\
\infty\end{array}$ & 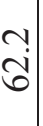 & 站 \\
\hline $\begin{array}{l}\overrightarrow{0} \\
\underline{\underline{\theta}}\end{array}$ & 三. & $\begin{array}{l}\infty \\
\stackrel{0}{0} \\
=\end{array}$ & $\begin{array}{l}\hat{0} \\
\dot{0}\end{array}$ & $\begin{array}{l}\infty \\
\vdots \\
= \\
=\end{array}$ & $\begin{array}{l}a \\
\dot{o} \\
0\end{array}$ & $\left(\begin{array}{l}0 \\
0 \\
0\end{array}\right.$ & $\begin{array}{l}0 \\
\dot{0} \\
=\end{array}$ & $\begin{array}{l}+ \\
= \\
=\end{array}$ & $\begin{array}{l}0 \\
0 \\
0 \\
=\end{array}$ & \begin{tabular}{l}
$N$ \\
\hdashline \\
$=$
\end{tabular} & 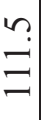 & $\begin{array}{l}n \\
\beth \\
\beth\end{array}$ & $\begin{array}{l}+ \\
\stackrel{0}{0} \\
=\end{array}$ & $\begin{array}{l}n \\
\vdots \\
\infty\end{array}$ & $\begin{array}{l}\sigma_{i} \\
\text { i }\end{array}$ & $\begin{array}{l}0 \\
\text { in } \\
\text {. }\end{array}$ \\
\hline m & Oे. & $\begin{array}{ll} \\
= & =\end{array}$ & $\begin{array}{l}\varrho \\
0 \\
=\end{array}$ & $\begin{array}{c}0 \\
\stackrel{i}{=} \\
=\end{array}$ & $\begin{array}{l}a \\
\dot{\partial} \\
0\end{array}$ & 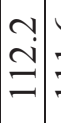 & $\begin{array}{l}0 \\
= \\
=\end{array}$ & 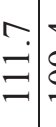 & 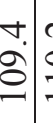 & $\begin{array}{l}N \\
0 \\
0\end{array}$ & 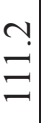 & $\begin{array}{c}\infty \\
\mathcal{I} \\
\beth\end{array}$ & $\begin{array}{l}\infty \\
\dot{0} \\
=\end{array}$ & $\begin{array}{l}\infty \\
\infty \\
\infty \\
\infty\end{array}$ & $\begin{array}{l}n \\
i \\
\text { b }\end{array}$ & in \\
\hline & 우 & $\begin{array}{l}0 \\
= \\
=\end{array}$ & $\begin{array}{c}m \\
\\
=\end{array}$ & 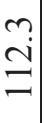 & $\begin{array}{c}1 \\
2 \\
0 \\
-\end{array}$ & $\left(\begin{array}{l}0 \\
0 \\
\hdashline\end{array}\right.$ & 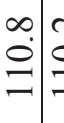 & 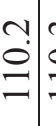 & $\begin{array}{c}n \\
\varrho \\
=\end{array}$ & $\hat{0}$ & $\begin{array}{l}\varrho \\
\vdots \\
= \\
=\end{array}$ & $\begin{array}{l}m \\
\approx \\
=\end{array}$ & ב & ○. & $\begin{array}{l}n \\
\text { ஸु }\end{array}$ & in \\
\hline & $\begin{array}{l}a \\
\dot{0} \\
=\end{array}$ & $\begin{array}{c}\overrightarrow{\mathrm{c}} \\
=\end{array}$ & 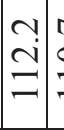 & $\begin{array}{l}r \\
\vdots \\
= \\
=\end{array}$ & $\mid \begin{array}{c}\infty \\
\dot{0} \\
0\end{array}$ & {$\left[\begin{array}{l}r \\
0 \\
\infty \\
0 \\
0\end{array}\right.$} & \begin{tabular}{l}
0 \\
\hdashline \\
$=$ \\
$=$
\end{tabular} & $\begin{array}{l}0 \\
0 \\
0 \\
=\end{array}$ & $\begin{array}{c}\mathfrak{c} \\
\stackrel{-}{=} \\
=\end{array}$ & $\begin{array}{l}\simeq \\
\exists \\
\exists\end{array}$ & $\begin{array}{c}m \\
\vdots \\
= \\
=\end{array}$ & $\stackrel{\vartheta}{\Xi}$ & $\begin{array}{l}\hat{\sigma} \\
\dot{\partial}\end{array}$ & $\begin{array}{l}\sim \\
\stackrel{D}{ } \\
\infty\end{array}$ & 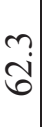 & $\begin{array}{l}0 \\
i n \\
\text { in }\end{array}$ \\
\hline $\bar{च}$ & $\begin{array}{l}\hat{0} \\
0 \\
=\end{array}$ & $\begin{array}{c}0 \\
\stackrel{1}{=} \\
\end{array}$ & $\left(\begin{array}{l}\nabla \\
\stackrel{2}{二} \\
\beth\end{array}\right.$ & $\begin{array}{l}0 \\
\dot{0} \\
= \\
=\end{array}$ & $\begin{array}{l}0 \\
\equiv \\
=\end{array}$ & 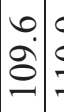 & $\begin{array}{l}\stackrel{9}{0} \\
=\end{array}$ & $\exists$ & $\begin{array}{c}r \\
\vdots \\
\vdots\end{array}$ & $\begin{array}{l}\stackrel{\nabla}{\circ} \\
\stackrel{0}{=}\end{array}$ & $\begin{array}{l}\stackrel{ナ}{\circ} \\
= \\
=\end{array}$ & $\begin{array}{c}0 \\
i \\
\beth \\
=\end{array}$ & $\begin{array}{l}n \\
\varrho \\
=\end{array}$ & $\begin{array}{l}n \\
\vdots \\
\infty\end{array}$ & त) & $\mid \begin{array}{c}n \\
i \\
i n\end{array}$ \\
\hline 二 & $\begin{array}{c}\tilde{I} \\
\Xi\end{array}$ & $\begin{array}{l}\infty \\
\stackrel{y}{=} \\
\beth\end{array}$ & $\begin{array}{l}0 \\
\stackrel{ \pm}{ \pm} \\
=\end{array}$ & $\begin{array}{l}\infty \\
\dot{0} \\
0\end{array}$ & $\begin{array}{l}a \\
\Xi \\
=\end{array}$ & $\stackrel{n}{\Xi}$ & $\begin{array}{ll}\sqsupset \\
= & =\end{array}$ & $\begin{array}{l}0 \\
\stackrel{0}{0} \\
=\end{array}$ & $\stackrel{\varrho}{\varrho}=$ & $\begin{array}{l}6 \\
\\
\end{array}$ & $\begin{array}{l}? \\
? \\
= \\
=\end{array}$ & $\stackrel{\vec{m}}{=}$ & $\begin{array}{l}n \\
= \\
=\end{array}$ & $\begin{array}{l}\infty \\
\dot{0} \\
\infty\end{array}$ & $\frac{7}{6}$ & $\begin{array}{l}\infty \\
\dot{0} \\
i\end{array}$ \\
\hline${ }^{4}$ & $\begin{array}{c}\infty \\
5 \\
0 \\
0\end{array}$ & $\begin{array}{lll}\overrightarrow{0} & 0 \\
\dot{0} & 0 \\
0 & 0\end{array}$ & $\left(\begin{array}{l}9 \\
0 \\
\infty \\
0 \\
0\end{array}\right]$ & $\begin{array}{l}\hat{\vdots} \\
0\end{array}$ & $\mid \begin{array}{c}1 \\
\infty \\
0 \\
-\end{array}$ & $\dot{0}$ & $\begin{array}{lll}0 & \\
\dot{0} & \\
0 & =\end{array}$ & \begin{tabular}{l}
$\checkmark$ \\
$\stackrel{v}{0}$ \\
\hdashline
\end{tabular} & : & $\begin{array}{l}0 \\
\dot{0} \\
0\end{array}$ & 官 & ळे & 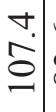 & $\begin{array}{l}0 \\
\text { ֻें } \\
\infty\end{array}$ & 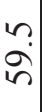 & 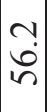 \\
\hline & $\begin{array}{c}\sigma \\
\infty \\
\infty\end{array}$ & 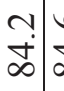 & $\mid$\begin{tabular}{c|c}
0 \\
$\dot{+}$ \\
$\infty$
\end{tabular} & $\begin{array}{c}\Omega \\
\grave{\infty}\end{array}$ & $\begin{array}{c}\sim \\
\dot{\infty} \\
\infty\end{array}$ & $\left.\begin{array}{c}a \\
\dot{\infty}\end{array}\right)$ & 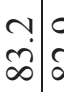 & $\begin{array}{c}\hat{s} \\
\text { i }\end{array}$ & $\vec{\infty} \dot{\infty})$ & $\begin{array}{l}v \\
\dot{\infty} \\
\dot{\infty}\end{array}$ & $\begin{array}{l}0 \\
\dot{\infty} \\
\dot{\infty}\end{array}$ & $\begin{array}{l}0 \\
\dot{\infty} \\
\infty\end{array}$ & $\begin{array}{c}+ \\
\dot{\infty} \\
\dot{\infty}\end{array}$ & $\stackrel{\sim}{\sim}$ & $\begin{array}{c}c \\
\infty \\
i\end{array}$ & 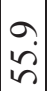 \\
\hline ?! & $=$ & $\frac{\sim}{6}$ & $\frac{7}{6}$ & $\frac{n}{6}$ & $\mid \frac{\nabla}{\vec{\sigma}}$ & $\frac{\nabla}{6}$ & 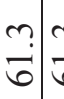 & $\frac{m}{6}$ & $\begin{array}{l}+ \\
\dot{\sigma}\end{array}$ & $\overrightarrow{0}$ & $\begin{array}{l}\infty \\
\dot{-} \\
\end{array}$ & $\infty$ & $\frac{0}{6}$ & $\begin{array}{l}\infty \\
\infty \\
\infty \\
n\end{array}$ & $\begin{array}{l}n \\
\vdots \\
n \\
n\end{array}$ & $\begin{array}{l}\hat{i} \\
i n\end{array}$ \\
\hline & & in & & 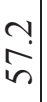 & 站 & & 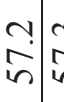 & $\begin{array}{l}? \\
\text { nn? }\end{array}$ & $\stackrel{n}{n}$ & & & $\frac{m}{i n}$ & $\begin{array}{c}n \\
\tilde{n}\end{array}$ & & & 0 \\
\hline & & & & & लि. & & $\frac{\Theta}{\dot{m}}$ & & & & & & लें & & & \\
\hline
\end{tabular}




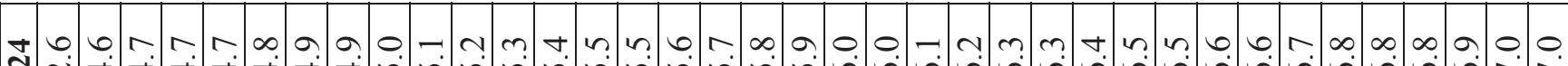

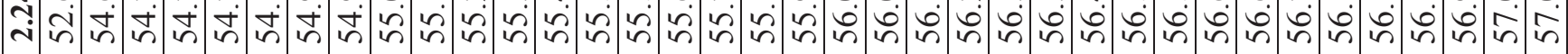

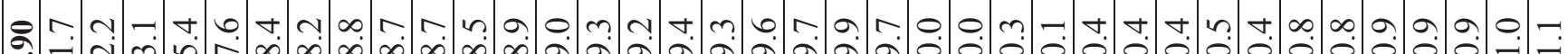

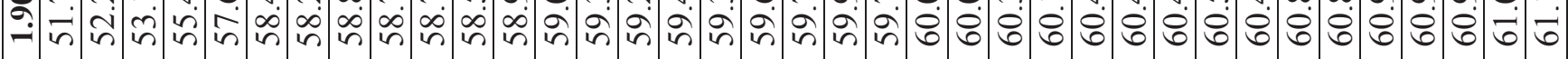

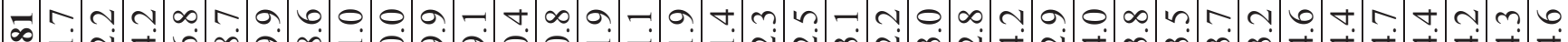

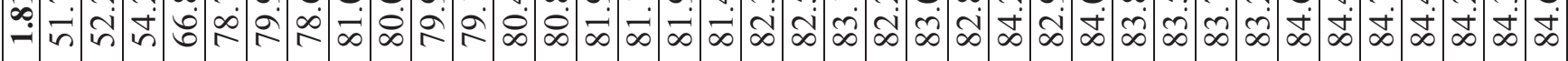

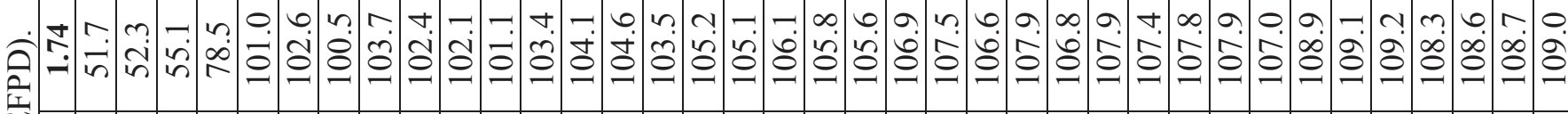

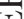

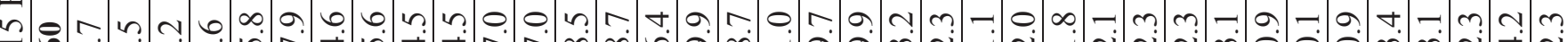
«

光

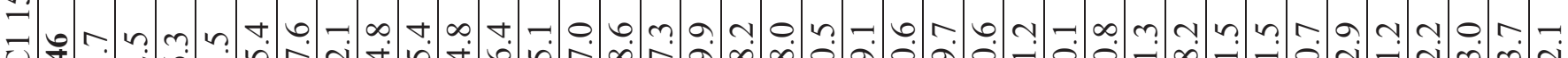

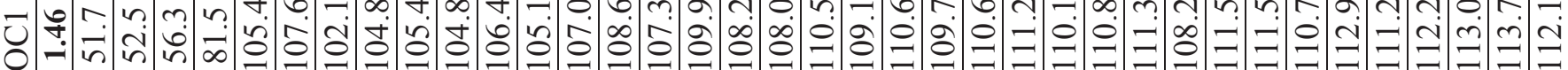

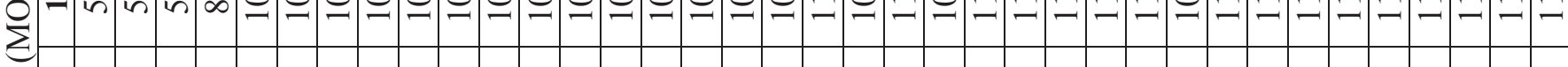

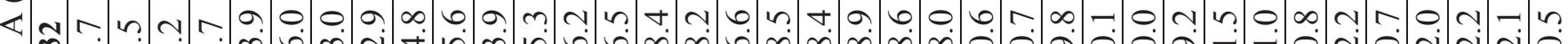
Бี (艹)

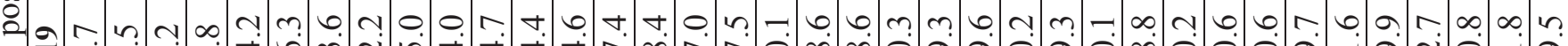

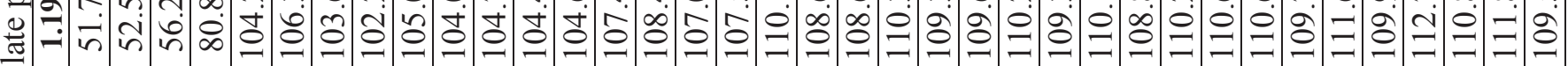

$\Xi$

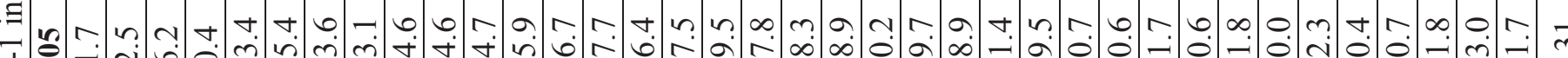
I

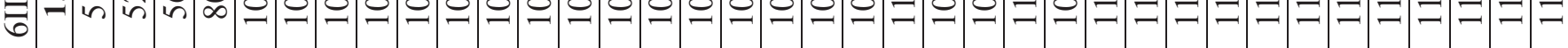

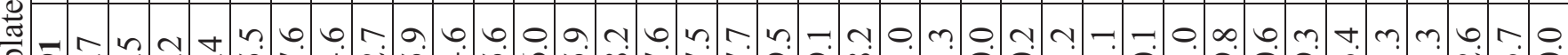

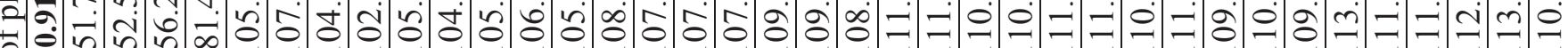

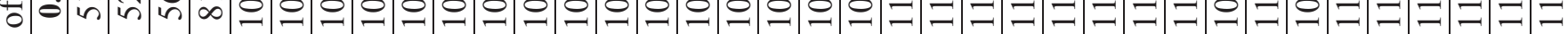
$\frac{\pi}{4}$ s N n n n a t n n 矛官 थ

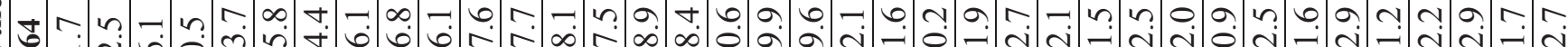

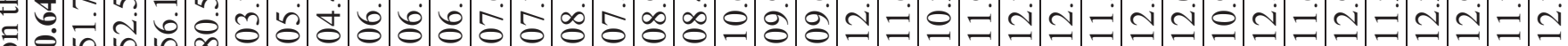

:

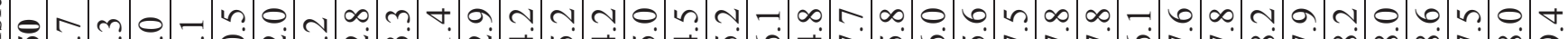
仓 o

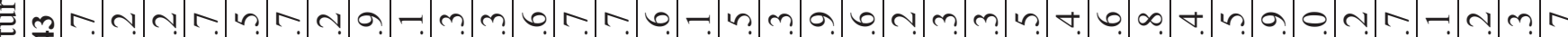
苟 in

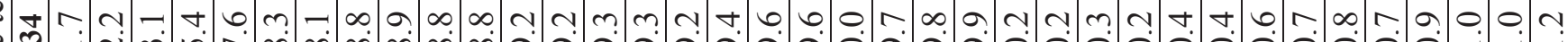

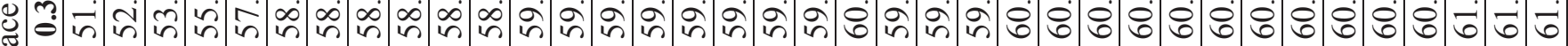
$\exists$

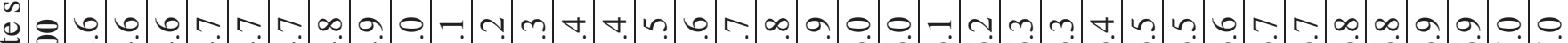
$\frac{\pi}{2}$ I

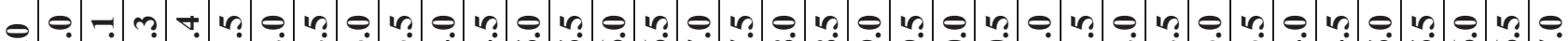

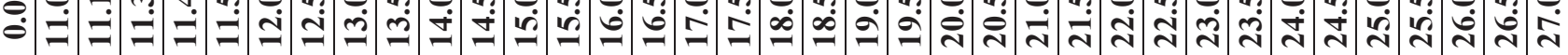




\begin{tabular}{|c|c|c|c|c|c|c|c|c|c|c|c|c|c|c|c|c|}
\hline$?$ & in & in & 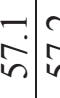 & 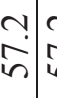 & 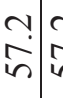 & רִ & 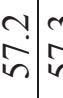 & $\begin{array}{l}m \\
\text { in }\end{array}$ & $\begin{array}{c}m \\
n \\
n\end{array}$ & m. & $\frac{m}{n}$ & $\begin{array}{l}m \\
i n\end{array}$ & $\stackrel{m}{i}$ & $\stackrel{m}{?}$ & $\frac{m}{n}$ & $\begin{array}{l}n \\
\ddot{0} \\
n\end{array}$ \\
\hline & $\frac{N}{6}$ & ד. & $\frac{n}{6}$ & 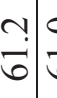 & $\frac{0}{\dot{0}}$ & & "ִ & $\frac{n}{6}$ & $\frac{\nabla}{\sigma}$ & $\frac{m}{6}$ & $\frac{n}{0}$ & $\underset{\infty}{\infty}$ & $\frac{0}{6}$ & $\begin{array}{l}\infty \\
\dot{0} \\
\infty \\
n\end{array}$ & 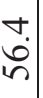 & $\begin{array}{l}0 \\
\dot{n} \\
i n\end{array}$ \\
\hline & $\begin{array}{c}\sim \\
\dot{\infty} \\
\infty\end{array}$ & $\begin{array}{l}n \\
\dot{\infty} \\
\dot{\infty}\end{array}$ & $\underset{\infty}{\stackrel{\infty}{\infty}}$ & 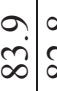 & $\begin{array}{c}\infty \\
\vdots \\
\infty\end{array}$ & $\stackrel{?}{+}$ & $\begin{array}{l}+ \\
\dot{\infty} \\
\dot{\infty}\end{array}$ & 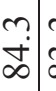 & 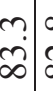 & $\begin{array}{c}\infty \\
i \\
\infty\end{array}$ & $\begin{array}{c}n \\
\vdots \\
\infty\end{array}$ & $\mid$ & $\begin{array}{c}0 \\
\dot{\infty} \\
\infty\end{array}$ & $\stackrel{\sim}{\curvearrowright}$ & $\begin{array}{c}\overrightarrow{0} \\
\dot{n}\end{array}$ & $\begin{array}{l}a \\
i n \\
i n\end{array}$ \\
\hline$\underline{g}$ & $\begin{array}{c}\checkmark \\
\text { S. } \\
0\end{array}$ & 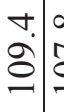 & \begin{tabular}{l}
$\infty$ \\
$\stackrel{c}{0}$ \\
\hdashline
\end{tabular} & \begin{tabular}{c|l}
-1 \\
$\infty$ \\
0 \\
0
\end{tabular} & \begin{tabular}{l}
$n$ \\
$\mathfrak{o}$ \\
\hdashline \\
\hdashline
\end{tabular} & $\begin{array}{l}0 \\
0 \\
0 \\
0\end{array}$ & $\stackrel{n}{\stackrel{n}{0}}$ & $\begin{array}{c}+ \\
\dot{0} \\
\infty \\
\stackrel{1}{0}\end{array}$ & $\begin{array}{l}1 \\
\stackrel{2}{0}\end{array}$ & $\begin{array}{l}n \\
2 \\
0 \\
\end{array}$ & $\begin{array}{l}n \\
2 \\
0 \\
c\end{array}$ & $\begin{array}{l}m \\
0 \\
\infty \\
0\end{array}$ & 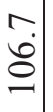 & $\begin{array}{c}N \\
\dot{\infty} \\
\infty\end{array}$ & 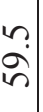 & $\begin{array}{l}7 \\
0 \\
\circ\end{array}$ \\
\hline & $\begin{array}{c}0 \\
\stackrel{1}{\Xi} \\
=\end{array}$ & 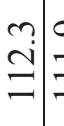 & $\stackrel{\Omega}{=}$ & $\begin{array}{ll}0 \\
\stackrel{0}{=} & 0 \\
= & \end{array}$ & $\begin{array}{l}\infty \\
\stackrel{\infty}{=} \\
=\end{array}$ & $\stackrel{\infty}{\infty}$ & 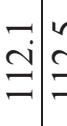 & $\stackrel{n}{=} \underset{7}{=}$ & $\hat{0}$ & $\stackrel{.}{\beth}$ & $\begin{array}{l}\stackrel{\varrho}{0} \\
= \\
=\end{array}$ & $\begin{array}{l}\infty \\
\dot{=} \\
=\end{array}$ & $\stackrel{\circ}{=}$ & $\begin{array}{l}\infty \\
\infty \\
\infty \\
\infty \\
\infty\end{array}$ & $\frac{2}{6}$ & $\begin{array}{l}0 \\
\dot{0} \\
n\end{array}$ \\
\hline & $\stackrel{?}{\Xi}$ & $\begin{array}{l}0 \\
= \\
=\end{array}$ & 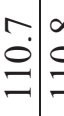 & 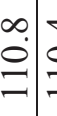 & $\begin{array}{l}\stackrel{t}{\circ} \\
=\end{array}$ & $\begin{array}{c}\mathfrak{Z} \\
=\end{array}$ & \begin{tabular}{l}
0 \\
\hdashline \\
$=$ \\
$=$
\end{tabular} & $\begin{array}{l}\infty \\
= \\
=\end{array}$ & $\begin{array}{l}\dot{0} \\
\underline{z}\end{array}$ & $=$ & $\begin{array}{c}- \\
\stackrel{0}{=} \\
=\end{array}$ & $\begin{array}{l}\nabla \\
\ddot{\sim} \\
=\end{array}$ & $\begin{array}{l}n \\
\Xi \\
=\end{array}$ & $\begin{array}{l}\infty \\
\dot{0} \\
\infty\end{array}$ & $\overrightarrow{\mathrm{i}}$ & 竞 \\
\hline$n$ & $\cong$ & $\begin{array}{l}0 \\
\stackrel{0}{0} \\
=\end{array}$ & \begin{tabular}{l|l}
0 & \\
$\dot{a}$ & \\
0 &
\end{tabular} & $\begin{array}{l}\overrightarrow{0} \\
\dot{=}\end{array}$ & $\begin{array}{l}\infty \\
\dot{a} \\
\stackrel{-}{0}\end{array}$ & $\stackrel{a}{a}$ & $\begin{array}{l}\stackrel{t}{0} \\
=\end{array}$ & $=$ & $\begin{array}{l}n \\
0 \\
=\end{array}$ & $\begin{array}{c}- \\
= \\
=\end{array}$ & $\stackrel{\nabla}{\sqsupset} \cdot$ & 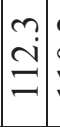 & $\begin{array}{c}\sim \\
\stackrel{1}{0} \\
=\end{array}$ & $\begin{array}{l}+ \\
\dot{0} \\
\infty\end{array}$ & $\begin{array}{l}n \\
i \\
\sigma\end{array}$ & $\begin{array}{l}n \\
i n\end{array}$ \\
\hline & $\mid$ & $\stackrel{\nabla}{=}$ & $\stackrel{\substack{0 \\
=}}{=}$ & 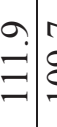 & ؛े) & $\vec{z}$ & $\stackrel{\nabla}{=}=$ & $\begin{array}{l}0 \\
= \\
=\end{array}$ & 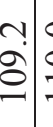 & $\begin{array}{l}0 \\
0 \\
= \\
=\end{array}$ & $\begin{array}{l}0 \\
\underline{=} \\
=\end{array}$ & 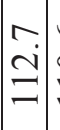 & $\begin{array}{l}0 \\
\dot{0} \\
=\end{array}$ & $\stackrel{0}{\infty}$ & $\begin{array}{l}n \\
i \\
\text { d }\end{array}$ & $\begin{array}{l}0 \\
\text { in } \\
\text {. }\end{array}$ \\
\hline & 官 & $=$ & 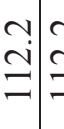 & $\underset{c}{\beth}=$ & ڤ્) & 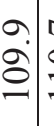 & $\begin{array}{l}\stackrel{0}{0} \\
=\end{array}$ & $\overrightarrow{0}$ & $\begin{array}{l}\mathfrak{c} \\
\stackrel{0}{=} \\
=\end{array}$ & $\begin{array}{c}\infty \\
0 \\
0\end{array}$ & $\begin{array}{l}\infty \\
\vdots \\
= \\
=\end{array}$ & $\vec{m}$ & $\begin{array}{l}\Xi \\
\Xi\end{array}$ & ڤे. & ชู & $\begin{array}{l}0 \\
\text { in } \\
\text { | }\end{array}$ \\
\hline & 足 & 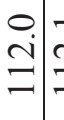 & $\underset{\beth}{\beth}$ & $\stackrel{n}{\mathfrak{0}}=$ & $\begin{array}{l}0 \\
\dot{a} \\
\dot{0}\end{array}$ & \begin{tabular}{l|l}
0 \\
$\dot{0}$ \\
$\dot{0}$ \\
0
\end{tabular} & 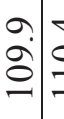 & $\begin{array}{l}+ \\
\stackrel{0}{\circ} \\
=\end{array}$ & $\stackrel{0}{\stackrel{0}{0}} \underset{ }{=}$ & $\begin{array}{l}0 . \\
\Xi \\
=\end{array}$ & 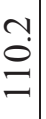 & 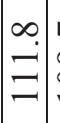 & $\stackrel{-}{\circ}$ & $\begin{array}{l}\sim \\
\vdots \\
\infty\end{array}$ & ชి & 足 \\
\hline & 号 & $\underset{\Xi}{=}$ & 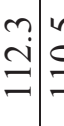 & $\begin{array}{l}n \\
0 \\
= \\
=\end{array}$ & $\stackrel{\varrho}{0}$ & 吕 & \begin{tabular}{l|l}
$\infty$ & 0 \\
0 & \\
$=$ & \\
$=$ &
\end{tabular} & 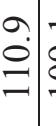 & $\vec{g}$ & $\begin{array}{l}m \\
= \\
=\end{array}$ & $\begin{array}{l}n \\
\vdots \\
= \\
=\end{array}$ & $\begin{array}{c}n \\
\\
=\end{array}$ & $\begin{array}{l}+ \\
\stackrel{\circ}{\circ} \\
=\end{array}$ & $\begin{array}{l}ナ \\
\dot{b} \\
\infty\end{array}$ & ㅎํ & $\overrightarrow{i n}$ \\
\hline & $\begin{array}{c}0 \\
\text { ci } \\
\Xi\end{array}$ & 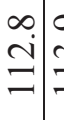 & $\stackrel{g}{=} \stackrel{2}{=}$ & 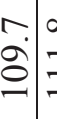 & $\begin{array}{l}\infty \\
= \\
=\end{array}$ & בn & $\stackrel{?}{=}=$ & 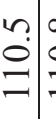 & 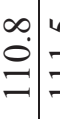 & $=$ & $\begin{array}{l}\Upsilon \\
0 \\
= \\
=\end{array}$ & $\mid \begin{array}{l}0 \\
\dot{\sim} \\
=\end{array}$ & $\begin{array}{l}\stackrel{\nabla}{\Xi} \\
\Xi\end{array}$ & & 官 & 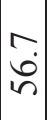 \\
\hline 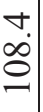 & $\begin{array}{c}r \\
\hat{0} \\
0\end{array}$ & \begin{tabular}{l|l}
$\overrightarrow{0}$ & 0 \\
$\dot{0}$ & 0 \\
0 & 0
\end{tabular} & 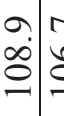 & 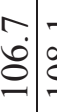 & 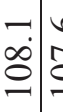 & $\begin{array}{l}0 \\
0 \\
0 \\
\end{array}$ & | & $\begin{array}{c}n \\
2 \\
0\end{array}$ & 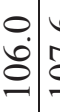 & ơ & $\begin{array}{l}0 \\
\dot{0} \\
0 \\
-\end{array}$ & $\begin{array}{l}\dot{0} \\
0 \\
0\end{array}$ & $\begin{array}{l}n \\
5 \\
0\end{array}$ & & 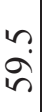 & \begin{tabular}{l}
1 \\
$\dot{0}$ \\
\hdashline
\end{tabular} \\
\hline & $\begin{array}{c}\infty \\
\infty \\
\infty\end{array}$ & $\begin{array}{cc}\Upsilon \\
\dot{\infty} \\
\infty\end{array}$ & \begin{tabular}{l|l}
0 & 0 \\
$\dot{\infty}$ & 0
\end{tabular} & $\begin{array}{c}\sigma_{\infty} \\
\infty\end{array}$ & $\begin{array}{c}\mathfrak{c} \\
\dot{\infty} \\
\dot{\infty}\end{array}$ & 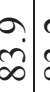 & $\begin{array}{c}\sim \\
\tilde{\infty}\end{array}$ & $\begin{array}{c}\hat{s} \\
\text { i }\end{array}$ & $\vec{\infty} \dot{\infty})$ & $\begin{array}{l}v \\
\dot{\infty} \\
\dot{\infty}\end{array}$ & $\begin{array}{l}0 \\
\dot{\infty} \\
\dot{\infty}\end{array}$ & $\mid \begin{array}{l}0 \\
\dot{\infty} \\
\infty\end{array}$ & $\begin{array}{c}+ \\
\dot{\infty}\end{array}$ & 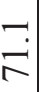 & $\begin{array}{c}c \\
\infty \\
i n\end{array}$ & $\begin{array}{l}a \\
i \\
n \\
n\end{array}$ \\
\hline $\mathrm{N}$ & $=$ & $\frac{\Upsilon}{-1}$ & త్ర & $\frac{n}{6}$ & $\frac{+}{\overrightarrow{6}}$ & $\frac{\nabla_{0}}{\sigma}$ & $\frac{m}{6}$ & $\frac{1}{6}$ & $\frac{n}{6}$ & 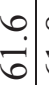 & $\begin{array}{l}\infty \\
\dot{\vec{b}}\end{array}$ & i. & $\frac{0}{6}$ & $\begin{array}{l}\infty \\
\infty \\
\infty \\
n\end{array}$ & & $\begin{array}{l}0 \\
i n \\
i n\end{array}$ \\
\hline & in & in & & ִָ & הin & & $\begin{array}{c}m \\
\tilde{n}\end{array}$ & & $m$ & $\checkmark$ & $\stackrel{t}{i}$ & 它 & in & & & $\begin{array}{l}n \\
0 \\
0 \\
n\end{array}$ \\
\hline & $\underset{\sim}{\infty}$ & & & 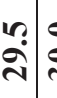 & & & $\frac{\Theta}{\dot{m}}$ & $\frac{n}{m}$ & & & & & लें & & $m$ & \\
\hline
\end{tabular}




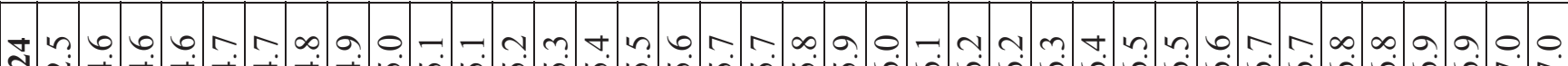
ลี ถึ่

å. -

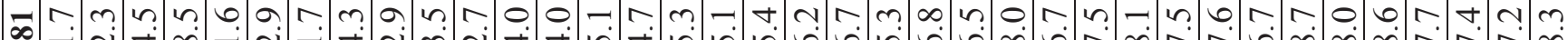

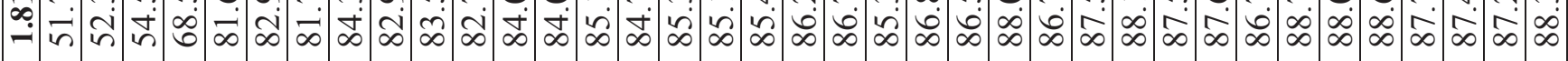

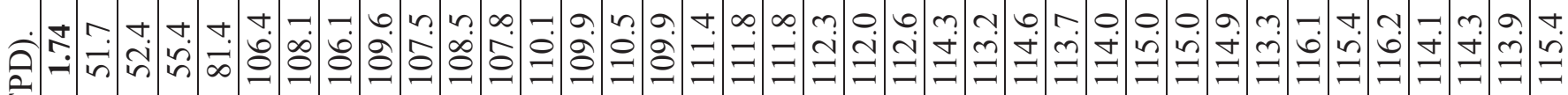

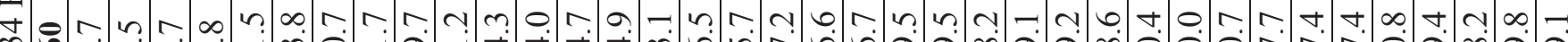

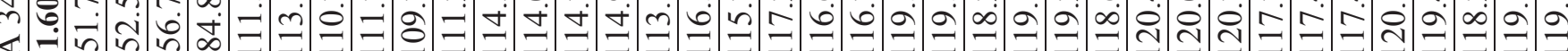

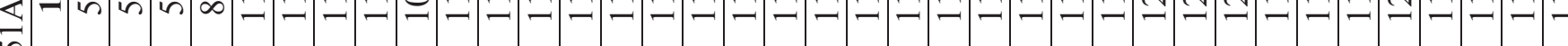

त

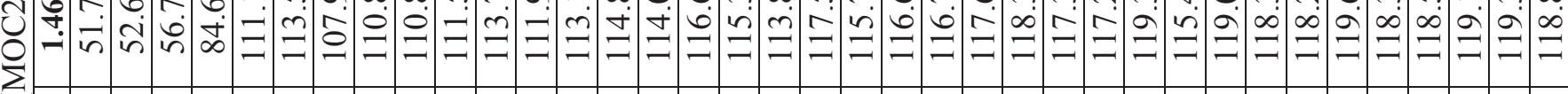

$\pi$ r n

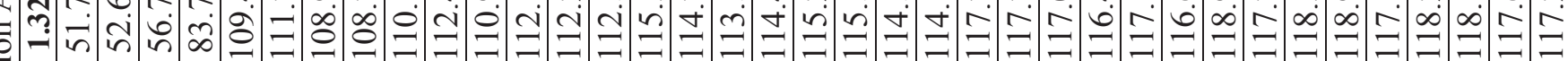

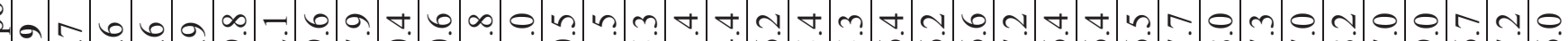

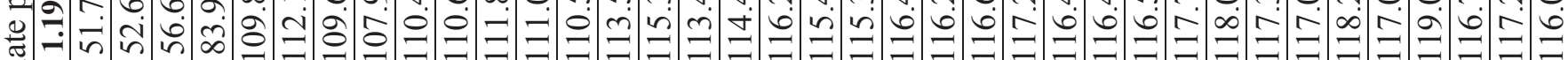

Z

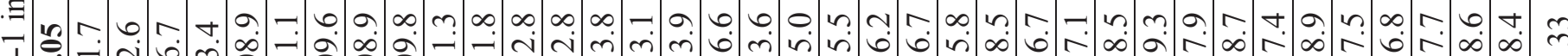
ت̈

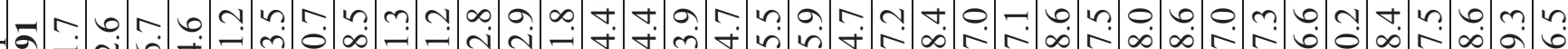

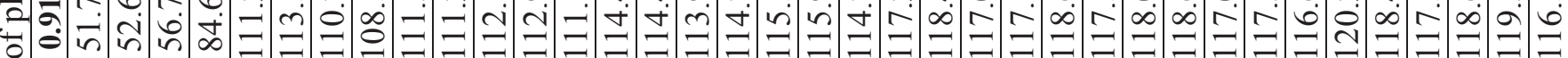
娄

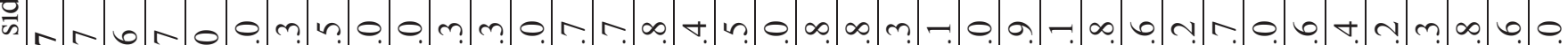

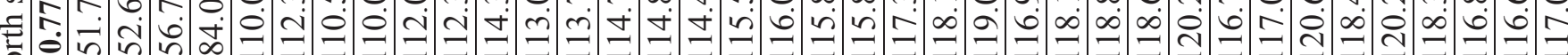
z

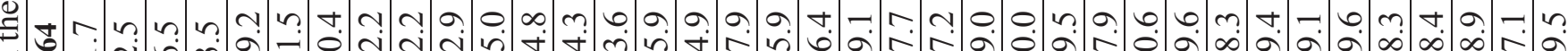

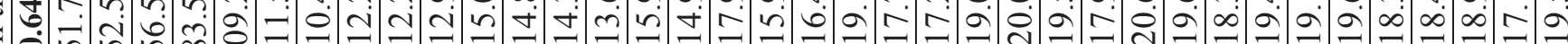
:

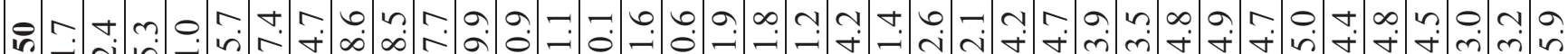

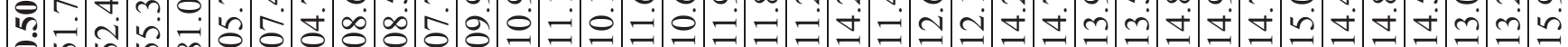
U

m r. m. n. m m

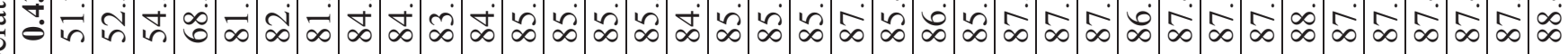

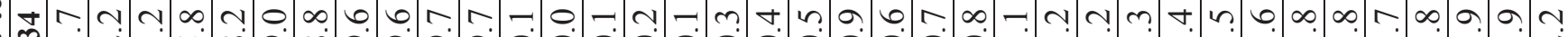

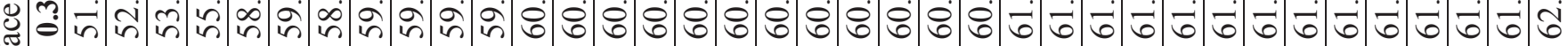

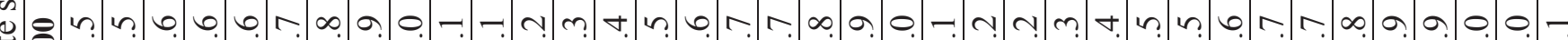
音

$\stackrel{\infty}{-}$

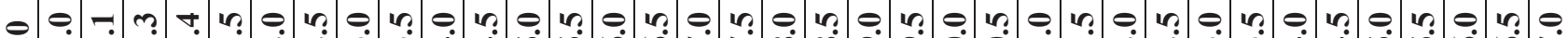

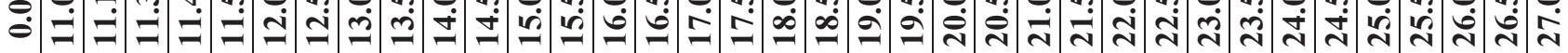




\begin{tabular}{|c|c|c|c|c|c|c|c|c|c|c|c|c|c|c|c|c|}
\hline & in & $\begin{array}{lll} & \\
& & \\
\end{array}$ & $\mid \begin{array}{l}n \\
i n \\
n\end{array}$ & & הin & in & $\begin{array}{c}m \\
i \\
n\end{array}$ & & $\begin{array}{l}\nabla \\
i\end{array}$ & 它. & $\begin{array}{l}n \\
n \\
n\end{array}$ & $\begin{array}{l}n \\
i n \\
i n\end{array}$ & & 范 & & $\begin{array}{l}\infty \\
0 \\
\bullet \\
n\end{array}$ \\
\hline & $\begin{array}{c}\sim \\
\text { Ċ}\end{array} \mid$ & 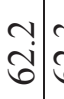 & 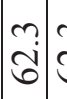 & 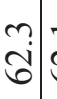 & તું & $\begin{array}{l}0 \\
i \\
i \\
\sigma\end{array}$ & $\begin{array}{l}0 \\
i \\
\text { b }\end{array}$ & $\begin{array}{c}0 \\
\text { îj }\end{array}$ & 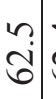 & $\begin{array}{l}+ \\
\overrightarrow{\mathrm{V}}\end{array}$ & 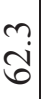 & $\begin{array}{l}\infty \\
\dot{\sigma} \\
\text { d }\end{array}$ & & ñ & & $\overrightarrow{0}$ \\
\hline & $\begin{array}{c}a \\
\infty \\
\infty\end{array}$ & \begin{tabular}{c|c}
$a$ \\
$\vdots$ \\
$\infty$ & 0 \\
$\vdots$
\end{tabular} & $\begin{array}{lll}2 & 1 \\
\infty & 2 & 2\end{array}$ & 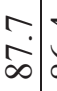 & $\begin{array}{l}\dot{0} \\
\infty \\
\infty\end{array}$ & $\begin{array}{c}m \\
\infty \\
\infty \\
\infty\end{array}$ & $\begin{array}{c}0 \\
\infty \\
\infty \\
\infty\end{array}$ & $\frac{\hat{\infty}}{\infty}$ & $\begin{array}{c}n \\
\infty \\
\infty\end{array}$ & $\begin{array}{l}n \\
\vdots \\
\infty\end{array}$ & $\begin{array}{c}\stackrel{2}{\infty} \\
\infty\end{array}$ & $\begin{array}{c}\mathcal{1} \\
\infty \\
\infty \\
\infty\end{array}$ & $\begin{array}{l}\infty \\
\dot{0} \\
\infty\end{array}$ & $\stackrel{m}{\sim}$ & $\begin{array}{l}a \\
\dot{\infty} \\
n\end{array}$ & $\begin{array}{l}t \\
\dot{\theta} \\
n\end{array}$ \\
\hline & $\begin{array}{l}\hat{m} \\
=\end{array}$ & $\stackrel{\nabla}{=}=$ & $\exists$ & $\stackrel{\vartheta}{ \pm}$ & $=$ & $\begin{array}{l}b \\
\pm \\
\Xi\end{array}$ & $\begin{array}{l}\infty \\
\dot{\sim} \\
=\end{array}$ & $\stackrel{m}{ \pm}$ & $\stackrel{m}{=}$ & $\begin{array}{l}\infty \\
\beth \\
=\end{array}$ & $\begin{array}{l}0 \\
\exists \\
=\end{array}$ & $\overrightarrow{\dot{I}}$ & & 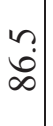 & & $\begin{array}{l}n \\
\dot{n}\end{array}$ \\
\hline & $\begin{array}{l}\infty \\
\infty \\
=\end{array}$ & \begin{tabular}{ll|l}
0 & \\
$\infty$ & \\
$=$ &
\end{tabular} & $\begin{array}{l}0 \\
\infty \\
= \\
=\end{array}$ & 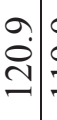 & $\stackrel{\varrho}{\varrho} \underset{z}{=}$ & $\dot{\infty}$ & $\begin{array}{l}\infty \\
\infty \\
=\end{array}$ & $\begin{array}{c}\infty \\
\infty \\
= \\
=\end{array}$ & $\begin{array}{c}n \\
\infty \\
=\end{array}$ & $\stackrel{m}{\infty}$ & $\begin{array}{l}\Upsilon N \\
\beth \\
=\end{array}$ & 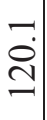 & $\begin{array}{l}\infty \\
\stackrel{-}{\beth} \\
=\end{array}$ & ナ.ं & & $\begin{array}{l}t \\
i n\end{array}$ \\
\hline & $\begin{array}{l}0 \\
\infty \\
= \\
=\end{array}$ & \begin{tabular}{l}
$\Upsilon$ \\
\hdashline \\
\hdashline
\end{tabular} & $\stackrel{n}{=}$ & ב: & $\stackrel{?}{=} \underset{\overbrace{}}{=}$ & $\stackrel{m}{=}$ & $\begin{array}{l}0 \\
\stackrel{1}{1} \\
=\end{array}$ & $\begin{array}{c}0 \\
\infty \\
0 \\
=\end{array}$ & $\begin{array}{l}\sim \\
\infty \\
=\end{array}$ & $\stackrel{-}{-\infty}$ & $\begin{array}{l}n \\
\stackrel{n}{=} \\
=\end{array}$ & $\underline{a}$ & & ナ. & & $\begin{array}{l}a \\
i n\end{array}$ \\
\hline & $\begin{array}{l}m \\
\infty \\
=\end{array}$ & $\begin{array}{l}0 \\
= \\
=\end{array}$ & ב & $\begin{array}{l}\infty \\
\vdots \\
= \\
=\end{array}$ & $\begin{array}{l}n \\
= \\
= \\
=\end{array}$ & $\underset{6}{=}$ & $\begin{array}{l}0 \\
\\
=\end{array}$ & $\begin{array}{l}n \\
\beth \\
= \\
=\end{array}$ & $\begin{array}{l}0 \\
\infty \\
=\end{array}$ & 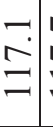 & $\stackrel{ }{\Xi}$ & $\begin{array}{l}\because \\
\infty \\
=\end{array}$ & ? & $\begin{array}{l}0 \\
\stackrel{8}{a}\end{array}$ & & $\begin{array}{l}n \\
\infty \\
n \\
n\end{array}$ \\
\hline a & 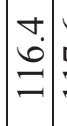 & \begin{tabular}{l}
0 \\
\hdashline \\
$=$ \\
$=$
\end{tabular} & $\stackrel{\nabla}{=}$ & $\vec{a}$ & \begin{tabular}{l}
$n$ \\
\hdashline \\
$=$ \\
$=$
\end{tabular} & 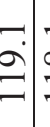 & $\vec{\infty}$ & $\stackrel{a}{\Xi}$ & $\begin{array}{l}0 \\
\dot{0} \\
=\end{array}$ & $\underset{\Xi}{\beth}$ & $\stackrel{?}{=}$ & $\begin{array}{l}0 \\
\stackrel{a}{=}\end{array}$ & $\begin{array}{l}\tilde{0} \\
=\end{array}$ & ก̊: & & 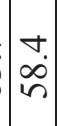 \\
\hline & $\begin{array}{l}0 \\
0 \\
= \\
=\end{array}$ & \begin{tabular}{l}
$\infty$ \\
\hdashline \\
$=$ \\
$=$
\end{tabular} & $\stackrel{0}{\stackrel{0}{a}}$ & $\begin{array}{l}\stackrel{\nabla}{\sigma} \\
\vec{\Xi}\end{array}$ & $\begin{array}{l}\infty \\
\stackrel{c}{=} \\
=\end{array}$ & 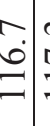 & $\stackrel{?}{\beth}$ & $\begin{array}{c}n \\
6 \\
=\end{array}$ & $\stackrel{\vartheta}{\check{I}}$ & $\stackrel{\Omega}{\Sigma}$ & $\vec{\Xi}$ & $\stackrel{\nabla}{\stackrel{\nabla}{\Xi}}$ & & 年 & & 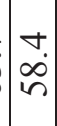 \\
\hline & $\begin{array}{l}n \\
= \\
=\end{array}$ & \begin{tabular}{l|l}
$m$ & 0 \\
$\infty$ & 0 \\
$=$ & 0
\end{tabular} & \begin{tabular}{c|c}
$\infty$ & \\
$\infty$ & \\
$=$ & 2
\end{tabular} & $\begin{array}{l}0 \\
\dot{\Xi} \\
=\end{array}$ & \begin{tabular}{l}
\multirow{2}{*}{$:$} \\
$=$ \\
$=$
\end{tabular} & $\begin{array}{c}\simeq \\
\\
=\end{array}$ & $\begin{array}{l}\stackrel{+}{\bullet} \\
= \\
=\end{array}$ & $\mid \begin{array}{l}0 \\
0 \\
0 \\
=\end{array}$ & 号 & $\begin{array}{l}\sim \\
\infty \\
= \\
=\end{array}$ & $\begin{array}{l}\stackrel{\nabla}{0} \\
\stackrel{-}{=}\end{array}$ & $\begin{array}{l}\stackrel{0}{\infty} \\
\stackrel{\infty}{=}\end{array}$ & & ळे & & $\begin{array}{l}n \\
\infty \\
n \\
n\end{array}$ \\
\hline & \begin{tabular}{l}
$\simeq$ \\
\\
$=$ \\
\hdashline
\end{tabular} & 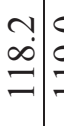 & $\begin{array}{ll}0 \\
\stackrel{5}{=} & 5\end{array}$ & $\begin{array}{l}0 \\
\dot{\Xi} \\
=\end{array}$ & $\begin{array}{l}\infty \\
= \\
=\end{array}$ & 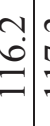 & $\begin{array}{l}m \\
\beth \\
=\end{array}$ & $\begin{array}{l}N \\
N \\
= \\
=\end{array}$ & $\begin{array}{l}n \\
0 \\
=\end{array}$ & $\begin{array}{l}? \\
= \\
=\end{array}$ & $\begin{array}{l}n \\
0 \\
= \\
=\end{array}$ & $\begin{array}{l}\stackrel{r}{\infty} \\
=\end{array}$ & \begin{tabular}{l}
$n$ \\
0 \\
$=$ \\
\hdashline
\end{tabular} & ○्. & & $\begin{array}{l}a \\
i n\end{array}$ \\
\hline & $\begin{array}{l}n \\
\beth \\
=\end{array}$ & $\overrightarrow{=}$ & 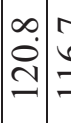 & $\stackrel{0}{0}$ & $\begin{array}{l}\infty \\
\infty \\
= \\
=\end{array}$ & $\begin{array}{l}+\infty \\
= \\
=\end{array}$ & $\stackrel{a}{\Xi}$ & $\begin{array}{c}r \\
0 \\
=\end{array}$ & $\begin{array}{l}m \\
\infty \\
=\end{array}$ & $\begin{array}{l}0 \\
\infty \\
= \\
=\end{array}$ & $\begin{array}{l}\stackrel{\nabla}{\bullet} \\
\stackrel{-}{=}\end{array}$ & $\underline{\partial}$ & & भ̊? & & $\begin{array}{l}+ \\
i \\
i n\end{array}$ \\
\hline$\stackrel{\partial}{ \pm}$ & $\exists$ & $\stackrel{+}{=}$ & $\stackrel{n}{2}=$ & $\begin{array}{l}m \\
= \\
=\end{array}$ & $\stackrel{\stackrel{ \pm}{=}}{=}$ & \pm & $\vec{\beth}$ & 足 & $\begin{array}{l}0 \\
\stackrel{0}{2} \\
=\end{array}$ & ? & $\begin{array}{l}0 \\
\dot{m} \\
=\end{array}$ & $\begin{array}{l}\infty \\
\stackrel{\dot{\Xi}}{=}\end{array}$ & & $\begin{array}{l}\infty \\
\dot{0} \\
\infty \\
\infty\end{array}$ & & $\dot{0}$ \\
\hline & $\underset{\infty}{+}$ & \begin{tabular}{l|l}
0 & \\
$\dot{\infty}$ & 0 \\
$\infty$ & 0
\end{tabular} & 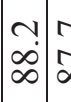 & 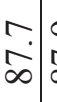 & $\begin{array}{l}0 \\
\infty \\
\end{array}$ & مِ & $\begin{array}{l}0 \\
\dot{0} \\
\infty\end{array}$ & \begin{tabular}{c}
- \\
\hdashline \\
$\infty$
\end{tabular} & $\begin{array}{c}0 \\
\dot{\infty}\end{array}$ & \begin{tabular}{c|c}
0 \\
$\dot{\infty}$ \\
$\infty$
\end{tabular} & $\begin{array}{c}0 \\
\infty \\
\infty \\
\infty\end{array}$ & $\frac{a}{\infty}$ & $\begin{array}{l}0 \\
0 \\
\infty \\
\infty\end{array}$ & $\begin{array}{c}\sim \\
\\
\end{array}$ & & $\begin{array}{l}\vec{t} \\
\dot{\bullet} \\
\sim\end{array}$ \\
\hline & ช్ & & $\mid \begin{array}{c}\vec{j} \\
\mathrm{v}\end{array}$ & $\begin{array}{l}\vec{v} \\
\vec{\jmath}\end{array}$ & 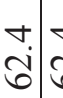 & & $m$ & & ָூ & $\infty$ & $\begin{array}{c}\hat{i} \\
\text { bis }\end{array}$ & 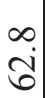 & & $\mid \begin{array}{l}n \\
n \\
\tilde{n}\end{array}$ & & $\overrightarrow{0}$ \\
\hline & & & $n$ & & $\begin{array}{c}m \\
n \\
n\end{array}$ & & $\begin{array}{l}\dot{v} \\
i \\
n\end{array}$ & $\mid \begin{array}{l} \pm \\
\tilde{n}\end{array}$ & $\begin{array}{c}n \\
n \\
n\end{array}$ & $n$ & $\begin{array}{l}n \\
n \\
n\end{array}$ & $\begin{array}{l}n \\
i n \\
i n\end{array}$ & $n$ & $\begin{array}{l}n \\
i n \\
\text { in }\end{array}$ & & $\begin{array}{l}\infty \\
0 \\
\bullet \\
n\end{array}$ \\
\hline & 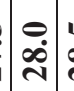 & & & 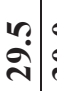 & $\stackrel{\ominus}{\stackrel{\ominus}{\mid}}$ & & & 舀 & & & & & & लि & ले & $\begin{array}{l}9 \\
9 \\
\end{array}$ \\
\hline
\end{tabular}




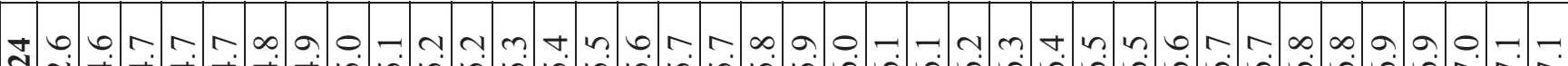

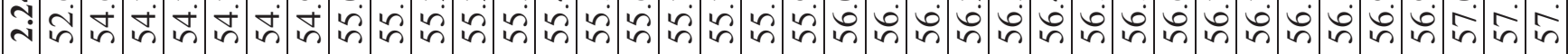

马. I.: -

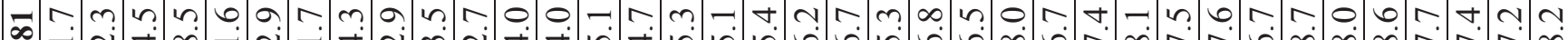

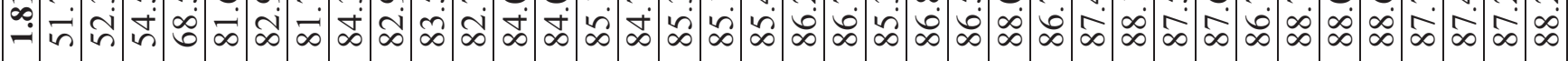

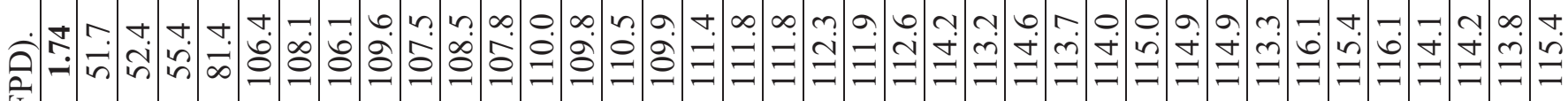

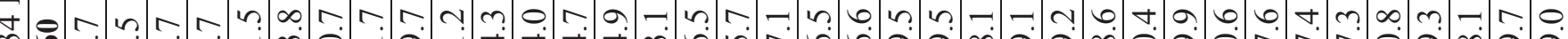
๘

$\frac{4}{n}$

v U઼

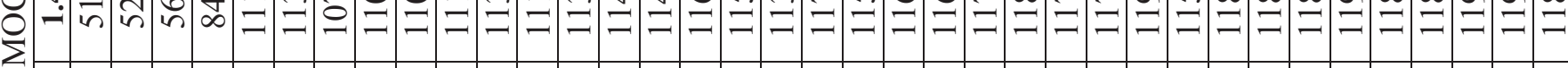

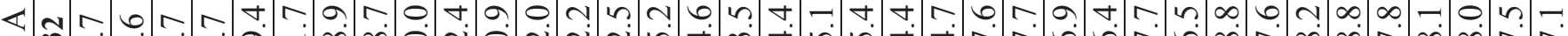

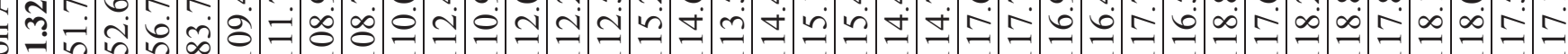
要

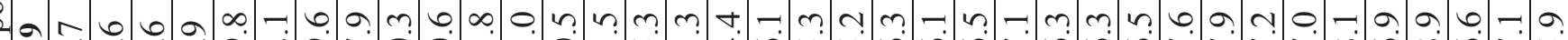

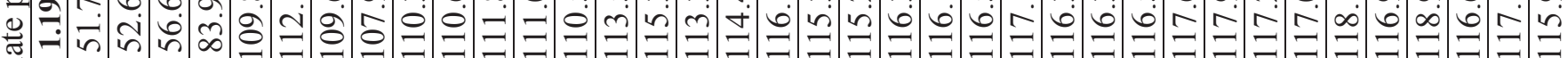
.

$\exists n$ ־ I $\frac{0}{\frac{\pi}{*}}$ - T.

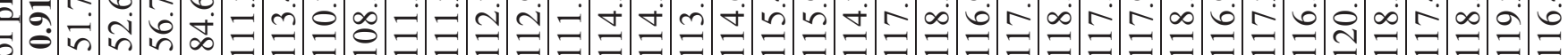

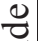

n r o r o

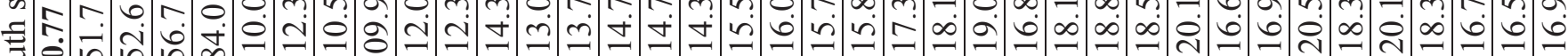

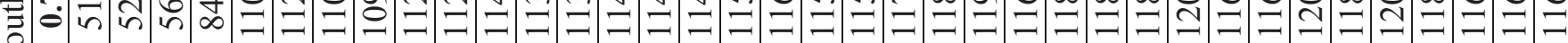

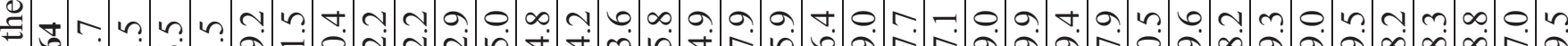

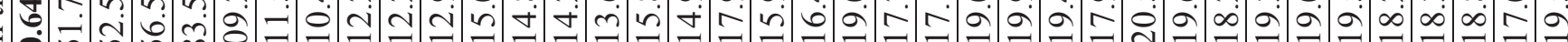

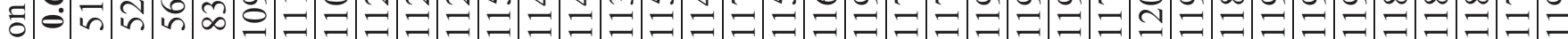

吾

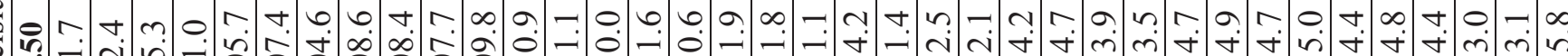

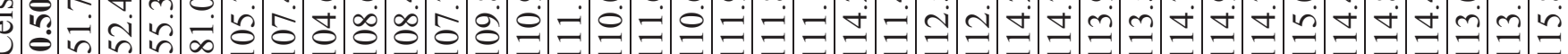
(2)

$\exists$

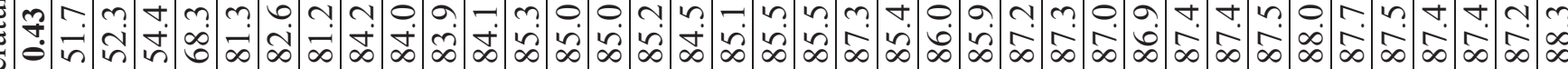

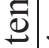

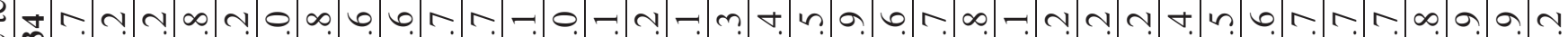

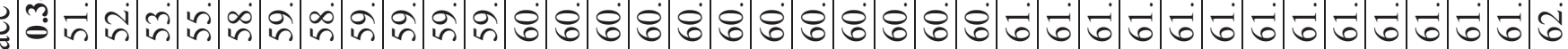
窇

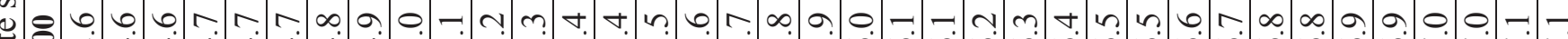
至

a.

우

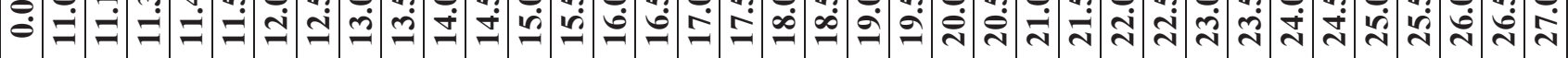




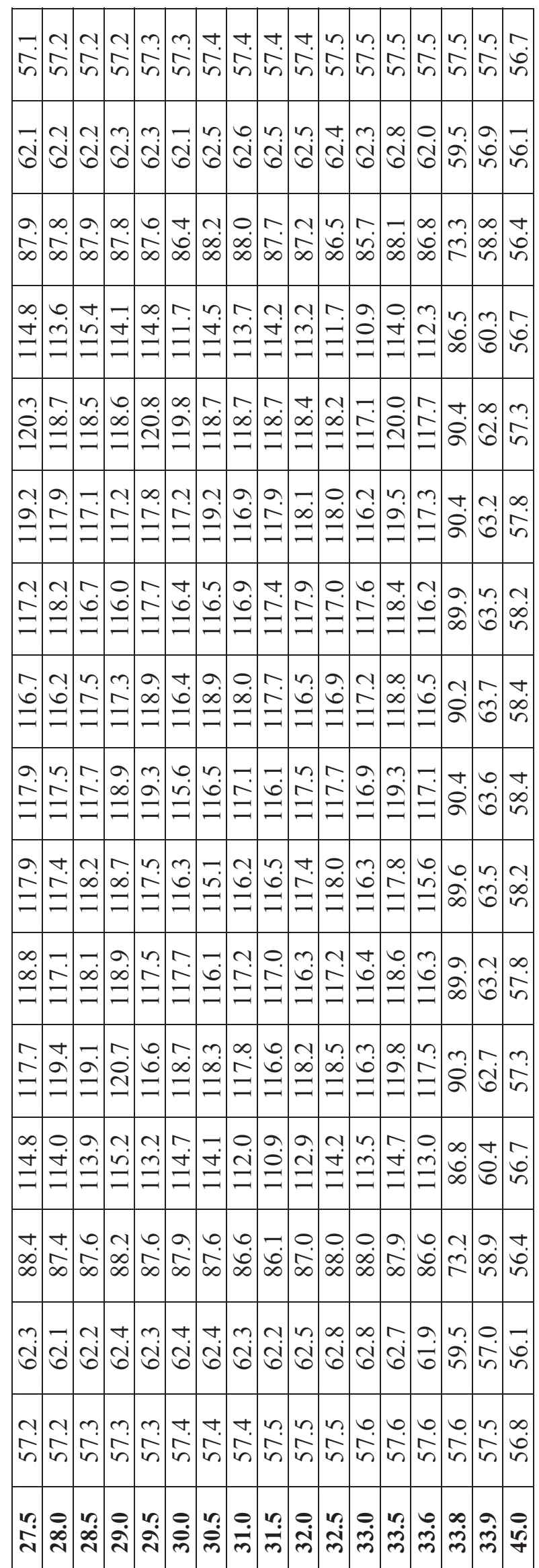




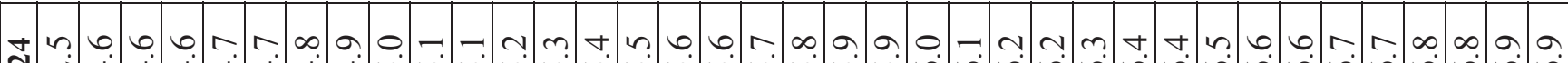

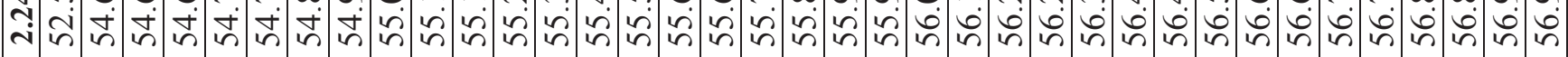

\& I.

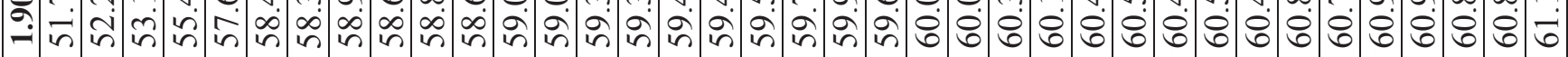

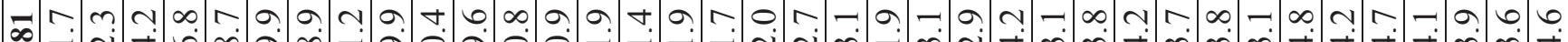
$\stackrel{\infty}{\rightarrow} \operatorname{in}$ in

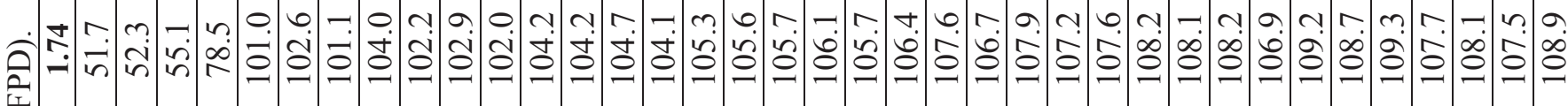
I

ம்

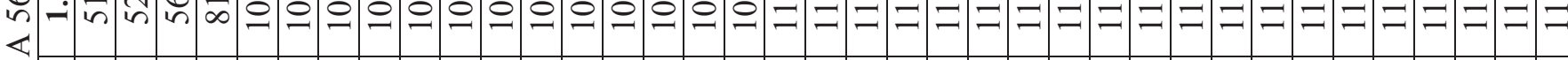

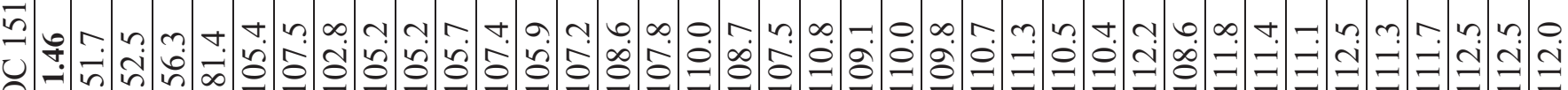
包的的 $\varangle$ 《

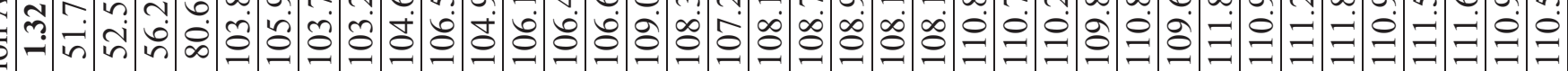
:

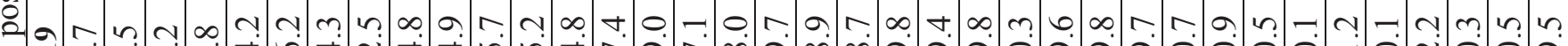
苛 寻 Z ت)

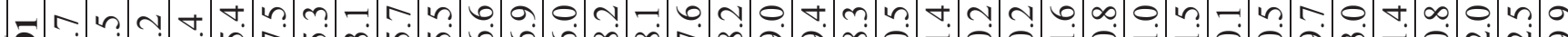

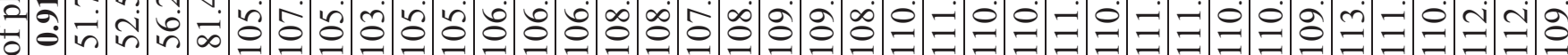
$\frac{\pi}{\pi}$

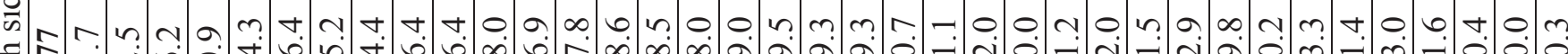

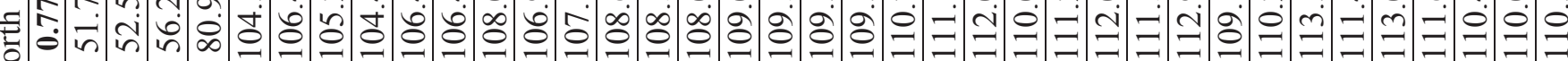
Z

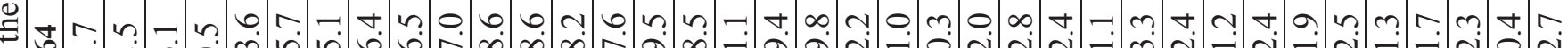
பு 2

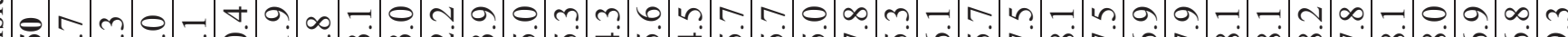

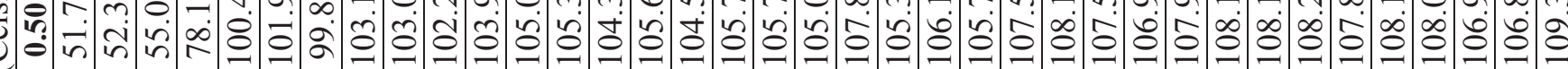
\&

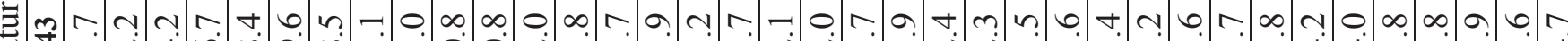

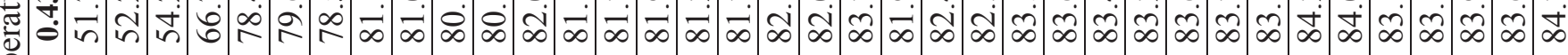
वे

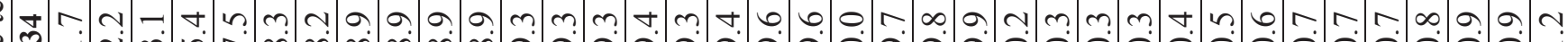

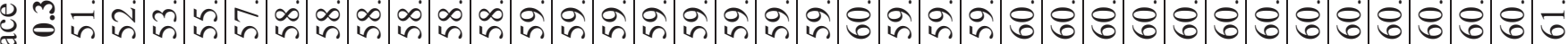

क

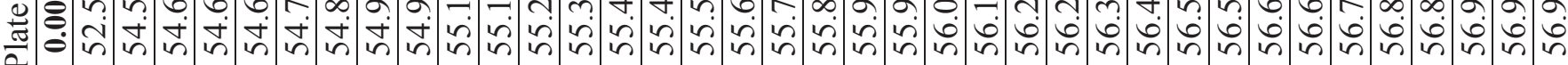
ते

-

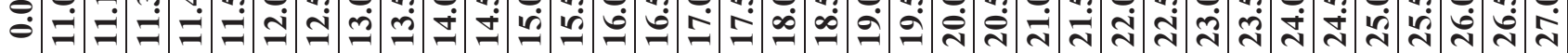




\begin{tabular}{|c|c|c|c|c|c|c|c|c|c|c|c|c|c|c|c|c|}
\hline 0. & $\begin{array}{c}0 \\
i \\
i n\end{array}$ & $\begin{array}{l}0 \\
\text { in } \\
\text { un }\end{array}$ & $\frac{7}{i n}$ & $\frac{1}{i n}$ & $\frac{n}{i n}$ & $\begin{array}{c}2 \\
\\
i n\end{array}$ & 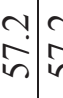 & 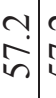 & C. & $?$ & $\frac{m}{n}$ & $\begin{array}{l}m \\
i n\end{array}$ & $\stackrel{m}{i}$ & $\stackrel{m}{?}$ & $\frac{n}{n}$ & $\begin{array}{l}n \\
\ddot{0} \\
n\end{array}$ \\
\hline & $\frac{N}{6}$ & ד. & $\frac{m}{6}$ & $\frac{n}{0}$ & 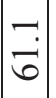 & $\frac{n}{6}$ & "ִ & : & $\frac{?}{6}$ & $\frac{\dot{v}}{6}$ & $\frac{n}{0}$ & $\frac{1}{6}$ & $\frac{0}{6}$ & $\begin{array}{c}r \\
\dot{0} \\
i n\end{array}$ & 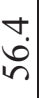 & {$\left[\begin{array}{l}n \\
i n \\
i n\end{array}\right.$} \\
\hline & $\begin{array}{c}\sim \\
\dot{\infty} \\
\infty\end{array}$ & $\begin{array}{c}\Upsilon \\
\stackrel{\infty}{\infty} \\
\end{array}$ & $\begin{array}{c}m \\
\dot{\infty}\end{array}$ & $\begin{array}{l}0 \\
\dot{\infty}\end{array}$ & $\begin{array}{c}\hat{\partial} \\
\infty\end{array}$ & $\left.\mid \begin{array}{l}0 \\
\dot{I} \\
\infty\end{array}\right]$ & $\begin{array}{l}+ \\
\dot{\infty} \\
\dot{D}\end{array}$ & 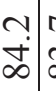 & $\vec{\infty}$ & $\vec{\infty}$ & 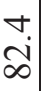 & $\mid$ & $\begin{array}{c}m \\
\infty \\
\infty\end{array}$ & $\stackrel{\square}{\therefore}$ & $\begin{array}{c}\overrightarrow{0} \\
\dot{n}\end{array}$ & $\begin{array}{l}a \\
i n \\
i n\end{array}$ \\
\hline $\begin{array}{l}m \\
0 \\
0 \\
0\end{array}$ & $\begin{array}{c}\checkmark \\
\text { ¿. } \\
0\end{array}$ & \begin{tabular}{l|l}
0 & 0 \\
$\dot{\infty}$ & 0 \\
0 & 0
\end{tabular} & 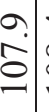 & $\begin{array}{l}+ \\
\dot{0} \\
0 \\
-\end{array}$ & r. & 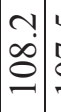 & 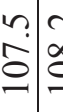 & 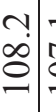 & $\underline{0}$ & $\begin{array}{l}\infty \\
\stackrel{1}{0} \\
0 \\
\end{array}$ & $\begin{array}{c}-\overrightarrow{0} \\
\stackrel{0}{0}\end{array}$ & $\stackrel{1}{\hat{\sigma}}$ & $\begin{array}{l}\sim \\
\stackrel{0}{0} \\
0\end{array}$ & $\begin{array}{c}0 \\
\dot{\infty} \\
\infty\end{array}$ & 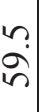 & $\begin{array}{l}n \\
0 \\
\ddots\end{array}$ \\
\hline & $\vec{\Xi}$ & 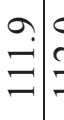 & $\begin{array}{l}0 \\
\mathfrak{i} \\
=\end{array}$ & $\begin{array}{l}\stackrel{g}{\beth} \\
\overrightarrow{=}\end{array}$ & $\overrightarrow{\ddot{n}}$ & $\begin{array}{l}0 \\
\stackrel{1}{\prime} \\
\beth\end{array}$ & ב) & $\begin{array}{c}\mathfrak{g} \\
\beth\end{array}$ & $\infty$. & ‡. & $\begin{array}{l}r \\
\stackrel{0}{=} \\
=\end{array}$ & $\begin{array}{l}\sim \\
\stackrel{y}{=} \\
=\end{array}$ & $\begin{array}{l}\exists \\
\Xi\end{array}$ & $\begin{array}{l}0 \\
\dot{0} \\
\infty\end{array}$ & $\frac{7}{6}$ & $\mid \begin{array}{l}\infty \\
\dot{0} \\
i \\
n\end{array}$ \\
\hline & $\stackrel{n}{\Xi}$ & \begin{tabular}{lll}
0 & \\
0 & \\
\hdashline & $=$
\end{tabular} & $\stackrel{\overrightarrow{0}}{\underline{\theta}}$ & $\begin{array}{l}\sim \\
\Xi \\
\Xi\end{array}$ & $\begin{array}{l}\hat{0} \\
\dot{\theta}\end{array}$ & $\left(\begin{array}{l}n \\
\check{Z} \\
\beth\end{array}\right.$ & \begin{tabular}{l}
$n$ \\
\hdashline \\
$=$
\end{tabular} & $\begin{array}{l}0 \\
= \\
=\end{array}$ & 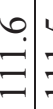 & $=$ & $\begin{array}{l}0 \\
\stackrel{0}{=} \\
=\end{array}$ & $\begin{array}{c}\infty \\
\mathcal{I} \\
\Xi \\
\beth\end{array}$ & $\begin{array}{l}0 \\
0 \\
=\end{array}$ & $\begin{array}{l}0 \\
\dot{0} \\
\infty\end{array}$ & $\overrightarrow{\mathrm{i}}$ & 綮 \\
\hline ? & : & 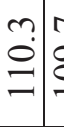 & s. & 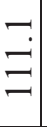 & $\stackrel{-}{\ddot{0}}$ & $\overrightarrow{0}$ & $\begin{array}{l}= \\
= \\
=\end{array}$ & $\exists$ & $=$ & $\begin{array}{c}0 \\
0 \\
0 \\
=\end{array}$ & $\begin{array}{l}n \\
= \\
=\end{array}$ & 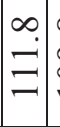 & $\begin{array}{l}\infty \\
\dot{\rho} \\
\dot{0}\end{array}$ & 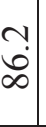 & $\begin{array}{l}n \\
i \\
\sigma\end{array}$ & $\mid \begin{array}{l}0 \\
i \\
i n\end{array}$ \\
\hline- & $\hat{\sigma}$ & $\stackrel{0}{=}$ & $\begin{array}{l}\infty \\
\stackrel{0}{=} \\
=\end{array}$ & 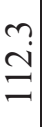 & 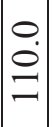 & 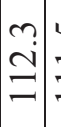 & $\stackrel{n}{=}=$ & $\stackrel{+}{=}=$ & $\overrightarrow{0}$ & $\begin{array}{l}0 \\
0 \\
0\end{array}$ & $\begin{array}{l}\varrho \\
\vdots \\
= \\
=\end{array}$ & $\begin{array}{c}\mathcal{N} \\
\mathcal{I} \\
\Xi \\
=\end{array}$ & $\begin{array}{c}\overrightarrow{0} \\
\overline{0}\end{array}$ & $\begin{array}{l}+ \\
\dot{0} \\
\infty\end{array}$ & $\begin{array}{l}n \\
i \\
\text { d }\end{array}$ & in \\
\hline & 울. & $\exists \cong$ & 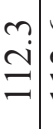 & $\begin{array}{l}0 \\
\stackrel{1}{\beth} \\
=\end{array}$ & \begin{tabular}{l}
+ \\
$\dot{\partial}$ \\
\hdashline
\end{tabular} & $\overrightarrow{0}$ & 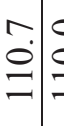 & \begin{tabular}{l}
0 \\
0 \\
\hdashline
\end{tabular} & $=$ & $?$ & $\begin{array}{l}\stackrel{0}{0} \\
= \\
=\end{array}$ & 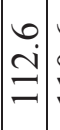 & $\begin{array}{l}0 \\
\stackrel{0}{0} \\
=\end{array}$ & $\begin{array}{l}0 \\
\dot{0} \\
\infty\end{array}$ & ๙ู & \\
\hline & $\begin{array}{c}\dot{a} \\
\dot{0} \\
=\end{array}$ & 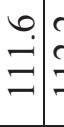 & $\begin{array}{l}\stackrel{ }{\beth} \\
\beth \\
=\end{array}$ & $\begin{array}{l}\stackrel{\varrho}{0} \\
= \\
=\end{array}$ & 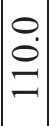 & $\mid$\begin{tabular}{c|c}
$\infty$ & 0 \\
$\infty$ \\
$\infty$ \\
0 & $\vdots$
\end{tabular} & 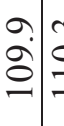 & \begin{tabular}{c}
$n$ \\
\hdashline \\
$=$
\end{tabular} & $\stackrel{\varrho}{=}=$ & $\begin{array}{l}0 \\
\Xi \\
=\end{array}$ & $\begin{array}{l}- \\
= \\
= \\
=\end{array}$ & $\stackrel{n}{\equiv}$ & $\begin{array}{l}n \\
\dot{0} \\
\dot{a}\end{array}$ & $\begin{array}{l}0 \\
\infty \\
\infty\end{array}$ & กู & $\begin{array}{l}0 \\
\hat{n} \\
\text { in }\end{array}$ \\
\hline & $\mid$ & $\stackrel{\overbrace{}}{=}$ & $\stackrel{m}{\beth}=$ & $\begin{array}{l}\varrho \\
\vdots \\
= \\
=\end{array}$ & בִ & $\left(\begin{array}{lll}r \\
\dot{a}\end{array}\right.$ & $\begin{array}{lll}\infty & \\
0 & \\
= & & \\
=\end{array}$ & \begin{tabular}{lll}
$\infty$ & \\
\hdashline
\end{tabular} & $\begin{array}{l}0 \\
\stackrel{0}{=} \\
=\end{array}$ & $\begin{array}{l}\infty \\
\stackrel{0}{0} \\
=\end{array}$ & $\begin{array}{l}- \\
\stackrel{0}{=}\end{array}$ & $\begin{array}{c}0 \\
i \\
\beth \\
=\end{array}$ & $\stackrel{a}{\partial}$ & $\vec{\infty}$ & तु) & $\frac{1}{i n}$ \\
\hline & $\begin{array}{c}\tilde{z} \\
\Xi \\
\Xi\end{array}$ & $\stackrel{\nabla}{\stackrel{\Xi}{=}}=$ & $\begin{array}{c}0 \\
\dot{ \pm} \\
=\end{array}$ & $\begin{array}{l}\overrightarrow{0} \\
\overrightarrow{=}\end{array}$ & $\stackrel{-}{\check{c}}$ & $\underline{O}$ & 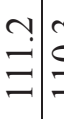 & 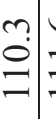 & $\begin{array}{l}0 \\
= \\
=\end{array}$ & $\begin{array}{c}0 \\
\stackrel{\Xi}{=} \\
=\end{array}$ & $\begin{array}{c}\overrightarrow{0} \\
\overrightarrow{=}\end{array}$ & $\begin{array}{l}0 \\
\ddot{1} \\
=\end{array}$ & $\begin{array}{l}a \\
\vdots \\
=\end{array}$ & & $\begin{array}{l}0 \\
\frac{0}{6}\end{array}$ & $\begin{array}{l}\infty \\
\dot{0} \\
i\end{array}$ \\
\hline${ }^{4}$ & $\mid \begin{array}{c}\infty \\
\hat{0} \\
0 \\
-\end{array}$ & \begin{tabular}{l|l}
0 & 0 \\
$\dot{s}$ & 0 \\
0 &
\end{tabular} & $\begin{array}{l}\hat{0} \\
\infty \\
0 \\
0\end{array}$ & $\begin{array}{l}0 \\
\dot{0} \\
0\end{array}$ & $\begin{array}{c}\forall \\
\dot{0} \\
\stackrel{-}{0}\end{array}$ & $\mid$\begin{tabular}{c|c}
$\infty$ & \\
$\dot{S}$ & $y$ \\
0 & $y$
\end{tabular} & $\stackrel{a}{0}$ & ‘ُ & \begin{tabular}{l|l}
$\infty$ & \\
$\dot{0}$ & \\
0 & 0 \\
0 &
\end{tabular} & $\begin{array}{l}0 \\
\dot{\infty} \\
0 \\
0\end{array}$ & $\begin{array}{c}n \\
\vdots \\
0\end{array}$ & $\left.\mid \begin{array}{l}a \\
0 \\
0 \\
0\end{array}\right]$ & $\begin{array}{l}\infty \\
\dot{0} \\
0\end{array}$ & 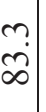 & $\begin{array}{l}n \\
\tilde{n} \\
\vdots\end{array}$ & $\begin{array}{l}1 \\
\vdots \\
n \\
n\end{array}$ \\
\hline & $\begin{array}{c}\infty \\
\infty \\
\infty\end{array}$ & $\begin{array}{ll}0 \\
\dot{5} \\
\infty\end{array}$ & & $\begin{array}{l}0 \\
\dot{\infty}\end{array}$ & $\stackrel{?}{\dot{\infty}}$ & {$\left[\begin{array}{c}0 \\
\dot{+} \\
\infty\end{array}\right]$} & $\ddot{\infty} \vec{\infty}$ & $\begin{array}{l}\infty \\
\dot{1} \\
\infty\end{array}$ & $\begin{array}{c}n \\
\infty \\
\infty\end{array}$ & $\begin{array}{l}\dot{+} \\
\dot{\infty}\end{array}$ & $\begin{array}{l}n \\
\dot{\infty} \\
\dot{\infty}\end{array}$ & $\begin{array}{c}m \\
\dot{\infty}\end{array}$ & $\begin{array}{c}-1 \\
\infty \\
\infty\end{array}$ & $\frac{0}{n}$ & $\begin{array}{c}c \\
\infty \\
i\end{array}$ & $\begin{array}{l}a \\
i \\
i n\end{array}$ \\
\hline$\frac{v}{6}$ & $=$ & $\frac{\Upsilon}{\square}$ & $\frac{\vec{\sigma}}{\dot{\sigma}}$ & $\frac{?}{6}$ & $\frac{\nabla}{\sigma}$ & $\frac{7}{\sigma}$ & $\frac{m}{6}$ & $\frac{1}{6}$ & $\frac{n}{3}$ & $\overline{6}$ & $\begin{array}{l}\infty \\
\dot{\vec{b}}\end{array}$ & - & $\begin{array}{l}0 \\
\dot{0}\end{array}$ & $\begin{array}{l}\infty \\
\infty \\
\infty \\
n\end{array}$ & $\begin{array}{l}n \\
b \\
n\end{array}$ & $\begin{array}{l}0 \\
i n \\
i n\end{array}$ \\
\hline & & & & r & $\left|\begin{array}{l}n \\
n \\
n\end{array}\right|$ & & $\begin{array}{l}N \\
\tilde{n}\end{array}$ & & & & & $\begin{array}{l}m \\
\text { in }\end{array}$ & ? & & & 0 \\
\hline & $\underset{\sim}{\infty}$ & & & & 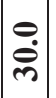 & & $\stackrel{\ominus}{m}$ & & & & & & लें & & $m$ & \\
\hline
\end{tabular}




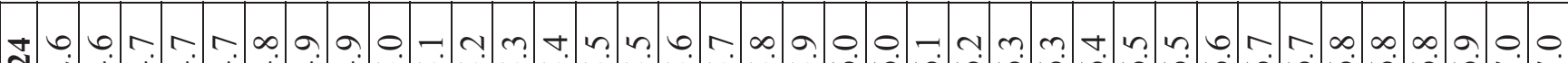

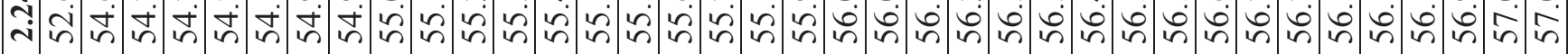

g r.

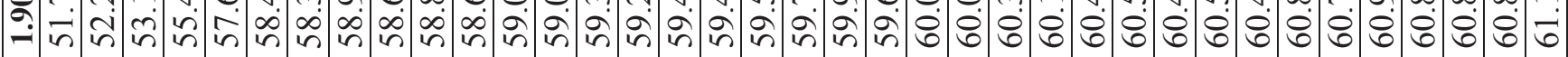

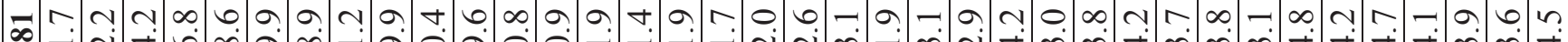

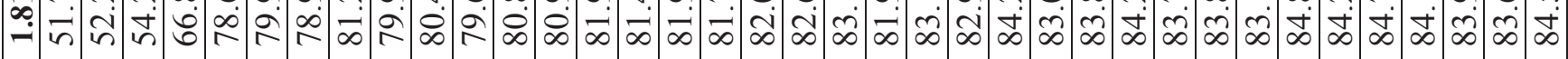

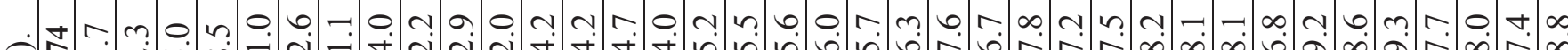

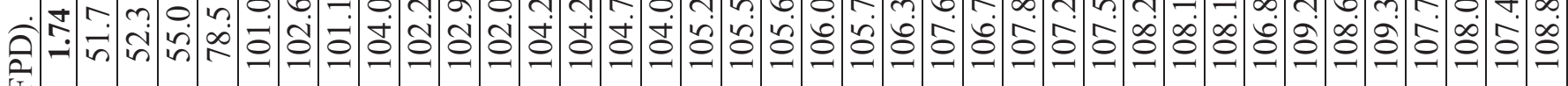
空

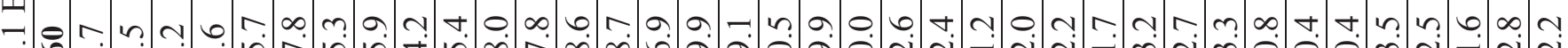
ம்

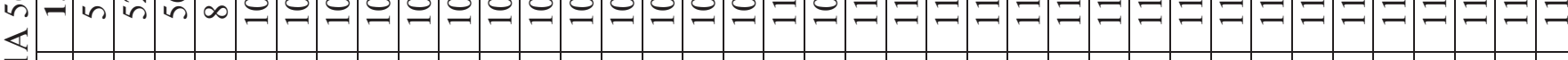

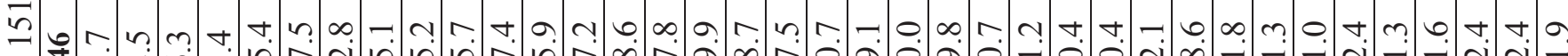

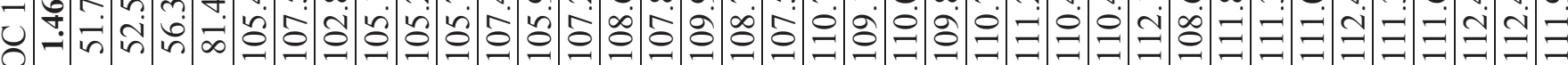

开

« N n n 0 .

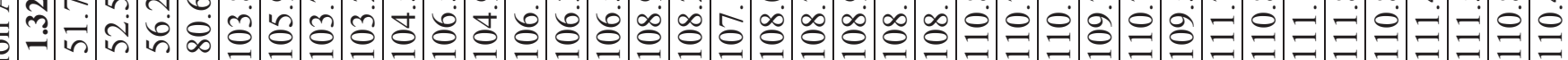

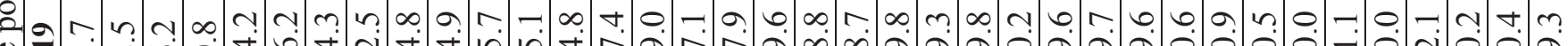
奇

.尹

Z ت)

$\frac{\pi}{3}$

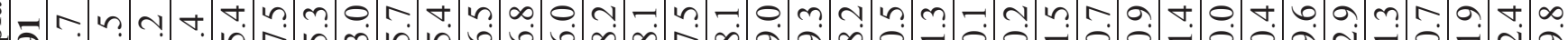

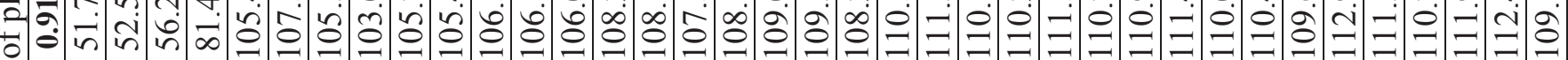
$\frac{\pi}{0}$

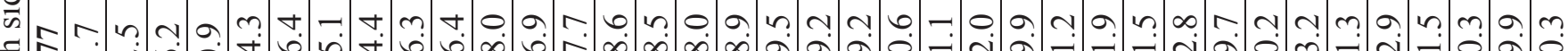

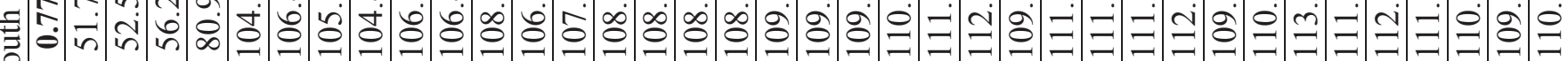

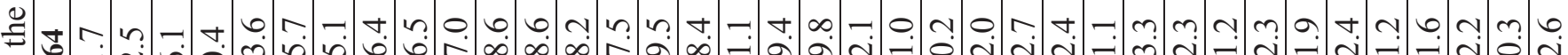

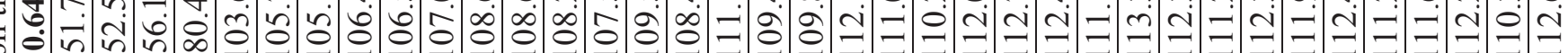
?ִ

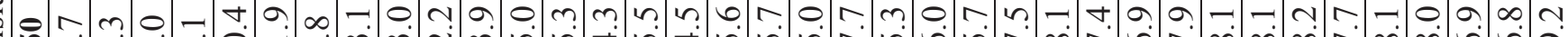

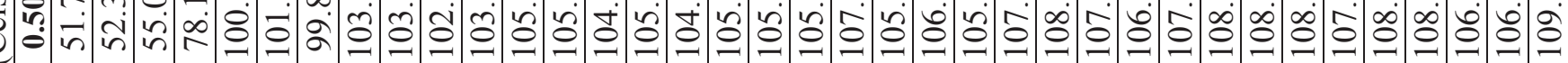
¿ै

m r cu r t 0 n

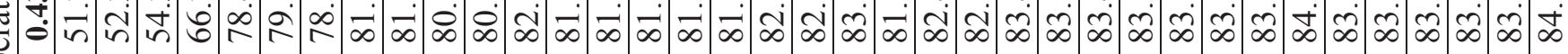

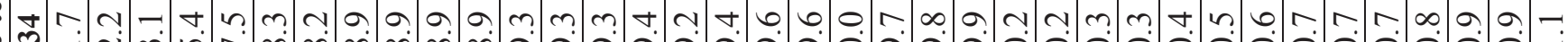
\&

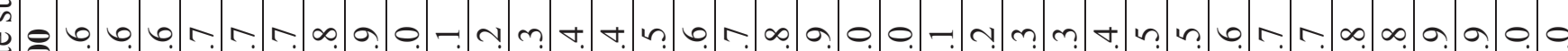

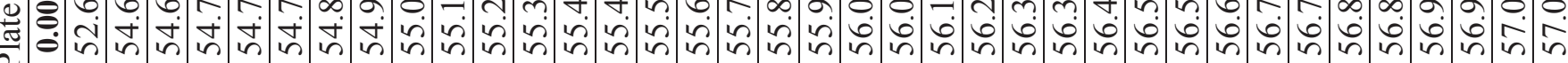
$\dot{\sim}$

$0=$ $\frac{0}{\pi}$

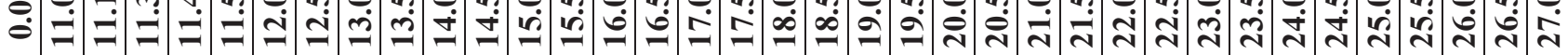




\begin{tabular}{|c|c|c|c|c|c|c|c|c|c|c|c|c|c|c|c|c|}
\hline$?$ & in & in & 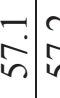 & 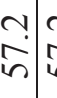 & 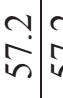 & 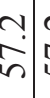 & 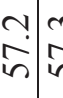 & $\begin{array}{l}m \\
\text { in }\end{array}$ & $\begin{array}{c}m \\
n \\
n\end{array}$ & $\begin{array}{c}m \\
? \\
n\end{array}$ & $\frac{m}{n}$ & $\begin{array}{l}m \\
i n\end{array}$ & $\stackrel{m}{i}$ & $\stackrel{m}{?}$ & $\frac{m}{n}$ & $\begin{array}{l}n \\
\ddot{0} \\
n\end{array}$ \\
\hline & $\frac{N}{6}$ & ד. & $\frac{n}{6}$ & 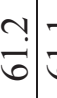 & 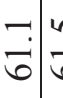 & & "ִ & $\frac{n}{6}$ & $\frac{\nabla}{6}$ & $\frac{\nabla}{\dot{\sigma}}$ & $\frac{\mathfrak{c}}{\mathfrak{0}}$ & $\frac{1}{6}$ & $\begin{array}{l}\dot{0} \\
\dot{8}\end{array}$ & $\begin{array}{c}r \\
\dot{0} \\
i n\end{array}$ & 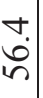 & $\begin{array}{l}0 \\
\dot{n} \\
i n\end{array}$ \\
\hline & $\begin{array}{c}\sim \\
\dot{\infty} \\
\infty\end{array}$ & 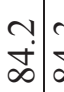 & 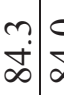 & $\begin{array}{l}0 \\
\dot{\infty} \\
\dot{\infty}\end{array}$ & $\begin{array}{l}\hat{j} \\
\infty \\
\infty\end{array}$ & $\begin{array}{l}b \\
\dot{+} \\
\dot{\infty}\end{array}$ & $\begin{array}{c}m \\
\dot{\infty} \\
\end{array}$ & 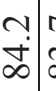 & $\vec{\infty} \dot{\infty}$ & $\begin{array}{c}0 \\
\dot{\infty} \\
\infty\end{array}$ & $\left.\begin{array}{c}n \\
\vdots \\
\infty\end{array}\right]$ & $\mid$ & $\begin{array}{c}m \\
\infty \\
\infty\end{array}$ & $\stackrel{0}{i}$ & $\begin{array}{c}\overrightarrow{0} \\
\dot{n}\end{array}$ & $\begin{array}{l}a \\
i n \\
i n\end{array}$ \\
\hline & $\begin{array}{c}n \\
\stackrel{0}{0} \\
0\end{array}$ & \begin{tabular}{l|l}
0 & 0 \\
$\infty$ & 0 \\
0 & 0 \\
0 & 0
\end{tabular} & $\begin{array}{c}\infty \\
\dot{c} \\
\\
-\end{array}$ & $\begin{array}{lll}m & \\
\infty & \\
0 & & \\
0 & \end{array}$ & 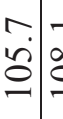 & $\overrightarrow{0}$ & $\stackrel{+}{\stackrel{t}{0}}$ & $\begin{array}{c}\overrightarrow{0} \\
\infty \\
0 \\
0\end{array}$ & $\begin{array}{c}0 \\
\hat{0} \\
\underline{0}\end{array}$ & ç. & $\begin{array}{l}0 \\
\dot{0} \\
0\end{array}$ & $\begin{array}{c}r \\
\hat{\sigma}\end{array}$ & $\begin{array}{c}- \\
\dot{0} \\
0\end{array}$ & $\begin{array}{c}\stackrel{\alpha}{\infty} \\
\infty\end{array}$ & $\begin{array}{l}n \\
n \\
n\end{array}$ & $\begin{array}{l}0 \\
0 \\
0 \\
n\end{array}$ \\
\hline & $\begin{array}{c}0 \\
\stackrel{1}{ } \\
=\end{array}$ & $\begin{array}{l}\infty \\
\exists \\
=\end{array}$ & $\begin{array}{l}\Omega \\
= \\
=\end{array}$ & $\begin{array}{ll}\infty & \\
= & \\
= & \end{array}$ & $\stackrel{0}{\stackrel{0}{=}}=$ & $\stackrel{9}{=}$ & 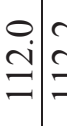 & $\begin{array}{ll}\mathfrak{y} & \\
& 7\end{array}$ & N & $\begin{array}{l}0 \\
= \\
=\end{array}$ & $\begin{array}{l}0 \\
0 \\
0 \\
=\end{array}$ & $\stackrel{-}{\stackrel{m}{=}}$ & $\begin{array}{l}0 \\
\Xi \\
=\end{array}$ & $\stackrel{\infty}{\infty}$ & o. & $\begin{array}{l}0 \\
\dot{0} \\
n\end{array}$ \\
\hline & 足: & \begin{tabular}{l}
$n$ \\
\hdashline \\
\hdashline
\end{tabular} & $\begin{array}{l}0 \\
\stackrel{0}{=}\end{array}$ & 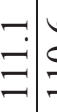 & $\begin{array}{l}0 \\
\stackrel{0}{=} \\
=\end{array}$ & 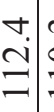 & \begin{tabular}{l}
$?$ \\
\hdashline \\
$=$
\end{tabular} & $=$ & $\underbrace{+}$ & $\underbrace{+}_{\beth}$ & $\begin{array}{l}\Omega \\
\grave{a}\end{array}$ & i․ & $\begin{array}{l}0 \\
\dot{0} \\
=\end{array}$ & $\begin{array}{l}n \\
\infty \\
\infty\end{array}$ & $\overline{\mathrm{i}}$ & in \\
\hline$t$ & $\cong$ & \begin{tabular}{l}
$\Upsilon$ \\
\hdashline \\
\hdashline
\end{tabular} & $\begin{array}{l}0 \\
\dot{a} \\
\stackrel{0}{0}\end{array}$ & $=$ & $\begin{array}{l}0 \\
\stackrel{0}{=} \\
=\end{array}$ & $\begin{array}{l}0 . \\
0 \\
0\end{array}$ & \begin{tabular}{l}
$n$ \\
\hdashline \\
$=$
\end{tabular} & 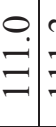 & $=$ & $\begin{array}{l}? \\
0\end{array}$ & 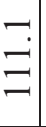 & $\exists$ & $\begin{array}{l}0 \\
\dot{8} \\
0\end{array}$ & $\vec{\vdots}$ & $\begin{array}{l}n \\
i \\
\sigma\end{array}$ & $\mid \begin{array}{l}n \\
n \\
n\end{array}$ \\
\hline 0. & 今. & $\begin{array}{l}\vdots \\
\vdots \\
=\end{array}$ & 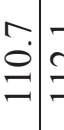 & 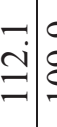 & 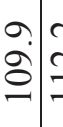 & 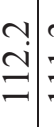 & $\stackrel{?}{=}=$ & $\stackrel{?}{=}$ & $\begin{array}{l}0 \\
0 \\
= \\
=\end{array}$ & $\begin{array}{c}+ \\
\stackrel{0}{*} \\
=\end{array}$ & $\begin{array}{l}\infty \\
0 \\
\vdots \\
=\end{array}$ & $\begin{array}{c}0 \\
\stackrel{1}{c} \\
= \\
=\end{array}$ & $\begin{array}{l}0 \\
\stackrel{0}{0} \\
=\end{array}$ & $\begin{array}{l}? \\
\stackrel{0}{0} \\
\infty\end{array}$ & 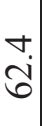 & 吕 \\
\hline & $\begin{array}{l}a \\
\varrho \\
=\end{array}$ & $\stackrel{0}{=} \underset{\beth}{=}$ & 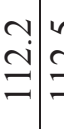 & $\stackrel{n}{=} \underset{=}{=}$ & 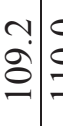 & $\begin{array}{lll}0 & 0 \\
0 & \\
= & & \end{array}$ & $\begin{array}{l}0 \\
\dot{0} \\
= \\
=\end{array}$ & $\begin{array}{ll}\infty & \\
\dot{a} & 0\end{array}$ & $\stackrel{a}{\underline{\theta}}$ & $\exists$. & $\begin{array}{l}n \\
\vdots \\
=\end{array}$ & $\mid$ & $\begin{array}{l} \pm \\
\stackrel{0}{\Xi} \\
=\end{array}$ & $\begin{array}{l}0 \\
\dot{0} \\
\infty\end{array}$ & \begin{tabular}{l}
+ \\
\multirow{\sigma}{*}{}
\end{tabular} & $\begin{array}{l}0 \\
\text { in } \\
\text { | }\end{array}$ \\
\hline & 文 & $=$ & 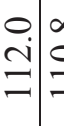 & \begin{tabular}{l}
$\infty$ \\
$\vdots$ \\
\hdashline \\
$=$
\end{tabular} & \begin{tabular}{l|l}
$\infty$ & \\
$\dot{a}$ & \\
0 &
\end{tabular} & \begin{tabular}{l|l}
0 & 0 \\
$\dot{0}$ & 0 \\
0 & 0
\end{tabular} & \begin{tabular}{l|l}
$\infty$ & \\
$\dot{0}$ & \\
0 &
\end{tabular} & 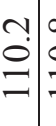 & $\begin{array}{l}\infty \\
\stackrel{0}{0} \\
=\end{array}$ & $\underset{\exists}{\exists}$ & $\stackrel{\varrho}{\grave{\partial}}$ & 工 & $\overrightarrow{8}$ & $\begin{array}{l}\infty \\
\infty \\
\infty\end{array}$ & 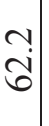 & \\
\hline & 足: & $\stackrel{\nabla}{\Xi}=$ & $\begin{array}{c}\mathfrak{N} \\
\\
=\end{array}$ & \begin{tabular}{l}
$\infty$ \\
\hdashline \\
$=$
\end{tabular} & $\exists$ & $\begin{array}{ll}0 & \\
\vdots \\
\vdots\end{array}$ & 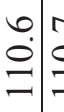 & $\stackrel{0}{\underline{\theta}}$ & 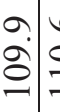 & $\begin{array}{l}0 \\
0 \\
= \\
=\end{array}$ & $\begin{array}{l}0 \\
\stackrel{0}{=} \\
=\end{array}$ & $\begin{array}{l}\Im \\
\Xi \\
\Xi\end{array}$ & $\begin{array}{l}\infty \\
\dot{\rho} \\
\stackrel{0}{ }\end{array}$ & $\vec{\emptyset}$ & $\begin{array}{c}0 \\
\text { तु }\end{array}$ & $\frac{1}{i n}$ \\
\hline a. & $\begin{array}{c}0 \\
\text { ב } \\
=\end{array}$ & 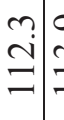 & 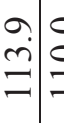 & 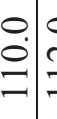 & $\begin{array}{ll}0 & \\
\stackrel{1}{=} & =\end{array}$ & $\stackrel{n}{\beth}=$ & 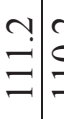 & 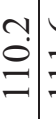 & $\begin{array}{l}0 \\
= \\
=\end{array}$ & a & $\begin{array}{l}0 \\
\stackrel{0}{=} \\
=\end{array}$ & & $\begin{array}{l}\infty \\
0 \\
0 \\
=\end{array}$ & $\begin{array}{l}\nabla_{0} \\
\dot{0}\end{array}$ & $\begin{array}{l}0 \\
\frac{0}{6}\end{array}$ & $\begin{array}{l}0 \\
\dot{0}\end{array}$ \\
\hline 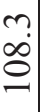 & $\begin{array}{c}r \\
\hat{0} \\
0\end{array}$ & \begin{tabular}{l|l}
0 & 0 \\
$\dot{s}$ & 0 \\
0 &
\end{tabular} & \begin{tabular}{l|l}
$\infty$ & 0 \\
$\infty$ & 0 \\
0 & \\
0 &
\end{tabular} & $\begin{array}{l}\varrho \\
\varrho \\
\varrho\end{array}$ & 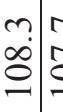 & $\hat{0}$ & 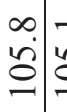 & ڤُ) & $\stackrel{0}{\circ}$ & o. & $\begin{array}{c}+ \\
\dot{s} \\
0 \\
-\end{array}$ & $\begin{array}{l}\infty \\
0 \\
0\end{array}$ & $\stackrel{0}{0}$ & & 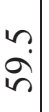 & $\left|\begin{array}{l}1 \\
0 \\
n \\
n\end{array}\right|$ \\
\hline 0 & $\begin{array}{c}\infty \\
\infty \\
\infty\end{array}$ & $\begin{array}{l}\sigma \\
\hat{\infty} \\
0\end{array}$ & $\begin{array}{l}0 \\
\dot{+} \\
\dot{\infty}\end{array}$ & $\begin{array}{l}0 \\
\dot{\infty} \\
\dot{\infty}\end{array}$ & $\begin{array}{c}m \\
\dot{\infty}\end{array}$ & $\stackrel{\infty}{\infty}$ & $\dot{\infty} \vec{\infty}$ & & $\ddot{\infty}$ & $\begin{array}{l}\dot{+} \\
\dot{\infty}\end{array}$ & 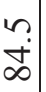 & $\begin{array}{c}m \\
\dot{\infty}\end{array}$ & $\begin{array}{c}0 \\
\dot{\infty} \\
\infty\end{array}$ & $\frac{0}{n}$ & $\begin{array}{c}- \\
\infty \\
n\end{array}$ & $\begin{array}{l}a \\
i \\
i n\end{array}$ \\
\hline ?! & $=$ & ד. & $\frac{n}{3}$ & $\frac{n}{6}$ & $\frac{\nabla}{\dot{\sigma}}$ & $\frac{+}{\dot{\sigma}}$ & $\frac{N}{6}$ & \begin{tabular}{c}
$c$ \\
\hdashline \\
\end{tabular} & $\nabla$ & $\frac{7}{6}$ & $\begin{array}{l}\infty \\
\dot{0} \\
\end{array}$ & $\frac{7}{6}$ & 9 & & $\checkmark$ & 5 \\
\hline & in & & & $\begin{array}{c}c \\
n \\
n\end{array}$ & $\begin{array}{c}m \\
n \\
n\end{array}$ & & $\begin{array}{c}m \\
\tilde{n}\end{array}$ & & & & $\begin{array}{l}t \\
i \\
i n\end{array}$ & 音 & 竞 & & & $\begin{array}{l}n \\
0 \\
n\end{array}$ \\
\hline & $\underset{\sim}{\infty}$ & & & ڤి: & & & $\frac{\Theta}{\dot{m}}$ & & & & & & $m$ & & $m$ & \\
\hline
\end{tabular}




\section{REFERENCES}

1. "Experiment Control Plan for the AFIP-6 MKII Fuel Irradiation in the ATR," PLN-3699, Revision 2, August, 2011.

2. J. W. Nielsen, G. S. Chang. "As-Run Neutronic Analysis for the AFIP-6 MKII Experiment Irradiated in the Center Flux Trap of the ATR, Cycle 151A,” ECAR-XXXX, June 2012.

3. N. E. Woolstenhulme, “AFIP-6 MKII First Cycle Report,” INL/EXT-12-25170, March 2012.

4. RERTR Project Personnel, "RERTR AFIP-6 MKII Irradiation Experiment in the Advanced Test Reactor: AsBuilt Data Package,” AFIP-6, Job ID 3826809, February 2012.

5. D. M. Wachs, "Hydraulic Testing of the AFIP Irradiation Vehicle for the ATR Center Flux Trap Position," ECAR-99, October 2007.

6. N. E. Woolstenhulme, P. G. Medvedev, "Irradiation of the AFIP-6 MKII Experiment in the ATR," TEV-1330, Rev 0, January 2012.

7. P. E. Murray, "Validation of ABAQUS Standard 6.7-3 Heat Transfer", ECAR-131, January 2008.

8. R. H. Perry, D. W. Green, "Perry's Chemical Engineer's Handbook," $7^{\text {th }}$ Edition, McGraw-Hill, 1997.

9. G. A. Roth, "As-Run Thermal Analysis for the AFIP-6 MKII Experiment Irradiated in the Center Flux Trap of the ATR, Cycle 151A," ECAR-XXXX, July 2012. 


\section{Appendix A: \\ Individual Plate Power and Fission Density Plots}




\section{Top of Plate 6II-1}

(MCNP node 1)

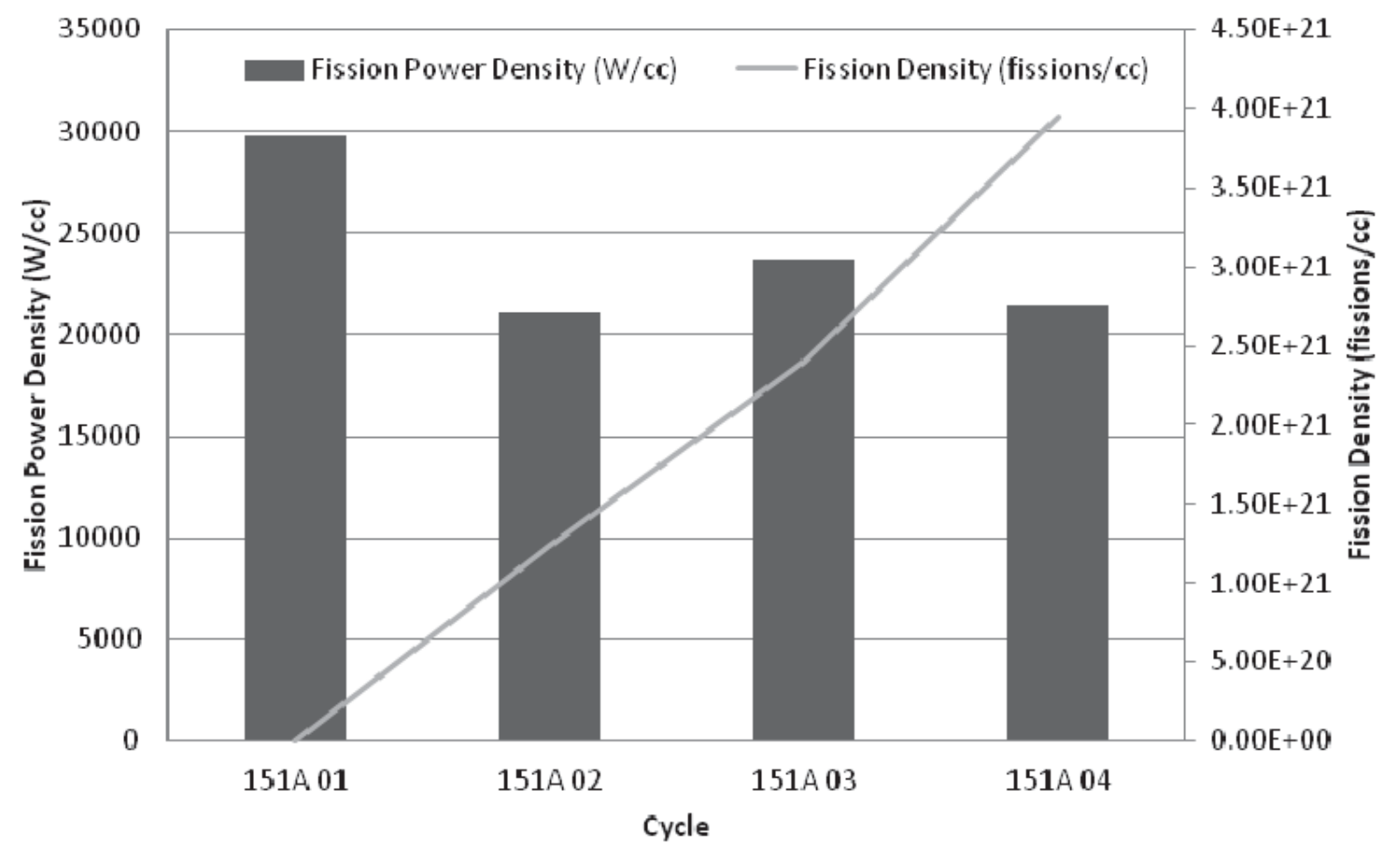

Middle of Plate 6II-1

(MCNP node 23)

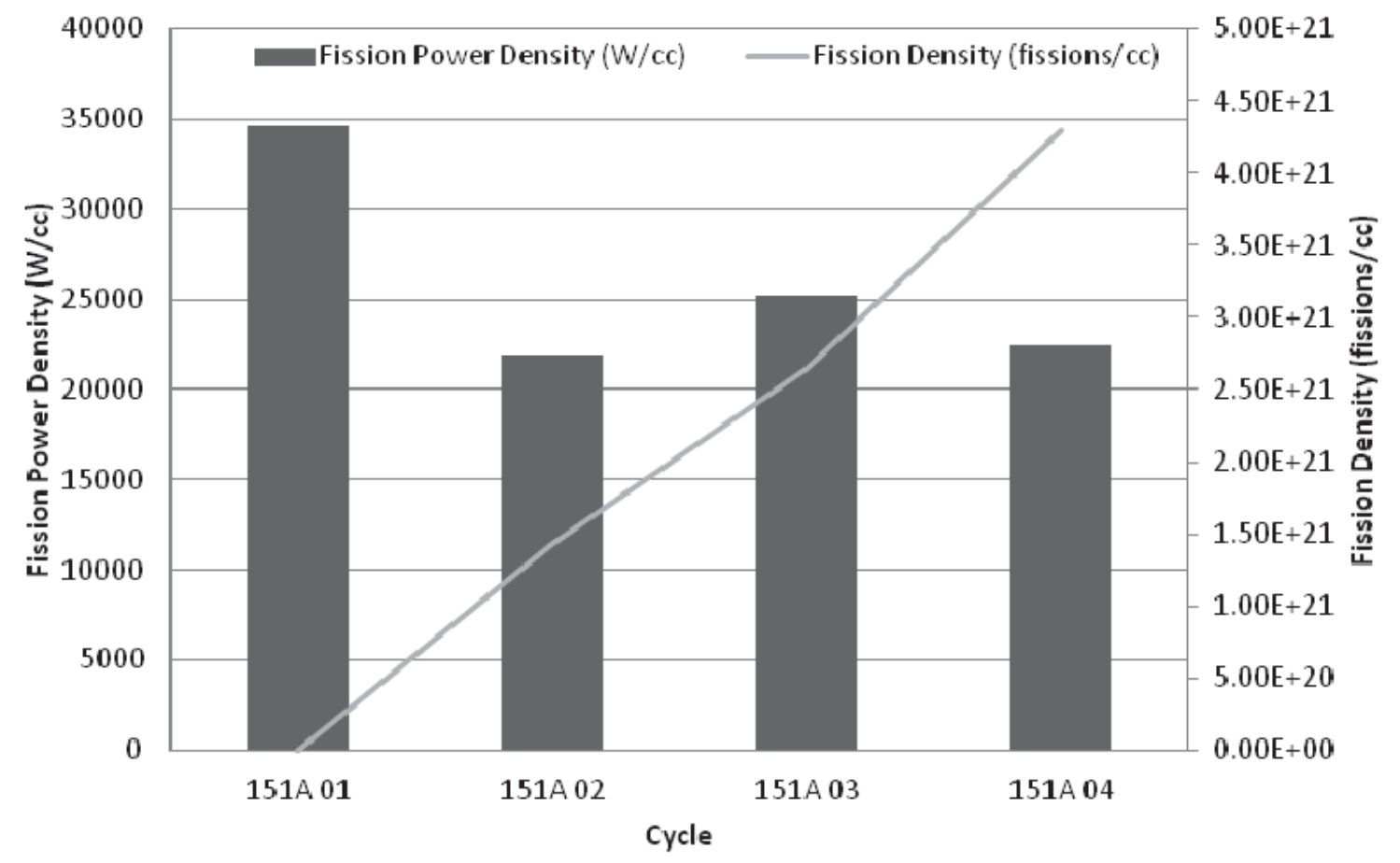




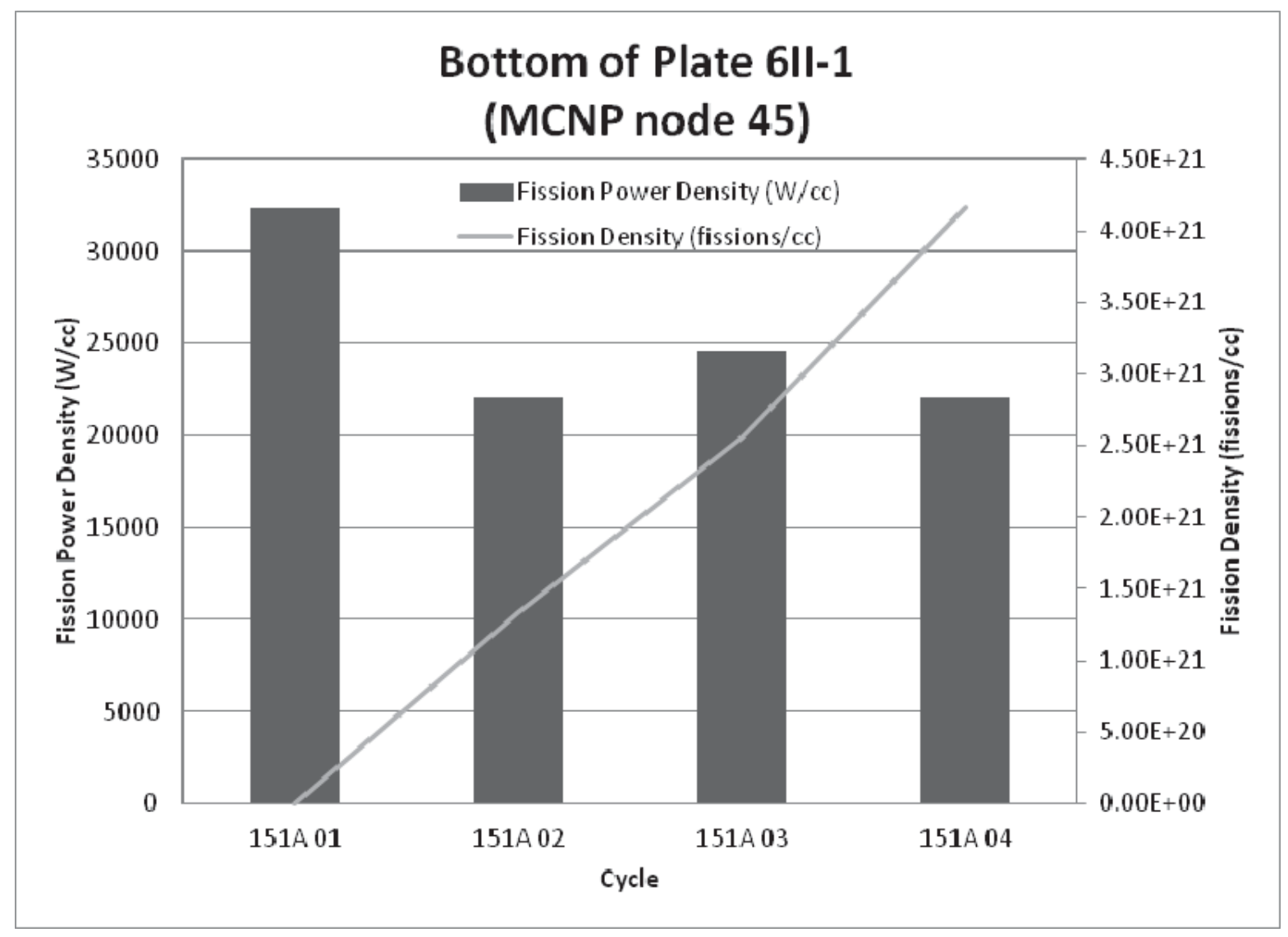

